\author{
UNIVERSIDADE DE SÃO PAULO \\ FACULDADE DE MEDICINA DE RIBEIRÃO PRETO \\ Departamento de Neurociências e Ciências do Comportamento
}

LINCOLN DA SILVA FREITAS

ESTUDO ANATÔMICO DO TRONCO ENCEFÁLICO POR IMAGENS DE RESSONÂNCIA MAGNÉTICA DE 3 TESLAS E CORRELAÇÃO COM CORTES HISTOLÓGICOS

RIBEIRÃO PRETO - SP

2016 


\title{
ESTUDO ANATÔMICO DO TRONCO ENCEFÁLICO POR IMAGENS DE RESSONÂNCIA MAGNÉTICA DE 3 TESLAS E CORRELAÇÃO COM CORTES HISTOLÓGICOS
}

\author{
Dissertação apresentada à \\ Faculdade de Medicina de Ribeirão \\ Preto da Universidade de São Paulo \\ para a obtenção do título de Mestre \\ em Ciências.
}

Área de Concentração:

Neurologia

Sub-área: Neurociências

Orientadora: Prof ${ }^{a}$. Dra ${ }^{\text {a }}$. Valéria Paula Sassoli Fazan

Ribeirão Preto - SP

2016 


\section{AUTORIZO A REPRODUÇÃO E DIVULGAÇÃO TOTAL OU PARCIAL DESTE TRABALHO, POR QUALQUER MEIO CONVENCIONAL OU ELETRÔNICO, PARA FINS DE ESTUDO E PESQUISA, DESDE QUE CITADA A FONTE.}

Catalogação na Publicação

Serviço de Documentação

Faculdade de Medicina de Ribeirão Preto

\section{Freitas, Lincoln da Silva.}

Estudo anatômico do tronco encefálico por imagens de ressonância magnética de 3 Teslas e correlação com cortes histológicos / Lincoln da Silva Freitas; orientadora Valéria Paula Sassoli Fazan.

--Ribeirão Preto, 2016.

124 págs, 43 ilustrações.

Dissertação (Programa de Pós-graduação em Medicina - Área de Concentração: Neurologia/ Neurociências ) - Faculdade de Medicina de Ribeirão Preto da Universidade de São Paulo.

1) Tronco encefálico; 2) Estudo Anatômico do tronco encefálico ; 3) Imagem de Ressonância Magnética.4) Cortes histológicos do tronco encefálico 


\title{
FOLHA DE APROVAÇÃO
}

\author{
Lincoln da Silva Freitas
}

\section{Estudo anatômico do tronco encefálico por imagens de ressonância magnética de 3 Teslas e correlação com cortes histológicos}

Dissertação apresentada à Faculdade de Medicina de Ribeirão Preto da Universidade de São Paulo para a obtenção do título de Mestre.

Área de Concentração: Neurologia

Aprovado em:

BANCA EXAMINADORA:

Prof.Dr.

Instituição:

Assinatura:

Prof.Dr.

Instituição:

Assinatura:

Prof.Dr

Instituição:

Assinatura: 


\section{DEDICATÓRIA}

Dedico esta obra a meus pais, Luiz Almeida Freitas (in memoriam) e Maria da Silva Freitas, pelo apoio, carinho, compreensão e incentivo, sem os quais eu não teria trilhado este caminho.

A minha irmã Margareth, pela força e apoio incondicionais.

A minha esposa Renata por estar comigo em todos os momentos me dando força, sempre muito paciente e pronta a me ajudar.

As minhas filhas Carol e Gabi pelo carinho, amor e paciência.

A minha querida orientadora Profa. Dra. Valéria Fazan sem a qual não conseguiria a realização deste trabalho com sua paciência, interesse e amor pelos seus alunos.

Ao Coordenador da Pós-Graduação, Prof. Dr. João Pereira Leite e a todos os professores Departamento de Neurologia.

Ao Prof. Dr. Antônio Carlos Santos pela sua inestimável contribuição na realização deste trabalho.

À Silvana Loturco por todo apoio e preciosa ajuda.

Ao Jeam Haroldo Oliveira Barbosa, pós graduando do Departamento de Física da USP Ribeirão Preto, por sua imprescindível contribuição na aquisição das imagens de ressonância magnética.

À Elisabete de Cássia do Carmo, doutoranda em Neurociências do Departamento Neurociências e Ciências do comportamento da USP Ribeirão Preto, pela ajuda e força nos momentos mais difíceis da realização deste trabalho, o meu profundo agradecimento.

Aos membros da banca examinadora e membros suplentes, pelo gentil aceite de participação na banca, assim como as valiosas contribuições para com este trabalho.

E por fim, a todos aqueles que acreditaram e acreditam no meu trabalho e que direta ou indiretamente contribuíram para que este fosse concluído. 


\section{Epigrafa}

"A única maneira de fazer um grande trabalho é amar o que se faz. Se você ainda não encontrou o seu, continue procurando. E não descanse enquanto não achar"

Steve Jobs 


\section{RESUMO}

Freitas,L.S. Estudo anatômico do tronco encefálico por imagens de ressonância magnética de 3 Teslas e correlação com cortes histológicos 2016.124 Páginas. Dissertação (Mestrado). Faculdade de Medicina de Ribeirão Preto, Universidade de São Paulo, Ribeirão Preto, 2016.

O Tronco encefálico é uma estrutura singular do sistema nervoso central, pois nele passam tratos sensoriais ascendentes da medula espinal, tratos sensoriais da cabeça e do pescoço, os tratos descendentes motores originados no prosencéfalo, as vias ligadas a centros de movimento dos olhos, contemos núcleos dos nervos cranianos, e também está envolvido na regulação do nível de consciência através de projeções ao prosencéfalo oriundas da formação reticular. Tudo isto compactado em um espaço muito exíguo o que faz deste um local particularmente sensível às alterações patológicas, mesmo que pequenas, que acabam cursando com uma riqueza de sinais neurológicos devido a presença muito próxima das estruturas já citadas. Compreender a anatomia interna do tronco encefálico é essencial para o diagnóstico neurológico e a prática da medicina clínica. Por tudo que foi exposto, o tronco encefálico é um terreno fértil para o estudo através do diagnóstico por imagem, principalmente quando realizado por novas tecnologias, como exames em aparelho de ressonância magnética de alto campo ( 3 teslas). No entanto, pouco se sabe sobre as correlações existentes entre a microscopia e as imagens de ressonância magnética do tronco encefálico. Sendo assim, o objetivo deste estudo foi analisar e correlacionar as diversas estruturas encontradas no tronco encefálico, visualizadas em peças microscópicas de encéfalos humanos post mortem, com as imagens de ressonância magnética dos mesmos, antes da dissecção, mapeandoas e discernindo-as, contribuindo assim para diagnósticos mais precisos e topográficos das patologias que acometem o tronco encefálico, justificando o presente estudo. O estudo foi de caráter observacional exploratório e descritivo, adotando as seguintes técnicas para coleta da informações: os encéfalos humanos $(n=3)$ foram submersos em recipiente contendo água e então lacrados de forma que $o$ ar ambiente não entrasse no recipiente. As imagens de RM foram adquiridas em sequência gradiente echo (FFE) 2D em equipamento de campo 3T (PHILIPS ACHIEVA), com bobina de 8 canais de encéfalo. Foi utilizado $\mathrm{TE}=9,0 \mathrm{~ms}, \mathrm{TR}=1000 \mathrm{~ms}$ e o ângulo de flip $90^{\circ}$; número de médias igual 10 e BW por pixel igual a $72 \mathrm{~Hz} /$ pixel. O Fator EPI utilizado foi igual a um e a resolução espacial de $0,219 \times 0,219 \times 2,0 \mathrm{~mm}^{3}$ com FOV de $210 \times 210 \times 90 \mathrm{~mm}^{3}$. O tempo total de aquisição foi de 3 horas e 01 minuto e 96 segundos. Imagens histológicas utilizadas no presente estudo são do banco de dados do departamento de patologia da UNICAMP e foram comparadas às imagens obtidas na ressonância magnética. Demonstramos que foi possível a identificação das estruturas visíveis, histologicamente, nas imagens obtidas, com definição e resolução suficiente para a geração de um atlas de imagens de ressonância magnética de cortes do tronco encefálico.

Palavras-chaves: Tronco encefálico, Estudo Anatômico do tronco encefálico, Imagem de Ressonância Magnética, Tratos e núcleos. 


\begin{abstract}
Freitas,L.S. Anatomical study of brainstem magnetic resonance images of 3 Teslas and correlation with histological sections 2016,124 pages. Thesis (MS). Faculty of Medicine of RibeirãoPreto, University of São Paulo, RibeirãoPreto, 2016.
\end{abstract}

The Brainstem is a unique structure of the central nervous system, because in it pass ascending sensory tracts of the spinal cord, sensory tracts of head and neck, descending tracts originated in the forebrain, the pathways linked to eye movement centers, contains nuclei of cranial nerves, and is also involved in regulating the level of consciousness through projections to the forebrain that arise from the reticular formation. All these estructures are packed into a very small space which makes the brainstem a particularly sensitive place to pathological changes, that bring up a large amount of neurological signs due to very close packing of the aforementioned structures. Understanding the internal anatomy of the brainstem is essential for the neurological diagnosis and the clinical medicine practice. Thus, the brainstem is fertile ground for the study through diagnostic imaging, especially when performed by new technologies such as high-field ( 3 tesla) MRI machines. However, little is known about the correlation between the microscopy and magnetic resonance imaging of the brainstem. The aim of this study was to analyze and correlate the various structures found in the brainstem, viewed in microscopic slides of human brains post mortem, with the magnetic resonance imaging thereof, prior to dissection, mapping them and defining them, thus contributing to more accurate diagnoses and surveying of pathologies that affect the brainstem. Human brains $(n=3)$ were submerged in a container containing water, and then sealed so that the ambient air does not enter the container. MRI images were acquired in gradient echo sequence (FFE) 2D 3T field equipment (PHILIPS ACHIEVA) with coil 8channel brain. It was used TE $=9.0 \mathrm{~ms}, \mathrm{TR}=1000 \mathrm{~ms}$ and flip angle $90^{\circ}$; number of averages equal to 10 and BW per pixel equal to $72 \mathrm{~Hz} /$ pixel. Factor PPE used was equal to one and the spatial resolution of FOV with $0,219 \times 0,219 \times 2,0 \mathrm{~mm}^{3} 210 \times 210 \times 90 \mathrm{~mm}^{3}$. The total acquisition time was 3 hours, 01 minute and 96 seconds. Histological images used in this study are from the pathology department of State University of Campinas (UNICAMP) database and compared to images obtained in MRI. We demonstrated that it was possible to identify histologically visible structures in images acquired with sufficient resolution and definition to generate an magnetic resonance imaging atlas of the brainstem sections.

Keywords: Brainstem, Anatomical Study of the brainstem,magnetic resonance imaging, tracts and nuclei 


\section{LISTA DE FIGURAS}

Figura 01

Figura 02

Figura 03

Figura 04

Figura 05

Figura 06

Figura 07

Figura 08

Figura 09

Figura 10

Figura 11

Figura 12

Figura 13

Figura 14

Figura 15

Figura 16

Figura 17

Figura 18

Figura 19

Figura 20

Figura 21

Figura 22

Figura 23

Figura 24

Figura 25

Figura 26

Figura 27

Figura 28

Figura 29

Figura 30
Desenvolvimento do tronco encefálico.

Face anterior do tronco encefálico...

21

Face posterior do tronco encefálico.

Corte axial do bulbo no nível das pirâmides e núcleos grácil e

cuneiformes

Corte axial do bulbo evidenciando os núcleos da coluna posterior

Corte axial do bulbo no nível dos núcleo olivares inferiores.

Corte axial do bulbo no nível dos pedúnculos cerebelares inferior

Corte axial no nível da transição bulbo pontina.

Imagem de RM ponderada em T2 axial do bulbo

evidenciando infarto medial direito

Imagem de RM ponderada em T1 e T2 axial do bulbo

evidenciando infarto lateral direito

Peça anatômica úmida da face anterior da ponte e

mesencéfalo

Peça anatômica úmida da face posterior da ponte e

bulbo.

Corte axial microscópico da

ponte.

Corte axial da ponte evidenciando o tegmento

A) IRM axial da ponte ponderada em T1 B )IRM axial da ponte ponderada em T2 evidenciando área de infarto na parte ventral esquerda (Síndrome de Millard-Gluber)....

IRM FLAIR axial do tronco encefálico no terceiro dia de hospitalização.

a) IRM axial difusão. b) Axial T2 evidenciando área de infarto pontino ántero inferior.

Peça úmida da face antero-lateral do mesencéfalo e ponte.

68

Corte histológico axial do terço inferior do mesencéfalo.

Corte axial histológico do mesencéfalo no nível do colículo superior

Corte axial da histológico da transição mesencéfalo-

diencéfalo

IRM, A) Axial FLAIR, B) Axial difusão do mesencéfalo evidenciando área de infarto medialmente esquerda.

IRM, A) Axial T2, B) Axial GRE evidenciando área hemorrágica pós-

traumática envolvendo o mesencéfalo lateralmente a

direita.

IRM, A e C) Axial T2, B) Axial difusão evidenciando área de infarto na

metade medial do núcleo rubro direito

IRM, A ) Axial T2, B) Axial difusão evidenciando área de

infarto medialmente no mesencéfalo (Plus MinusLidSyndrome)

A) axial, e B) coronal T1 com contraste evidenciando germinoma da pineal comprimindo a lámina quadrigêmina.

IRM axial T2 Lesão em pedúnculo cerebral esquerdo (Alucinose

peduncular).

Recipiente lacrado com encéfalo para exame de imagem

Imagens de correlação entre IRM e corte histológico do bulbo no nível das pirâmides.

Imagens de correlação entre IRM e corte histológico do bulbo no nível dos núcleos olivares inferiores. 
Figura 31 Imagens de correlação entre IRM e corte histológico do bulbo no nível dos núcleos olivares inferiores.......................................................... 101

Figura 32 Imagens de correlação entre IRM e corte histológico da ponte................. 102

Figura 33 Imagens de correlação entre IRM e corte histológico da ponte evidenciando detalhes do seu tegmento...................................... 103

Figura 34 Imagens de correlação entre IRM e corte histológico do mesencéfalo no nível dos colículos inferiores.............................................................. 104

Figura 35 Imagens de correlação entre IRM e corte histológico do mesencéfalo no nível dos colículos superiores...................................... 105

Figura $36 \quad$ Imagens de correlação entre IRM e corte histológico da transição mesencéfalo-diencéfalo.

Figura 37 Atlas de Imagens de Ressonância Magnética de Alta resolução do bulbo no nível das pirâmides.

Figura 38 Atlas de Imagens de Ressonância Magnética de Alta resolução da transição bulbo pontino.

Figura 39 Atlas de Imagens de Ressonância Magnética de Alta resolução da transição bulbo pontinho.

Figura 40 Atlas de Imagens de Ressonância Magnética de Alta resolução da ponte, com detalhes do tegmento.

Figura 41 Atlas de Imagens de Ressonância Magnética de Alta resolução do Mesencéfalo no nível do colículo inferior.

Figura 42 Atlas de Imagens de Ressonância Magnética de Alta resolução do Mesencéfalo no nível do colículo superior.

Figura 43 Atlas de Imagens de Ressonância Magnética de Alta resolução da transição mesencéfalo diencéfalo. 


\section{LISTA DE ABREVIATURAS}

$\begin{array}{ll}\text { FLAIR } & \text { Fluidattenuationinversionrecovery } \\ \text { FLM } & \text { Fascículo Longitudinal Medial } \\ \text { IRM } & \text { Imagem por Ressonância Magnética } \\ \text { RM } & \text { Ressonância Magnética } \\ \text { TE } & \text { Tronco Encefálico } \\ \text { T1 } & \text { Primeiro tempo de eco } \\ \text { T2 } & \text { Segundo tempo de eco } \\ \text { SNC } & \text { Sistema Nervoso Central } \\ \text { FS } & \text { Fascículos } \\ \text { NC I } & \text { Nervo Craniano I } \\ \text { GSE } & \text { Núcleo Motor Eferente Somático } \\ \text { SVE } & \text { Núcleo Eferente Especial Visceral } \\ \text { GVE } & \text { Núcleo Eferente Visceral Especial } \\ \text { GVA } & \text { Núcleo Aferente Visceral Geral } \\ \text { SVA } & \text { Núcleo Aferente Somático } \\ \text { NAS } & \text { Núcleo Aferente Visceral Especial } \\ \text { REM } & \text { RapidEyeMoviment } \\ \text { TR } & \text { Tratos } \\ \text { SB } & \text { Substância Branca } \\ \text { SC } & \text { Substância Cinzenta } \\ \text { LCR } & \text { Liquido Cefalorraquidiano } \\ \text { FOV } & \text { Fildofview } \\ \text { RF } & \text { Radiofrequência } \\ \text { SE } & \text { Spin Echo } \\ \text { GRE } & \text { Gradiente Echo } \\ \text { NUC } & \text { Núcleos } \\ \text { TR } & \text { Tempo de Repetição } \\ & \end{array}$




\section{SUMÁRIO}

INTRODUÇÃO.

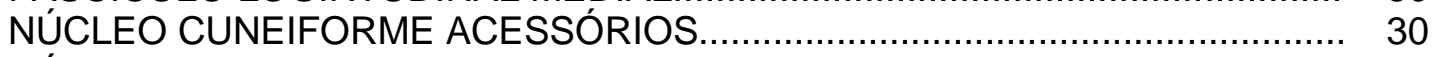

2.9

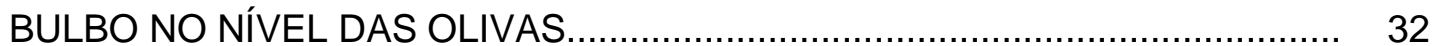

Sindrome bulbar medial

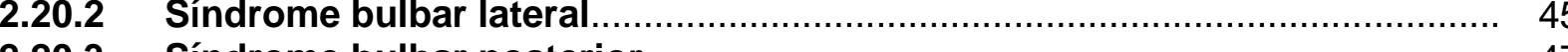

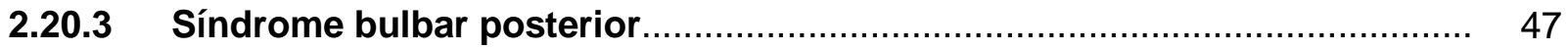

2.20.4 Paralisia pseudo bulbar......................................................................... 48

3.1 DESENVOLVIMENTO

P.2 PLACAS ALAR E BASAL .................................................................. 49

3.3

ASPECTOS MACROSCÓPICOS DA PONTE.

3.4

3.5

3.6

3.6.1 ASPECTOS MICROSCÓPICOS DA PONTE. TEGMENTO DA PONTE.

3.7.1 NERVO FACIAL (VII NERVO CRANIANO).

3.8 NERVO ABDUCENTE (VI NERVO CRANIANO) ........................................... 63

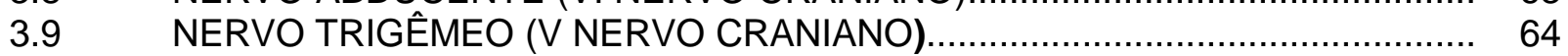

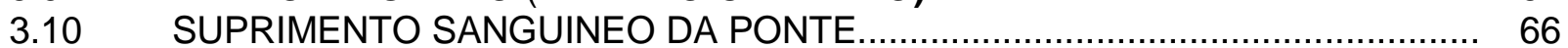

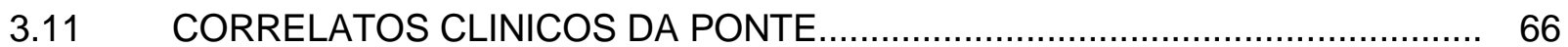

3.11.1 Síndromes pontinhas basilares............................................................ 66

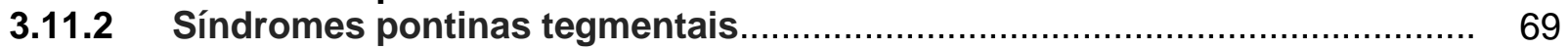

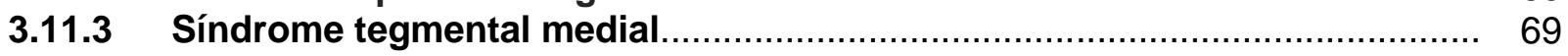

3.11.4 Síndrome pontina tegmental póstero-lateral...................................... 69 
inferiores

3.11.6 Síndrome pontina tegmental média (síndrome de

Grenet).

3.11.7 Síndrome pontina tegmental lateral (Síndrome de Marie-

Foix).

PONTE E RESPIRAÇÃO

$4 \quad$ ANATOMIA DO TRONCO ENCEFÁLICO (MESENCÉFALO) ...................... 72

4.1 DESENVOLVIMENTO DO MESENCÉFALO ........................................... 72

4.2 ASPECTOS MACROSCÓPICOS DO MESENCÉFALO .................................. 73

4.3 ASPECTOS MICROSCÓPICOS DO MESENCÉFALO .................................. 74

4.3.1 Organização geral........................................................................... 74

4.3.2 Estruturas no nível do colículo inferior................................................. 75

4.3.3 Tegmento do mesencéfalo.......................................................................... 76

4.3.4 Parte basilar do mesencéfalo............................................................. 78

4.3.5 Substância Cinzenta Central (Periaquedutal) ...................................... 83

4.3.6 Formação reticular mesencéfalo...................................................... 84

4.4 SUPRIMENTO SANGUÍNEO DO $\quad 85$

4.5 CORRELATOS CLINICOS DO MESENCÉFALO...................................... 86

4.5.1 Síndromes vasculares mesencéfalos ..................................................... 86

4.5.2 Síndromes de Weber............................................................................ 87

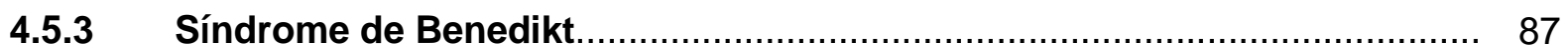

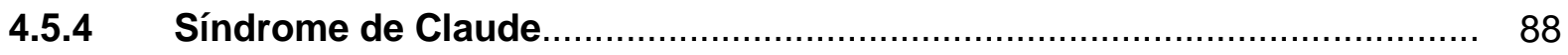

4.5.5 Síndrome plus-minus palpebral....................................................... 89

4.5.6 Síndrome de Parinaud .................................................................... 90

4.5.7 Síndrome do alucinose peduncular................................................... 91

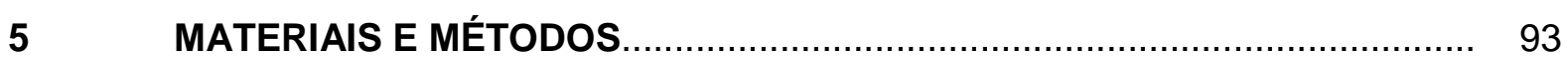

5.1 CARACTERIZAÇÃO DA PESQUISA........................................................ 94

$5.2 \quad$ PROCEDIMENTOS PARA COLETA DE DADOS .......................................... 94

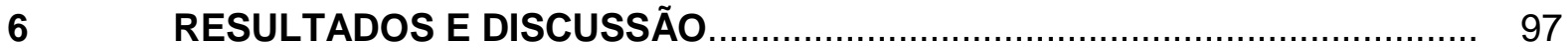

6.1 CORRELAÇÃO IMAGENS HISTOLÓGICAS versus IMAGENS DE RM......... 98

6.2 ATLAS DE IMAGENS DE RESSONÂNCIA MAGNÉTICA DE ALTA RESOLUÇÃO DE CORTES MICROSCÓPICOS DO TRONCO ENCEFÁLICO.

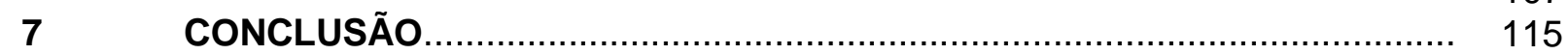

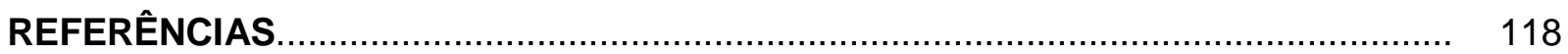

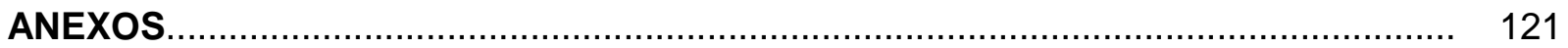


INTRODUÇÃO 


\section{INTRODUÇÃO}

O rápido crescimento e evolução das tecnologias da informação e da comunicação (TICs) e sua aplicação no diagnóstico por imagem, sobretudo da Ressonância Magnética, tem permitido aos médicos especialistas diferentes tipos de estudos de diagnósticos clínicos.

As investigações com ressonância magnética se iniciaram nos laboratórios de física nas primeiras décadas do século XIX nas universidades americanas. Durante a década de 1930, Isodor Isaac Rabi e sua equipe de cientistas da Universidade de Columbia nos EUA desenvolveram a ressonância magnética de feixes moleculares como técnica para estudar as propriedade magnéticas e a estrutura interna das moléculas, dos átomos e dos núcleos, o resultado deste trabalho científico outorgou o Prêmio Nobel de Física, em 1944, ao cientista Rabi.

As investigações com ressonância magnética seguiram avançando durante as décadas seguintes do século XX. O cientista inglês Godfrey Newbold Hounsfield compartilhou com o cientista sulafricano Allan M. Comarck, em 1970, o Prêmio Nobel de fisiologia em medicina pelo desenvolvimento da tomografia computadorizada, de modo que os princípios da tomografia computadorizada constituem um dos métodos precisos para obtenção de imagens na atualidade.

Transcorreram décadas, até que Paul Lauterbur, em 1972, propôs a obtenção de imagens de estrutura de tecidos baseadas na ressonância magnética. Nos princípios da década de 1980, várias as pesquisas relacionadas a obtenção de imagens por ressonância magnética passam a ser desenvolvidas em seus aspectos comerciais. Os avanços no campo da informática de alta velocidade e supercondutores permitiram aos pesquisadores desenhar máquinas de ressonância magnética com sensibilidade e resoluções de alta precisão. (THE NATIONAL ACADEMIES, 2015).

De fato, a Ressonância Magnética é uma técnica de diagnóstico essencial para todos os processos, bem como das funções do cérebro e do sistema nervoso central. As imagens desta técnica são capazes de fornecer resoluções anatômicas equivalente a uma resolução de contraste superiores àquelas emitidas por meio de raios $\mathrm{X}$ e de escaneres da Tomografia Computadorizada. 
$\mathrm{Na}$ literatura científica, Naidich e Cols (2008) foram capazes de identificar algumas imagens com excelente resolução do tronco encefálicoatravés da visualização submilimétrica, entretanto estas foram obtidas com aparelhos de 7 ou 9 teslas e com softwares especializados, e consequentemente custos muito elevados.

O tronco encefálico é formado pelo bulbo (medula oblonga), ponte e mesencéfalo e está localizado na fossa craniana posterior, limita-se posteriormente com o cerebelo e anteriormente com o clívus, superiormente se conecta ao diencéfalo e inferiormente com a medula espinhal (SNELL et al., 2010). O estudo por imagens de ressonância magnética do tronco encefálico é de grande valia para a identificação das diversas estruturas nele encontradas, auxiliando os neurorradiologistas, os neurologista e os neurocientistas no estudo anatômico, bem como no diagnóstico das diversas patologias que acometem esta região do sistema nervoso central.

Nesta perspectiva, a pergunta que norteia nossa pesquisa é a seguinte: como obter imagens semelhantes com os aparelhos até então disponíveis em nosso país? Mais precisamente, as imagens de ressonância magnética são capazes de visualizar estruturas submilimétricas e com que acuracidade?

Por conseguinte, uma hipótese central levantada consiste que a obtenção de imagens tão precisas quanto a destes aparelhos aumentando o tempo de aquisição e mudando alguns parâmetros na aquisição normal da imagem de RM, utilizando peças úmidas de encéfalo humano.

Portanto, os objetivos dessa pesquisa são:

a) Identificar e estudar por meio de imagens de ressonância magnética as estruturas microscópicas do tronco encefálico, como núcleos, tratos, fascículos e lemniscos, com as técnicas de alta resolução;

b) Correlacionar as referidas imagens com os cortes histológicos mostrando a fidedignidade das imagens de ressonância magnética com a histologia.

c) Confeccionar um atlas de microscopia do tronco encefálico com cortes de ressonância magnética e cortes histológicos correlacionados.

O presente trabalho encontra-se estruturado da seguinte forma: na primeira seção, Introdução, destinamos a apresentação da proposta central subjacente a esta pesquisa.

$\mathrm{Na}$ segunda seção, destinamos ao levantamento e realização da literatura sobre o tema estrutura anatômica do tronco encefálico, esta seção foi subdividida em 
três capítulos respectivamente: Capitulo 2-Bulbo (medula oblonga); Capítulo 3Anatomia da Ponte; Capítulo 4-Mesencéfalo. Já no capítulo 5, foram apresentados o método inerente ao estudo, bem como os procedimentos técnicos para a realização da coleta de informações (imagens).

No capitulo 6, destinamos a realização dos resultados e da discussão destes e, especialmente, a produção do Atlas do Tronco Encefálico com Cortes de Ressonância Magnética e Cortes Histológicos Correlacionados. Finalmente, no capítulo 7, destinamos as conclusões e principais impressões obtidas mediante esta pesquisa. 
ReVIsão da Literatura ANATOMIA DO TRONCO ENCEFÁLICO 


\section{ANATOMIA DO TRONCO ENCEFÁLICO ( BULBO )}

A estrutura básica do bulbo é advinda de um plano estrutural semelhante aquele visto na medula espinal. As placas basal e alar originam núcleos específicos e a camada do manto circunjacente é invadida por axônios que se originam em outros níveis.

Os neurônios em amadurecimento da placa basal do bulbo dão origem ao núcleo do hipoglosso, ao núcleo motor dorsal do vago e ao núcleo salivatório inferior e ao núcleo ambíguo. Caudalmente ao óbex, todos esses núcleos estão localizados medialmente ao sulco mediano.

Os núcleos dos nervos cranianos derivados da placa alar no bulbo e seus componentes funcionais correspondentes incluem os núcleos vestibular e coclear, o núcleo do trato solitário e o núcleo trigêmeo.

Neuroblastos da placa alar caudalmente ao óbex dão origem aos núcleos grácil e cuneiforme. Rostralmente ao óbex, algumas células da placa alar migram ventral e medialmente para formar o complexo olivar inferior.

Associados a estes eventos do desenvolvimento, fibras ascendentes e descendentes estão atravessando o bulbo. Um feixe especialmente proeminente de axônios se agrupa na superfície anterior do bulbo para formar as pirâmides (HAINES et al., 2006).

Figura 1- Desenvolvimento do tronco encefálico

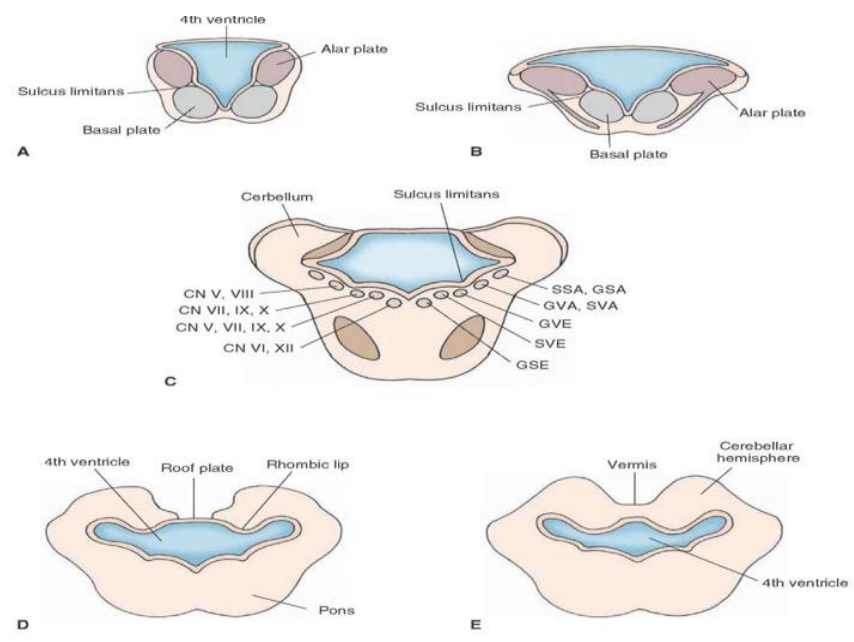

Fonte: Site Didático de Anatomia Pat., Neuropatologia e Neuroimagem (2015) 
As Figuras de $\mathrm{A}$ a $\mathrm{C}$ descrevem o desenvolvimento do tronco cerebral inferior. A organização nuclear é transformada a partir da orientação dorsal-ventral e para na medula espinal, em uma orientação medial-lateral mostrada nas figuras B e C. A figura $\mathrm{C}$ mostra como os núcleos dos nervos cranianos são organizados no tronco cerebral em sua disposição medial a lateral. Aqui, pode ser visto que os núcleos motores (GSE, SVE) estão situados medial ao sulco limitante, os núcleos sensitivos (SSA, GSA) estão localizados lateralmente ao sulco limitante, e os núcleos autonômicos (GVA, VAB, VAB) são encontrados em a região adjacente a sulco limitante. Figuras D e E representam o desenvolvimento do cerebelo. Note-se a formação e o desenvolvimento do cerebelo a partir dos lábios rômbicos que se fundem na linha média. (WHAT-WHEN-HOW, 2015).

\subsection{ASPECTOS MACROSCÓPICOS DO BULBO}

O bulbo ou medula oblonga conecta-se com a ponte superiormente e com a medula espinal inferiormente. A separação do bulbo e da medula espinal está na origem das raízes anterior e posterior do primeiro nervo espinal cervical, que corresponde, aproximadamente, ao nível do forame magno. O bulbo apresenta uma forma de um cone, e sua extremidade basal é dirigida cranialmente onde compõe a parte inferior da fossa rombencefálica ( IV ventrículo).

$\mathrm{Na}$ face anterior do bulbo localiza-se a fissura mediana anterior, que é contínua inferiormente com fissura do mesmo nome pertencente a medula espinal. Em cada lado da fissura mediana, há um abaulamento denominado de pirâmides (Fig.2). As pirâmides são compostas de feixes de fibras axonais, chamadas de tratos córticos espinhais, as quais se originam nas grandes células de Betz no giro précentral do lobo frontal do córtex cerebral.

As pirâmides afilam-se inferiormente na parte mais caudal do bulbo onde a maior parte das fibras axonais, cerca de 90\%, cruzam para o lado oposto, formando a chamada decussação das pirâmides (Fig.2). Posterolateralmente entre a fissura mediana anterior e a fissura antero-lateral observamos duas elevações ovaladas que correspondem aos núcleos olivares inferiores subjacentes (AFIFI; BERGMAN, 2005).

A fissura entre a pirâmide e a oliva emergem as radículas do nervo hipoglosso. Posteriormente, às olivas estão os pedúnculos cerebelares inferiores, que conectam o bulbo ao cerebelo. Na fissura entre a oliva e o pedúnculo cerebelar 
inferior emergem as raízes dos nervos glossofaríngeo e vago e as raízes cranianas do nervo acessório (SNELI et al., 2010).

Figura 2 -Face anterior do tronco encefálico (Modificado de Netter).

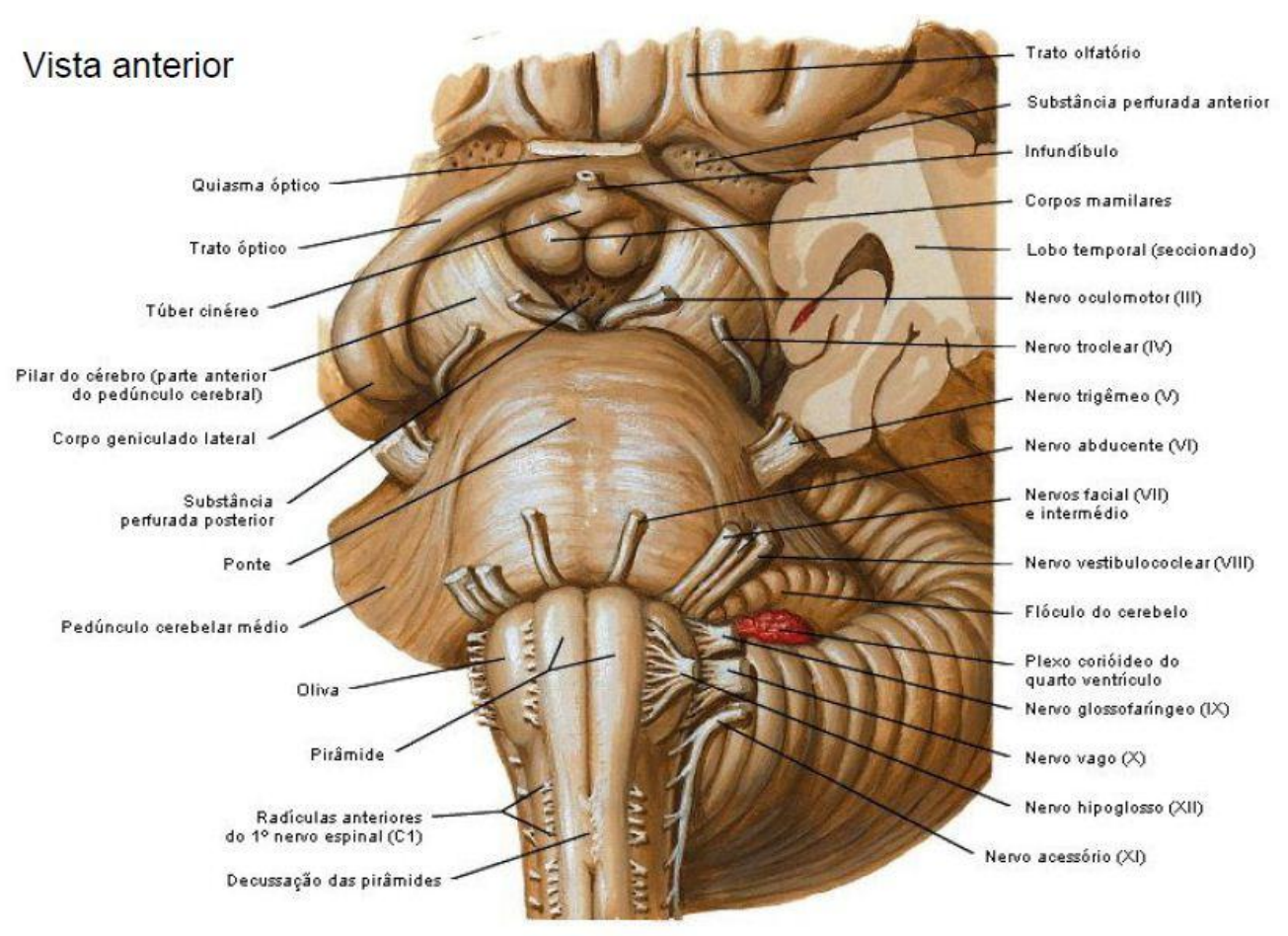

Fonte: Modificado de Netter (2005)

A metade superior da face posterior do bulbo forma a parte inferior do assoalho da fossa rombencefálica (Fig.3). A metade inferior da face posterior do bulbo é contínua com a face posterior da medula espinal, que também possui um sulco mediano posterior.

Em cada lado do sulco mediano posterior observamos uma tumefação alongada, o tubérculo grácil, produzido pelo núcleo grácil subjacente. Lateral ao tubérculo grácil há uma tumefação similar, o tubérculo cuneiforme, produzido pelo núcleo cuneiforme subjacente (AFIFI; BERGMAN, 2005). 
Figura 3-Face posterior do tronco encefálico(Modificado de Netter).

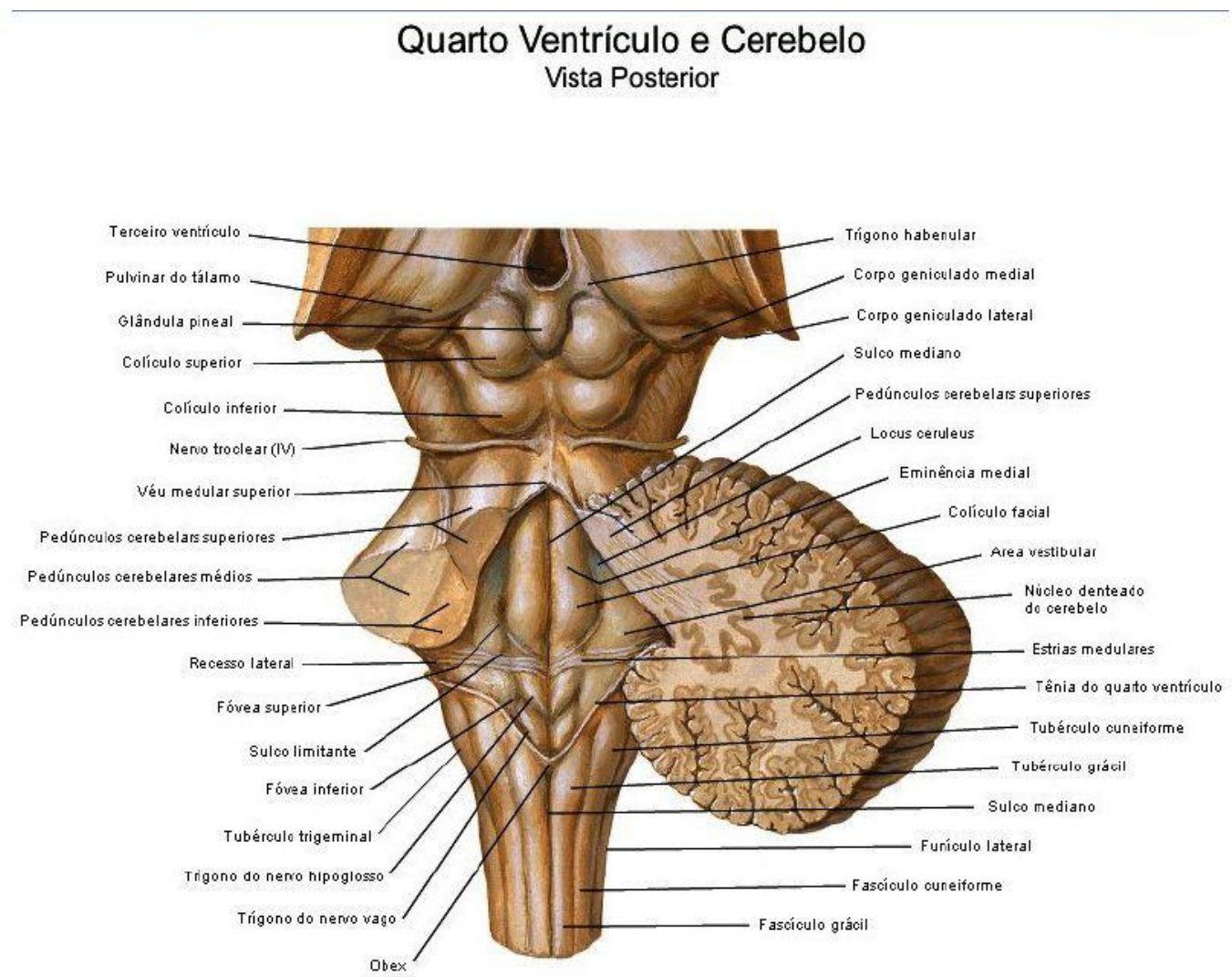

Fonte Fonte: Modificado de Netter (2005)

\subsection{ASPECTOS MICROSCÓPICOS DO BULBO}

Similarmente a medula espinal, o bulbo consiste em substância branca e cinzenta, mas um estudo minucioso com cortes transversais desta região mostra que elas foram extensamente rearranjadas.

Esse rearranjo pode ser explicado embriologicamente pela expansão do tubo neural formando a vesícula do metencéfalo, que se torna o quarto ventrículo. $A$ expansão lateral acentuada do quarto ventrículo resulta em uma alteração na posição dos derivados das lâminas alar e basal do embrião.

Podemos considerar a estrutura interna do bulbo em três níveis: (1) nível da decussação das pirâmides (decussação motora), (2) nível da decussação dos lemniscos (decussação sensitiva), (3) nível das olivas 


\subsection{BULBO NO NÍVEL DA DECUSSAÇÃO DAS PIRÂMIDES}

O conceito de controle de um lado do corpo pelo hemisfério contralateral (lei da condução cruciforme) existe desde a época de Hipócrates. O cruzamento das pirâmides não foi observado até 1790 , sendo descrito apenas no ano seguinte. No entanto, essa descrição foi ignorada e somente noticiada em 1810 por Gall e Spurzheim. Muitos anatomistas negaram a existência da decussação das pirâmides até 1835, quando Cruveilhier identificou os feixes piramidais cruzando para o lado oposto (AFIFI; BERGMAN, 2005)

As pirâmides contêm dois tipos de fibras nervosas corticais descendentes: corticoespinais e corticonucleares do bulbo. As fibras corticoespinais são organizadas somatotropicamente.

As fibras dos membros inferiores são mais laterais que as dos membros superiores. Ao descerem pelo bulbo, as fibras corticonucleares do bulbo deixam as pirâmides e se estendem aos núcleos dos nervos cranianos. Próximo à margem inferior do bulbo, cerca de 75 a $90 \%$ das fibras corticoespinais na pirâmide decussam para o lado oposto e formam o trato corticoespinal lateral (Fig. 4).

Figura 4 -Corte axial do bulbo no nível das pirâmides e núcleos grácil e cuneiformes

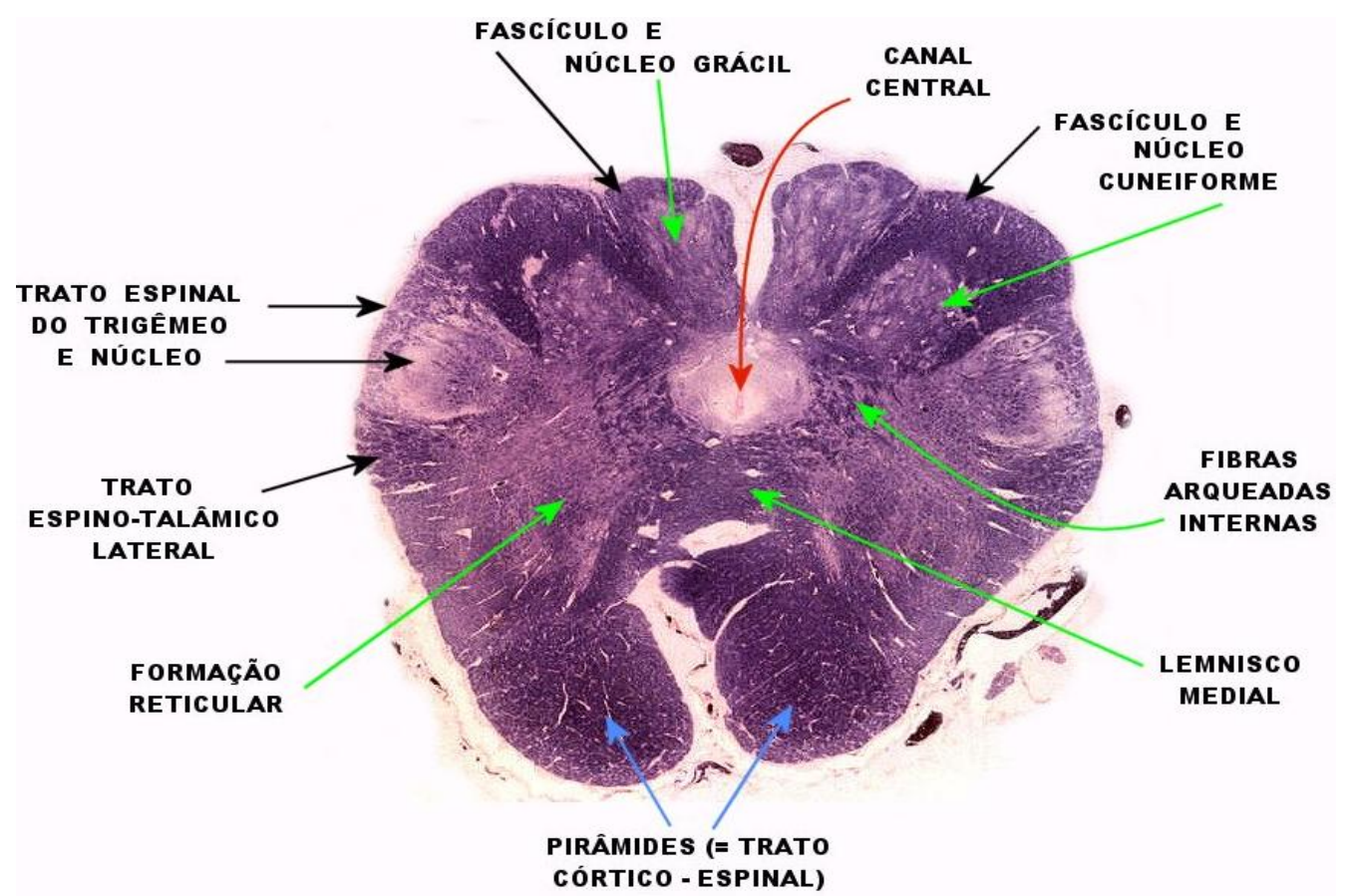

Fonte: Site Didático de Anatomia Pat., Neuropatologia e Neuroimagem (2015) 
O restante das fibras corticoespinais descem ipsilateralmente para formar 0 trato corticoespinal anterior. Foi verificado que a pirâmide esquerda decussa primeiro em $73 \%$ dos humanos; isso, entretanto não tem relação com a destreza de um indivíduo. Inicialmente cruzam as fibras corticoespinais que conduzem impulsos à musculatura do pescoço e dos membros superiores.Essas fibras são mais superiores e separadas das fibras que conduzem impulsos aos membros inferiores; também estão localizadas mais superficialmente e são identificadas na porção inferior do bulbo bem próxima ao dente do áxis (segunda vértebra cervical). Considerando sua localização, as fraturas do dente do áxis ou lesões extensas nesse local podem resultar em paralisia dos músculos dos membros superiores, podendo, porém preservar os músculos dos membros inferiores. Por outro lado, a paralisia de um membro superior ipsilateral e de um membro inferior contralateral (hemiplegia alternante) pode resultar de uma lesão na porção inferior do bulbo que danifica as fibras cruzadas para o membro superior, assim como fibras não cruzadas para o membro inferior (AFIFI; BERGMAN, 2005).

A decussação das pirâmides constitui a principal estrutura anatômica no controle voluntário de metade do corpo pelo hemisfério oposto. As fibras do fascículo longitudinal medial são deslocadas lateralmente conforme as fibras piramidais se ligam. (Figura 4)

\subsection{NÚCLEOS DA COLUNA POSTERIOR}

Dois núcleos são evidentes na coluna posterior: o núcleo grácil no fascículo grácil e o núcleo cuneiforme no fascículo cuneiforme. São conhecidos coletivamente como núcleos da coluna posterior ou dorsal. O núcleo grácil inicia e termina inferiormente ao núcleo cuneiforme. Inferiormente, podem-se notar tanto os núcleos quanto os fascículos que os recobrem, porém superiormente apenas os núcleos são observados. As projeções superficiais desses dois núcleos na face posterior do bulbo formam os tubérculos grácil e cuneiforme (Figuras 3 e 4).

Os núcleos da coluna posterior são organizados de acordo com a origem espacial das fibras aferentes. As fibras aferentes de C1 a T7 projetam-se para o núcleo cuneiforme, enquanto as fibras abaixo de T7 projetam-se para o núcleo grácil. 
Em experimentos em animais demonstrou-se que as terminações sobrepostas são mais extensas e irregulares no núcleo grácil que no cuneiforme, com menor representação terminal autônoma das raízes dorsais.

Os núcleos da coluna posterior não são massas celulares homogêneas. Eles contêm diferentes tipos células nervosas e, de acordo com a distribuição dessas células e suas conexões aferentes e eferentes, os núcleos da coluna posterior podem ser divididos em duas áreas distintas: uma região central e uma zona reticular. A região central compreende as partes inferior e média de cada núcleo. A zona reticular circunda a região central e consiste nas porções superior e mais profunda dos núcleos da coluna posterior.

A atividade nos núcleos da coluna posterior é controlada por influxos aferentes periféricos e modulada por influxos do córtex e outros centros suprasegmentares (formação reticular, núcleo caudado, e cerebelo). Em geral, a distribuição dos aferentes descendentes é restrita à zona reticular.

Os influxos aferentes periféricos de mecanorreceptores cutâneos ativados por estímulos mecânicos (tato, pressão, vibração, deslocamento do pelo) nos membros anteriores e posteriores de animais, são transmitidos à região central dos núcleos da coluna dorsal por aferentes primários dessa coluna (AFIFI; BERGMAN, 2005).

Figura 5-Corte axial do bulbo evidenciando os núcleos da coluna posterior

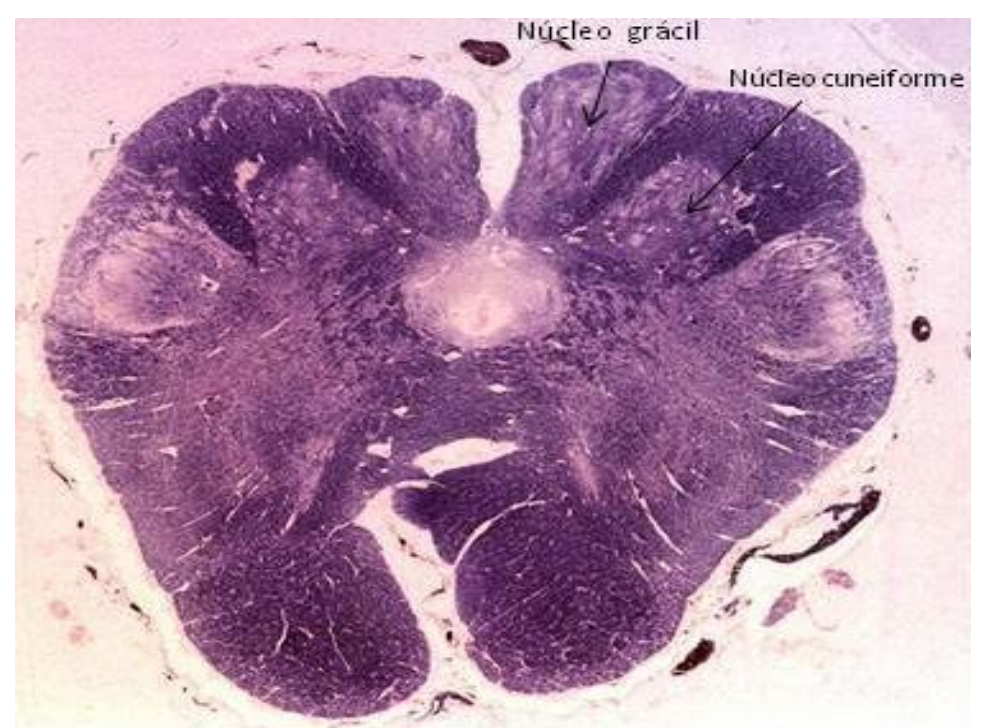

Fonte: Site Didático de Anatomia Pat., Neuropatologia e Neuroimagem (2015)

A partir desses núcleos, a informação chega ao tálamo (núcleo ventral póstero-lateral) pelo lemnisco medial. Essa via primária é responsável por cerca de 
$20 \%$ das fibras da coluna dorsal. Os ramos colaterais desses aferentes primários da coluna dorsal estabelecem sinapses com neurônios sensitivos de segunda ordem no corno posterior da medula espinhal.

Em seguida, os neurônios de segunda ordem (sensitivos) estendem-se pelo trato espinotalâmico, estabelecem sinapses com neurônios do núcleo cervical lateral, e a partir deste associam-se ao lemnisco medial para chegar ao tálamo(coluna dorsal e trato espinotalâmico), esta organização explica a preservação de sensibilidade relacionadas a esses mecanorreceptores (tato, pressão, vibração) após uma lesão da coluna dorsal.

As vias proprioceptivas originadas em receptores articulares (órgão neurotendíneo) e musculares (fuso neuromuscular) conduzem informações relacionadas ao sentido de movimento articular e posição, respectivamente e são mais complexas do que as vias originadas em mecanorreceptores cutâneos (AFIFI; BERGMAN, 2005).

Os aferentes proprioceptivos do membro superior estendem-se pela coluna posterior (fascículo cuneiforme) e estabelecem sinapses com células retransmissoras no núcleo cuneiforme e, a partir deste estendem-se pelo menisco medial até o tálamo. Por outro lado, os aferentes proprioceptivos do membro superior chegam ao tálamo por duas vias. Os aferentes oriundos de alguns receptores articulares estendem-se pela coluna posterior (fascículo grácil) ao núcleo grácil e, em seguida, projetam-se para o tálamo pelo lemnisco medial. Os aferentes oriundos dos fusos neuromusculares e dos receptores articulares de adaptação lenta abandonam o fascículo grácil e estabelecem sinapses com células do núcleo torácico posterior (de Clarke) na medula espinal.

Em seguida, os neurônios de segunda ordem estendem-se pelo fascículo póstero-lateral até o núcleo $Z$, uma pequena coleção de células situada no bulbo na parte mais superior do núcleo grácil. As fibras desse núcleo cruzam a linha mediana para compor o lemnisco medial e chegar ao tálamo, A transmissão diferencial da informação cutânea e proprioceptiva aparentemente é responsável pela diferente perda de sensibilidade vibratória e do sentido de posição em alguns pacientes com lesão da medula espinal.

Os aferentes descendentes para os núcleos da coluna dorsal originam-se principalmente do córtex somatossensitivo primário com contribuições do córtex somatossensitivo secundário e dos córtices motor primário e pré-motor. Esse influxo 
é organizado somatotopicamente de forma que áreas corticais dos membros superiores projetam-se para o núcleo cuneiforme e as áreas corticais dos membros inferiores projetam-se para o núcleo grácil. Os aferentes corticais para os núcleos da coluna dorsal estendem-se via cápsula interna e chegam aos núcleos pela pirâmide. Eles se projetam para os interneurônios da zona reticular.

A ativação de aferentes descendentes oriundos do córtex geralmente inibe, através de interneurônios, a excitação de neurônios retransmissores.

A principal projeção eferente dos núcleos da coluna posterior é o lemnisco medial, que termina no tálamo. Outras projeções, recentemente confirmadas, incluem as do complexo olivar inferior, teto mesencefálico, medula espinhal e cerebelo. As fibras cerebelares originam-se principalmente do núcleo cuneiforme com pequenas contribuições do núcleo grácil. A função dessas conexões extratalámicas ainda não é bem compreendida (AFIFI; BERGMAN, 2005).

\subsection{NÚCLEO ESPINHAL DO NERVO TRIGÊMEO}

Outra estrutura observada no nível da decussação das pirâmides é a presença do núcleo espinhal do nervo trigêmeo(Fig. 6). Esse núcleo ocupa uma posição póstero lateral no bulbo e é recoberto pelo trato espinhal (descendente) do nervo trigêmeo. O núcleo espinhal do nervo trigêmeo estende-se por todo bulbo e desce até o segmento medular de C3. Inferiormente, é contínuo com a substância gelatinosa da medula espinal e superiormente com o núcleo principal do trigêmeo na ponte. $\mathrm{O}$ trato e o núcleo espinhal do trigêmeo estão relacionados a sensibilidade exteroceptivas (dor, temperatura, tato leve) da metade ipsilateral da face.

O núcleo espinhal é dividido em três partes ao longo de sua extensão rostrocaudal (súpero-inferior). A parte caudal (núcleo caudal) estende-se superiormente do óbex do bulbo à substância gelatinosa da medula espinal, com a qual é contínua inferiormente. É responsável pela mediação de dor e temperatura da metade ipsilateral da face. Superiormente ao óbex está o núcleo interpolar, que medeia a dor dental e é citologicamente distinto do núcleo caudal. Superiormente ao núcleo interpolar e imediatamente inferior ao núcleo principal do nervo trigêmeo há o núcleo oral, que medeia sensibilidade tátil da túnica mucosa (AFIF; BERGMAN, 2005). 
As fibras do trato espinhal do nervo trigêmeo que se originam da região mandibular da face projetam-se inferiormente para o terceiro e quarto segmentos cervicais. As fibras oriundas da região perioral projetam-se para níveis medulares inferiores. Fibras que se originam entre a região mandibular e perioral terminam na região cervical superior. A evidência para este padrão de distribuição em "casca de cebola" é encontrada em pacientes que tiveram o trato espinhal do nervo trigêmeo seccionado (tratotomias) para aliviar a dor. Consequentemente as tratotomias que não atingem a parte inferior do bulbo conservam a sensibilidade térmica e dolorosa ao redor da boca. Em contraste com o padrão de distribuição em casca de cebola descrito por Dejerine em 1914, algumas observações sugerem que todas as fibras que conduzem impulsos dolorosos da face, não apenas aqueles da mandíbula, chegam a níveis cervicais inferiores. Os neurônios para dor no núcleo espinhal do trigêmeo, assim como seu homólogo na medula espinal, foram classificados como neurônios de alto limiar, neurônios de baixo limiar e neurônios dinâmicos de amplo aspecto. Neurônios termoespecíficos foram localizados na margem do núcleo. Os axónios de neurônios situados no núcleo espinhal do nervo trigêmeo cruzam a linha mediana para formar o trato trigeminotalâmico anterior que se projetam para os neurônios situados no núcleo ventral póstero medial do tálamo (AFIFI \& BERGMAB, 2005).

A partir deste, as sensibilidades faciais são transmitidas à área da face no córtex somatossensitivo primário. No interior do trato trigeminotalámico, as fibras do ramo oftálmico (V1) do nervo trigêmeo estão localizadas mais lateralmente, enquanto as fibras do ramo mandibular (V3) são mais mediais. Além dos principais influxos oriundos de exterorreceptores da face, verificou-se que o núcleo espinhal do trigêmeo recebe um influxo do locus cerúleos na ponte e também envia fibras para ele. O influxo do locus cerúleos é inibitório. Devemos saber que o trato espinal do nervo trigêmeo possui, além de fibras condutoras de sensibilidade exteroceptivas da face, fibras somáticas gerais pertencentes aos nervos facial (VII nervo craniano), glossofaríngeo (IX nervo craniano), e vago (X nervo craniano) (AFIFI; BERGMAN, 2005). 


\subsection{TRATOS ESPINOTALÂMICOS E ESPINOCEREBELARES}

Os tratos espinotalâmicos estendem-se pelo bulbo bem próximo ao núcleo e trato espinhal do nervo trigêmeo (Fig. 6). Consequentemente, lesões nessa região do bulbo produzem perda de sensibilidade térmica e dolorosa na metade da face ipsilateral a lesão. Embora os tratos espinotalâmicos lateral e anterior mantenham suas posições medulares no bulbo inferior, a posição do trato espinotalâmicos anterior na região bulbar superior ainda não foi identificada de modo conclusivo em humanos, e suas fibras provavelmente se estendem juntamente com 0 trato espinotalâmico lateral. Como na medula espinhal, diversos indícios apontam para uma segregação de fibras para dor e para temperatura dentro do trato espinotalâmico lateral no bulbo.

Dessa forma, uma lesão superficial no bulbo que comprometa apenas a porção posterior do trato espinotalâmico lateral poderá resultar em perda somente de sensibilidade térmica.

As posições dos tratos espinocerebelares anterior e posterior na medula espinhal permanecem inalteradas na medula oblonga.

Outros tratos ascendentes e descendentes encontrados na medula espinal estendem-se pelo bulbo até níveis superiores ou inferiores (AFIFI; BERGMAN, 2005).

\subsection{NÍVEL DA DECUSSAÇÃO DOS LEMNISCOS MEDIAIS}

A característica diferencial no nível da decussação dos lemniscos mediais (sensitiva) é o cruzamento dos neurônios de segunda ordem do sistema da coluna posterior. Os axônios dos neurônios retransmissores dos núcleos da coluna posterior formam as fibras arqueadas internas e cruzam para o lado oposto (decussação sensitiva) acima das pirâmides e se juntam para formar o lemnisco medial do lado contralateral (Fig. 6). As informações das extermidades inferiores (axônios das células do núcleo grácil) são transportadas na parte anterior do lemnisco medial e as informações das extermidades superiores (axônios do núcleo cuneiforme) são transportadas na parte posterior do lemnisco medial. O lemnisco medial projeta-se para os neurônios do núcleo ventral posterior lateral do tálamo. Esse núcleo, por sua vez projeta-se para o córtex somatossensitivo primário. Lesões 
do lemnisco medial no bulbo resultam em perda de cinestesia e tato discriminativo contralateralmente à lesão (HAINES et al., 2006).

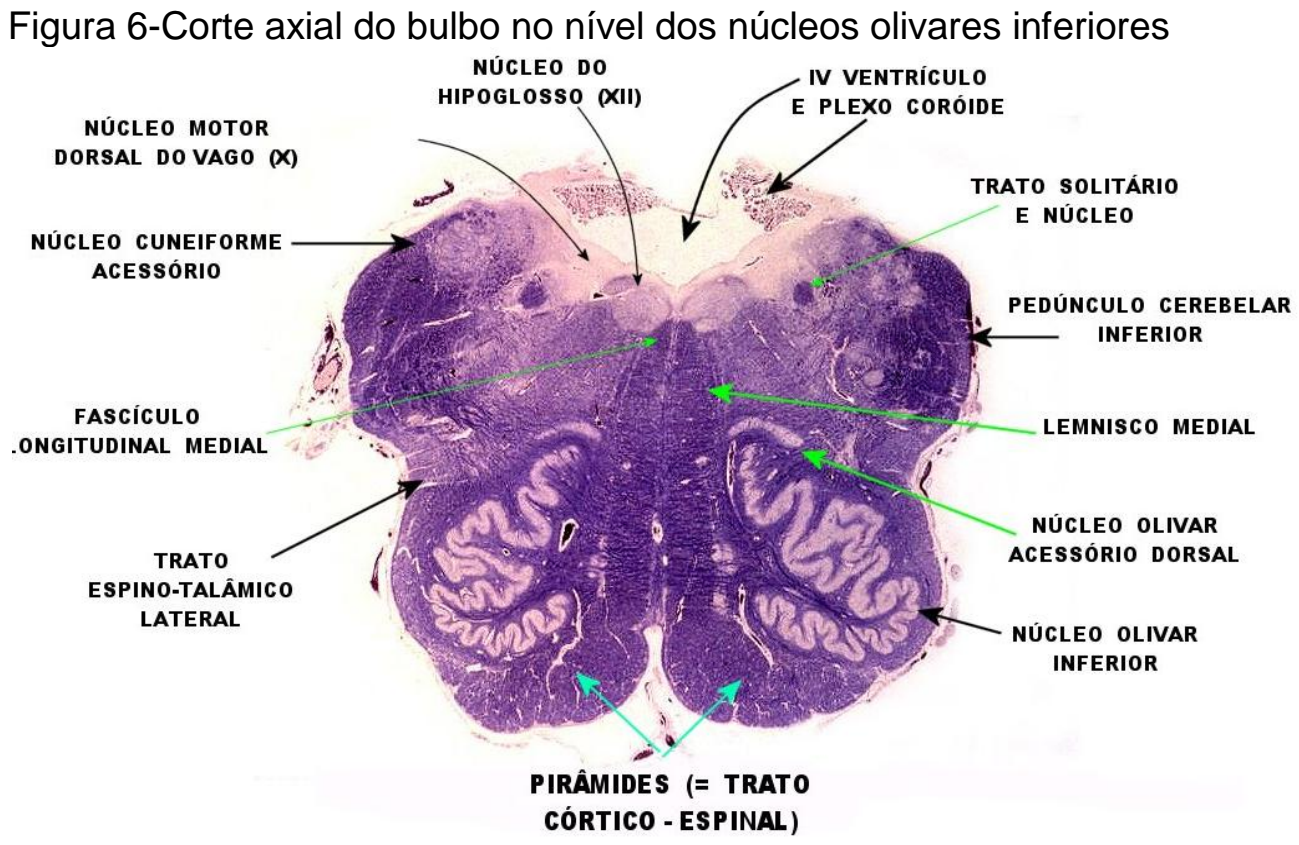

Fonte: Site Didático de Anatomia Pat., Neuropatologia e Neuroimagem (2015)

\subsection{FASCÍCULO LONGITUDINAL MEDIAL}

O fascículo longitudinal medial, situado póstero-lateralmente à decussação das pirâmides, é deslocado posteriormente pela decussação sensitiva fazendo com que se estenda posteriormente ao lemnisco medial.

Ele mantém essa posição por toda extensão do bulbo. As fibras descendentes desse feixe são oriundas de vários núcleos do tronco encefálico. As fibras vestibulares originam-se dos núcleos vestibulares medial e inferior. A formação reticular da ponte contribui com o maior número de fibras descendentes. Pequenos grupos de fibras se originam do núcleo dorsal do nervo oculomotor (intersticial de Cajal) na região superior do mesencéfalo (AFIFI; BERGMAN, 2005).

\subsection{NÚCLEO CUNEIFORME ACESSÓRIO}

Um grupo de grandes neurônios situados póstero lateralmente ao núcleo cuneiforme é conhecido como núcleo cuneiforme acessório (Fig. 6). Embora esse 
núcleo compartilhe seu nome com o núcleo cuneiforme, não pertence funcionalmente ao sistema da coluna posterior; ele é parte do sistema espinocerebelar posterior. As fibras do sistema espinocerebelar posterior que entram na medula espinhal acima do nível de C8 (limite superior do núcleo torácico posterior) sobem com as fibras da coluna posterior e terminam no núcleo cuneiforme acessório. Os neurônios da segunda ordem oriundos desse núcleo estendem-se póstero-lateralmente como fibras arqueadas externas posteriores e chegam ao cerebelo (fibras cuneocerebelares) pelo pedúnculo cerebelar inferior. Da mesma forma que o sistema espinocerebelar, o trato cuneocerebelar está relacionado à propriocepção inconsciente. Os neurônios do núcleo cuneiforme acessório recebem fibras dos nervos glossofaríngeo e vago, assim como de áreas vasopressoras e cardioaceleradoras do hipotálamo posterior. A estimulação do núcleo cuneiforme acessório produz bradicardia e hipotensão e essa resposta ocorre devido a um estímulo vagal. Cogitou-se que a hipertensão dispare o núcleo cuneiforme acessório, por meios de reflexos cardiovasculares, para produzir bradicardia e hipotensão. (AFIFI; BERGMAN, 2005).

\subsection{NÚCLEOS ARQUEADOS DO BULBO}

O grupo de neurônios situados na face anterior da pirâmide é conhecido como núcleo arqueado. Os núcleos arqueados aumentam significativamente de tamanho em níveis superiores do bulbo e tornam-se contínuos com os núcleos da ponte.

As conexões aferentes e eferentes dos núcleos arqueados são idênticas as dos núcleos da ponte. Seu principal influxo provém do córtex cerebral contralateral; o principal efluxo estende-se às metades ipsi e contralateral do cerebelo através do pedúnculo cerebelar inferior. As fibras arqueado-cerebelares chegam ao pedúnculo cerebelar inferior por duas vias. Uma delas percorre a superfície da medula oblonga (fibras arqueadas externas anteriores); a outra via se estende pela linha mediana da medula oblonga curvando-se lateralmente no assoalho do quarto ventrículo para formar as estrias medulares do quarto ventrículo (AFIFI; BERGMAN, 2005). 


\subsection{1 ÁREA POSTREMA}

A área postrema descrita por Retzius em (1896), é uma estrutura bilateral, localizada na porção inferior do assoalho do quarto ventrículo, imediatamente acima do óbex, e separada do trígono do vago pelo funiculus separans. Recebeu esta nomenclatura por estar localizada na extremidade caudal do encéfalo. É uma das regiões mais vascularizadas do encéfalo dos mamíferos, com o acesso exclusivo à circulação devido à presença de capilares fenestrados. A área postrema e formada por células similares a astroblastos, arteríolas, sinusoides e alguns neurônios apolares e unipolares. Ela é uma dentre várias áreas do sistema nervoso central que não tem uma barreira hematoencefálica. Essas áreas são denominadas coletivamente de órgão circunventriculares incluem além da área postrema, o órgão subfornicial, o órgão subcomissural a glândula pineal, a eminência mediana, a neuro hipófise e o órgão vascular da lámina terminal.

Todas essas áreas com exceção da área postrema, são estruturas medianas ímpares relacionadas ao diencéfalo. Em animais experimentais, a estimulação da área postrema induz ao vômito, sugerindo ser um centro emético quimissensitivo (AFIFI; BERGMAN, 2005).

Semelhante a outras áreas periventriculares do assoalho da fossa romboide a área postrema expressa em suas células a proteína de membrana AQP4 (aquaporina-4) alvo principal das lesões da neuromielite óptica. Desta forma, manifestações desta patologia pode ser vômitos, náuseas e soluços intratáveis por lesões na área postrema (POPESCU et al., 2011).

\subsection{BULBO NO NÍVEL DAS OLIVAS}

$\mathrm{Na}$ medula oblonga, a característica diferencial no nível das olivas é a presença do complexo de núcleos olivar inferior, que formam lâminas contorcidas de substância cinzenta, localizadas posteriormente às pirâmides (Fig.7). Esses complexos nucleares salientam-se na superfície ântero-lateral da medula oblonga como estruturas em formato de azeitonas. O complexo olivar inferior consiste em três grupos nucleares: núcleo olivar principal (o maior núcleo), núcleo olivar acessório posterior e o núcleo olivar acessório medial. Em humanos, estima-se que 
o complexo olivar inferior contenha quinhentos mil neurônios. Esse complexo é envolvido por um aglomerado de fibras conhecido como amículo olivar. O complexo olivar inferior recebe fibras das seguintes áreas: Córtex cerebral, através do trato corticoespinhal, para os dois núcleos olivares principais; Núcleos da base, através do trato tegmental central para os dois núcleos olivares principais; Mesencéfalo (substância cinzenta periaquedutal) e núcleo rubro, através do trato tegmental central, para o núcleo olivar principal ipsilateral. No Bulbo, os núcleos da coluna posterior projetam-se para o núcleo olivar acessório contralateral. Os núcleos vestibulares inferior e medial projetam-se para os dois complexos olivares inferiores. Os dois complexos olivares inferiores são interconectados; Cerebelo através do pedúnculo cerebelar superior, os núcleos denteado e interpósito projetam-se para os núcleos olivares principal e acessório; Medula espinal, através do trato espinolivar, para os núcleos olivares acessórios de ambos os lados.

O principal efluxo do complexo olivar inferior dirige-se ao cerebelo (trato olivocerebelar). As fibras olivo-cerebelares provêm dos dois complexos olivares inferiores contudo originam-se principalmente do complexo contralateral. Elas saem pelo hilo do núcleo olivar inferior cruzam o lemnisco medial e se estendem através do complexo olivar inferior oposto para entrarem no cerebelo pelo pedúnculo cerebelar inferior. As fibras olivocerebelares constituem o principal componente do pedúnculo cerebelar inferior e estão localizadas em sua porção ântero-medial. As fibras olivocerebelares que se originam dos núcleos olivares acessórios e da parte medial do núcleo olivar principal projetam-se para o verme do cerebelo enquanto as fibras que se originam do restante do núcleo olivar principal projetam-se para os hemisférios do cerebelo. Os núcleos cerebelares também recebem fibras do trato olivocerebelar (AFIFI; BERGMAN, 2005).

Apesar de décadas de pesquisa e conhecimento detalhado da microanatomia e circuitos do sistema olivocerebellar, sua função continuam a ser um tema de debate contínuo (BLOEDEL; BRACHA 1998).

O complexo olivar inferior está intimamente associado com o cerebelo, o que significa que ele está envolvido no controle e coordenação dos movimentos, processamento sensorial e tarefas cognitivas provavelmente codificando o momento da entrada sensorial independentemente de atenção ou consciência. Lesões do núcleo olivar inferior têm sido associados com uma diminuição da capacidade de aprimorar tarefas motoras altamente especializadas, tais como melhorar a precisão 
de atingir um alvo com uma bola. Há alguma evidência de que ele é estimulado pela Ghrelin (AFIFI; BERGMAN, 2005).

Figura 7-Corte axial do bulbo no nível dos pedúnculos cerebelares inferiores

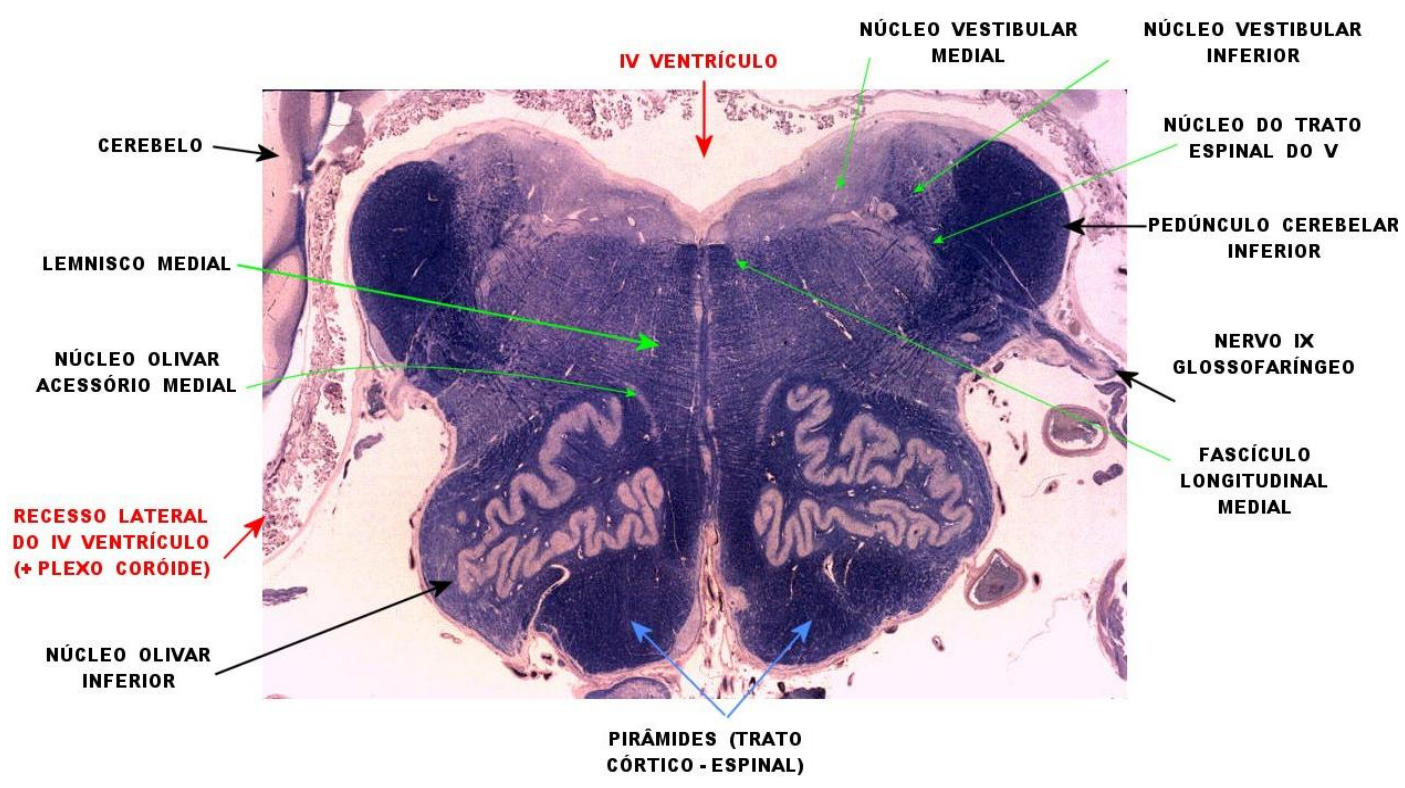

Fonte: Site Didático de Anatomia Pat., Neuropatologia e Neuroimagem (2015)

\subsection{FORMAÇÃO RETICULAR BULBAR}

A formação reticular do bulbo é caracterizada por grande quantidade de neurônios de vários tamanhos e formas entremeadas por uma complexa rede de fibras (Fig.8). Ela se estende pela área situada entre as pirâmides (anteriormente) e o assoalho do quarto ventrículo (posteriormente).

A formação reticular é uma região filogeneticamente antiga e, em seres inferiores, constitui a principal parte do sistema nervoso central. Inferiormente a formação reticular aparece no nível da decussação das pirâmides. Superiormente, ela é contínua com a formação reticular da ponte. Fisiologicamente, a formação reticular é um sistema polissináptico rico em fibras colaterais para distribuição de impulsos. Na formação reticular, núcleos distintos são praticamente impossíveis de identificar, embora as unidades funcionais possam ser isoladas do ponto de vista fisiológico. A grande maioria dos neurônios dessa rede é composta de interneurônios que têm múltiplas progessões eferentes resultando em inúmeros contatos sinápticos. 
Figura 8-Corte axial no nível da transição bulbo pontina

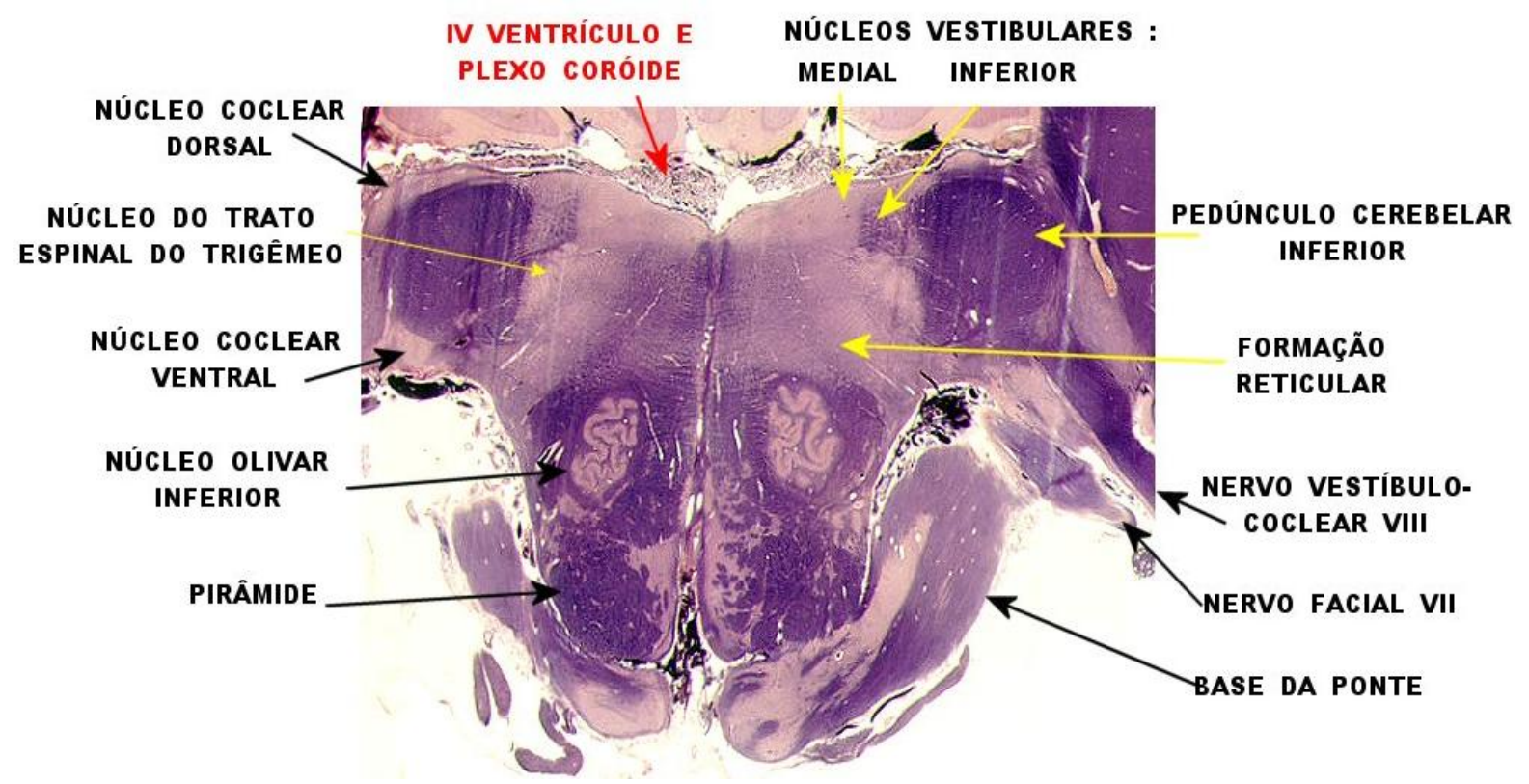

Fonte: Site Didático de Anatomia Pat., Neuropatologia e Neuroimagem (2015)

Todo neurônio da formação reticular pode processar informações ipsilaterais e contralaterais. Além disso, as projeções de um único neurônio podem ser tanto ascendentes quanto descendentes. Todos os sistemas da formação reticular são influenciados pelas projeções de outras áreas do cérebro e podem, por sua vez, influenciar a função dessas áreas, e umas às outras. Assim, a formação reticular é verdadeiramente o integrador do sistema nervoso central (SNC).

A formação reticular pode ser subdividida em três componentes funcionais 1) zona lateral, que processa a informação aferente sensorial; 2) a zona medial, que processa a informação eferente motora; e 3) a soma dos sistemas neurotrasmissores que se projetam para áreas amplas do SNC. Juntas as projeções da formação reticular que ascendem para o tálamo e córtex e atuam na modulação da consciência são chamadas de sistema ativador reticular ascendente (SARA).

A zona lateral da formação reticular recebe aferências da medula espinal via trato espinorreticular. Seus neurônios se projetam para a zona medial, a fim de modular a função motora, para os núcleos de sistemas de neurotransmissores que influenciam o nível de consciência, bem como para o tálamo. Algumas projeções ascendentes também podem influenciar o sistema nervoso autônomo por meio de projeções para o hipotálamo. 
A zona medial da formação reticular tem projeções eferentes que modulam os estímulos motores. Tem conexões recíprocas com todos os sitemas envolvidos no controle do movimento: o córtex e o tálamo; os núcleos da base, o cerebelo; e a medula espinal. Projeta-se aos neurônios motores inferiores pelo trato reticuloespinhal. Uma das principais funções dessa parte da formação reticular é manter o tônus muscular durante o movimento, o que é conseguido por um equilíbrio entre as projeções excitatórias e inibitórias para o neurônio motor inferior. Esse equilíbrio decorre da integração da toda a informação motora descendente com a informação sensorial ascendente.

Soma dos sistemas neurotramissores são uma série de redes paralelas de sistemas de neurotrasmissores que se projeta para diversas áreas do SNC e influencia o nível de consciência e sono/vigília, bem como atua no processamento da dor, da motivação, da emoção e recompensa e do vício. Os sistemas de neurotramissores mais importantes incluem aqueles envolvendo a dopamina (DA), a noradrenalina(NA) e a serotonina(5-HT) (AFIFI; BERGMAN, 2005).

\subsection{FUNÇÕES DA FORMAÇÃO RETICULAR DO BULBO}

A formação reticular é composta por mais de 100 pequenas redes neurais, com fun ções variadas incluindo o seguinte:

a) Controle motor somático- Alguns neurônios motores enviam seus axônios para núcleos da formação reticular, dando origem aos tratos reticuloespinhal da medula espinhal. A função destes tratos e manter o tônus, equilíbrio e postura especialmente durante os movimentos do corpo. A formação reticular também retransmite sinais das orelhas e olhos para o cerebelo, e assim o cerebelo pode integrar estímulos visuais, auditivos e vestibulares com a coordenação motora. Outros núcleos motores incluem centros do olhar, que permitem os olhos acompanhar e fixar objetos e geradores de padrão central, que produzem sinais rítmicos para os músculos da respiração e da deglutição.

b) Controle cardiovascular - A formação reticular inclui centros vasomotores e cardíacos da medula oblonga.

c) Modulação da dor - A formação reticular é um meio pelo qual os sinais de dor da parte inferior do corpo atinge o córtex cerebral. É também a origem das vias 
analgésicas descendentes. As fibras nervosas destas vias agem na medula espinal bloqueando a transmissão de alguns sinais de dor ao cérebro.

d) Sono e consciência - A formação reticular tem projeções para o tálamo e córtex cerebral, que the permitem exercer algum controle sobre os sinais sensoriais que chegam ao cérebro e tomamos consciência. Ela também desempenha um papel central em estados de sono/vigília. Lesão da formação reticular pode resultar em coma irreversível.

d) Habituação - Este é um processo no qual o cérebro aprende a ignorar estímulos repetitivos ou sem sentido, permanecendo sensível aos outros. Um bom exemplo disso é quando uma pessoa consegue dormir ouvindo o barulho de um alto tráfego em uma cidade grande, mas é despertado prontamente devido ao som de um alarme ou bebê chorando. Núcleos da formação reticular que modulam a atividade do córtex cerebral são chamados de sistema ativador reticular ou sistema modulador de controle extratalámico (KOTCHABHAKDI, 2011).

\subsection{PEDÚNCULO CEREBELAR INFERIOR}

O tronco encefálico e o cerebelo são conectados por três pedúnculos: 0 pedúnculo cerebelar inferior (corpo restiforme e corpo justarestiforme) entre a medula oblonga e o cerebelo; O pedúnculo cerebelar médio (braço da ponte), entre a ponte e o cerebelo; e o pedúnculo cerebelar superior (braço conjuntivo) entre o cerebelo e o mesencéfalo (Fig.7).

O pedúnculo cerebelar inferior localiza-se na margem póstero-lateral da medula oblonga. Situa-se superiormente aos tubérculos grácil e cuneiforme e forma um feixe distinto aproximadamente no nível médio olivar. As fibras contidas no pedúnculo cerebelar inferior (corpo restiforme) incluem os seguintes tratos aferentes e eferentes(com origem ou destino bulbar e espinhal):

a) Trato olivocerebelar ( o maior componente dete pedúnculo).Conecta a oliva ao cerebelo.

b) Trato espinocerebelar posterior. Origina-se no núcleo torácico posterior (de Clark) e chega ao cerebelo.

c) Trato reticulocerebelar. Conecta a formação reticular ao cerebelo.

d) Trato cuneo cerebelar. Origina-se no núcleo cuneiforme acessório e se estende ao cerebelo. É homólogo ao trato espinocerebelar posterior. 
e) Trato arqueadocerebelar. Conecta o núcleo arqueado ao cerebelo.

f) Trato cerebeloolivar.Conecta o cerebelo ao complexo olivar inferior.

g) Trato trigeminocerebelar. Estende-se dos núcleo espinal (bulbo) e principal (ponte) do nervo trigêmeo ao cerebelo.

h) Fibras dos núcleos periipoglossais (relacionadas aos movimentos oculares) ao cerebelo.

Uma pequena parte medial do pedúnculo cerebelar inferior é conhecida como corpo justarestiforme e contém os seguintes tratos:

a) Trato cerebelorreticular. Conecta o cerebelo à formação reticular.

b) Trato cerebelovestibular. Conecta o cerebelo aos núcleos vestibulares.

c) Trato vestibulocerebelar. Fibras vestibulares secundárias dos núcleos vestibulares ao cerebelo.

d) Fibras nervosas vestibulares diretas ao cerebelo (sem sinapses nos núcleos vestibulares).

e) Trato cerebeloespinhal.Estende-se do cerebelo aos neurônios motores da parte cervical da medula espinal.

As lesões do pedúnculo cerebelar podem causar sintomas clínicos variáveis, que vão desde a vertigem ou vômitos como o único quadro clínico de paralisia facial, ataxia, nistagmo, diplopia, disfagia, disartria, surdez, fraqueza motora contralateral, perda sensorial trigeminal, dismetria do membro, perda de sensação de dor e temperatura, a síndrome de Horner, e" síndrome do encarceramento". (MORITANI et al., 2003).

\subsection{NÚCLEOS DE NERVOS CRANIANOS DO BULBO}

Os nervos cranianos a seguir possuem seus núcleos na medula oblonga: 1) Hipoglosso (XII nervo craniano); 2) Acessório (XI nervo craniano); 3) Vago (X nervo craniano); 4) Glossofaríngeo (IX nervo craniano); e o vestibulococlear (VIII nervo craniano)

a) Nervo hipoglosso (XII nervo craniano)

O nervo hipoglosso contém, principalmente, fibras nervosas motoras somáticas que inervam os músculos intrínsecos e extrínsecos da língua. Possui 
também fibras proprioceptivas originadas dos fusos neuromusculares situados nos músculos da língua. A terminação central das fibras aferentes proprioceptivas do nervo hipoglosso não é bem conhecida.Verificou-se que os núcleos do trato solitário e do nervo hipoglosso recebem estas aferências.

O núcleo do nervo hipoglosso estende-se por toda a medula oblonga, exceto em seus níveis mais superiores e inferiores. Este núcleo é dividido em grupos celulares que correspondem aos músculos da língua inervados por eles. A estrutura onde está localizada este núcleo corresponde ao trígono do nervo hipoglosso, no assoalho do quarto ventrículo. O núcleo recebe fibras corticorreticulonucleares cruzadas e diretas. As fibras radiculares do nervo estendem-se pela medula oblonga lateralmente ao lemnisco medial e emergem na face anterior da medula oblonga entre a pirâmide e a oliva.

Alguns agrupamentos nucleares bem próximos ao núcleo do nervo hipoglosso são provavelmente neurônios reticulares. Eles não contribuem com fibras para o nervo hipoglosso e são conhecidos como núcleos periipoglossais ou satélites (núcleo intercalado, núcleo prepósito, e núcleo subipoglossal). Estes núcleos recebem influxo de 1) córtex cerebral, 2) núcleos vestibulares, 3) núcleos acessórios do nervo oculomotor e 4) formação reticular pontina paramediana. O efluxo desses núcleos termina nos 1) núcleos dos nervos cranianos envolvidos nos movimentos oculares (oculomotor,troclear e abducente) 2) cerebelo e 3) tálamo.

Os núcleos periipoglossais e suas conexões são parte de uma circuitaria complexa relacionada aos movimentos oculares. Lesões no núcleo ou nervo hipoglosso resultam em paralisia da musculatura da língua, do tipo neurônio motor inferior, ipsilateral à lesão que se manifesta pelos seguintes sintomas: Diminuição ou perda de movimento da metade ipsilateral da língua; Atrofia dos múculos da metade ipsilateral da língua; Fasciculação dos músculos da metade ipsilateral da língua; Desvio da língua quando protraída para o lado atrofiado (por ação do músculo genioglosso normal).

b) Nervo acessório (XI nervo craniano)

O nervo acessório possui duas raízes: espinhal e craniana. A raiz espinhal origina-se do núcleo do nervo acessório, uma coleção de neurônios motores no corno anterior dos cinco ou seis primeiros segmentos medulares cervicas e da parte 
inferior do bulbo. A partir das células de origem, as radículas se estendem pósterolateralmente e emergem na região lateral da medula espinal entre as raízes anterior e posterior. A raiz espinhal do nervo acessório adentra a cavidade do crânio através do forame magno e sai da mesma cavidade pelo forame jugular, além disso contém fibras motoras somáticas que inervam os músculos esternocleidomastóideos e trapézio (parte ascendente).

A raíz craniana origina-se na medula oblonga do polo inferior do núcleo ambíguo. Essa raíz emerge na face lateral da medula oblonga, une-se às radículas no nervo vago (formando seu ramo laríngeo recorrente) e inerva os músculos intrínsecos da laringe. Consequentemente, a raíz craniana do nervo acessório é em princípio, parte do nervo vago.

O nervo laríngeo recorrente também conhecido como nervo de Galeno (130 a 200 AC) o qual descubriu que este nervo controlava a voz (AFIFI; BERGMAN, 2005).

c) Nervo vago ( $\mathrm{X}$ nervo Craniano)

O nervo vago é um nervo misto que contém fibras aferentes e eferentes, está associada a quatro núcleos da medula oblonga. Os componentes eferentes do nervo estão relacionados a dois núcleos bulbares.

d) Núcleo posterior do nervo vago

O núcleo posterior do nervo vago é uma coluna de células situada póstero lateral ou lateralmente ao núcleo do nervo hipoglosso, estendendo-se superior e inferiormente alguns milimetros além deste último. Os axónios dos neurônios situados nessa coluna estendem-se ântero-lateralmente pela medula oblonga e emergem na face lateral desta entre a oliva e o pedúnculo cerebelar inferior. Os axónios originados desse núcleo são fibras parassimpáticas pré-gangilonares que conduzem impulsos eferentes viscerais gerais para as víceras torácicas e abdominais. As fibras pós-ganglionares originam-se dos gánglios terminais situados no interior ou na superficie da víscera torácica ou abdominal inervada.O núcleo posterior do nervo vago recebe fibras dos núcleos vestibulares; consequentemente, 
a estimulação vestibular excessiva resulta em náusea, vômito e alteração da frequência cardica.

e) Núcleo ambíguo

Núcleo ambíguo conhecido também como núcleo motor ventral do vago. É uma coluna de células situada a meio caminho entre a oliva e o núcleo espinhal do trigêmio. Seus axónios estendem-se póstero-medialmente e, em seguida, curvam-se ântero-lateralmente para emergir na face lateral da medula oblonga entre a oliva e o pedúnculo cerebelar inferior. Esses axónios conduzem impulsos eferentes viscerais especiais aos músculoas braquiméricos da faringe e da laringe (constrictores da faringe, cricotireóideo , músculos intrínsecos da laringe, levantador do véu palatino, palatoglosso, palatofaríngeo e músculo da úvula). Além do nervo vago, o núcleo ambíguo contribui com fibras eferentes para os nervos glossofaríngeo e acessório.

Os componentes aferentes do nervo vago estão relacionados a dois núcleos bulbares:

- Núcleo espinhal do nervo trigêmio: recebe fibras afrentes somáticas gerais do pavilhao auricular, do meato acústico externo e da face externa da membrana timpânica.

- Núcleo do trato solitário: recebe dois tipos de fibras aferentes viscerais:

- Fibras aferentes viscerais gerais: conduzem sensibillidade viscerais gerais da faringe, laringe, traquéia e esôfago, assimcomo das vísceras torácicas e abdominais.

- Fibras aferentes viscerais especiais: conduzem sensibilidade gustatória da região da epiglote (AFIFI; BERGMAN, 2005).

\subsection{NERVO GLOSSOFARÍNGEO (IX NERVO CRANIANO)}

O nervo glossofaríngeo é também um nervo misto,esta associado a quatro núcleos no bulbo. Seus componentes eferentes estão relacionados em dois núcleos: - Núcleo ambíguo: as fibras axonais que estão no nervo glossofáringeo tem sua origem nos nerônios situados na parte posterior do núcleo ambíguo e inervam o músculo estilofaríngeo o qual eleva a faringe durante a fala e a deglutição.Essa parte do nervo glossofaríngeo é pequena. 
- Núcleo salivatório inferior: o núcleo salivatório inferior é um agrupamento de neurônios situados na região posterior do bulbo, de difícil distinção em relação aos neurônios reticulares. Os axônios dos neurônios situados nesse núcleo saem do bulbo por sua face lateral. Esses axônios são fibras eferentes viscerais gerais préganglionares que conduzem impulsos secretores motores em direção à glándula parótida.

Eles se estendem pelo nervo petroso menor até o gânglio ótico,a partir do qual as fibras pós ganglionares inervam a glândula parótida. Como exemplo podemos ter "a boca seca" em resposta ao medo e à ansiedade, e a salivação em resposta ao "cheiro da comida", estas reações refletem influxos ao núcleo salivatório superior provenientes do hipotálamo e do sistema olfatório, respectivamente.

Os componentes aferentes do nervo glossofaríngeo estão relacionados aos mesmos dois núcleos associados ao vago:

a) Núcleo espinhal do nervo trigêmeo. Esse núcleo recebe fibras aferentes somáticas gerais da região retroauricular. Os corpos neuronais de origem dessas fibras estão localizados no gânglio superior dentro do forame jugular.

b) Núcleo do trato solitário. Esse núcleo recebe dois tipos de fibras aferentes viscerais:

- Fibras aferentes viscerais gerais: conduzem sensibilidade tátil,dolorosa e térmica das túnicas das mucosas do terço posterior da língua,tonsilas e tuba auditiva

- Fibras aferentes viscerais especiais: conduzem sensibilidade gustatória dos terço posterior da língua.

Os corpos neuronais que originam as fibras aferentes viscerais estão localizados no gânglio inferior (petroso). No interior do bulbo,formam o trato solitário e projetam-se para o núcleo do trato solitário de modo semelhante ao descrito para o nerovo vago.

O nervo glossofaríngeo também contém uma ramificação com fibras aferentes especiais, o ramo para o seio carotídeo. Esse ramo inerva o glomo e seio carotídeos que são os centros quimio e baroreceptores, respectivamente. A elevação da pressão arterial carótica estimula o ramo para o seio carótico que, ao chegar a medula oblonga, envia colaterais ao núcleo posterior do vago.

Em seguida, os componentes eferentes viscerais gerais do nervo vago chegam às células pós-ganglionares situadas na parede cardíaca, que dimunuem a frequência cardíaca e reduzem a pressão arterial. O reflexo glossofaríngeo-vagal é 
particularmente sensível em pessoas idosas. Portanto, deve-se tomar cuidado extremo ao manipular a região carotídea no pescoço em uma pessoa idosa.

As Lesões unilaterais do nervo glossofaríngeo determinam o aparecimento dos seguintes sinais:

a) Perda do reflexo faríngeo (ânsia de vômito) ipsilateral à lesão nervosa. Esse reflexo é produzido pela estimulação da parede posterior da faringe,da região tonsilar ou da base da língua.Normalmente, a retusão da língua está associada à elevação e constricção da musculatura da faringe.

b) Perda do reflexo do seio carotídeo ipsilateral à lesão nervosa.

c) Perda ipsilateral de sensibilidade gustatória no terço posterior da língua.

d) Desvio da úvula para o lado íntegro.

O núcleo do trato solitário é dividido em duas zonas. A zona infero-medial que está relacionada à sensibilidade visceral geral $e$, principalmente, à função cardiorespiratória. A zona súpero-lateral está realcionada à função visceral especial (gustação). Inferiormente, as duas porções mediais dos núcleos dos tratos solitários fundem-se para formar o núcleo comissural.

A zona gustatória recebe sensibilidade gustatória por três nervos cranianos: o nervo facial que conduz sensibilidade gustatória dos dois terços anteriores da língua,o nervo glossofaríngeo do terço posterior da língua e o nervo vago da epiglote. O efluxo da zona gustatória estende-se à região posterior do tálamo (núcleo ventral póstero-medial),que por sua vez projeta-se para o córtex gustatório primário.

\subsection{NERVO VESTÍBULO-COCLEAR(VIII NERVO CRANIANO)}

Trata-se de um nervo exclusivamente sensitivo que ocupa, juntamente com os nervos Facial e Intermédio, o meato acústico interno. Compõe-se de uma parte vestibular e uma parte coclear, que, apesar de unidas em um tronco comum, possuem origens, funções e conexões centrais diferentes.

A parte vestibular é formada por fibras sensitivas que se originam dos neurônios sensitivos do gânglio vestibular, estando relacionada com a manutenção do Equilíbrio do corpo. Já a parte coclear é constituída por fibras originadas nos neurônios sensitivos do gânglio espiral, estando relacionada com a audição. As fibras desse nervo classificam-se como Aferentes Somáticas Especiais. 


\subsection{SUPRIMENTO SANGUÍNEO DO BULBO}

A medula oblonga recebe suprimento sanguíneo das seguintes artérias: 1) vertebral; 2) espinhal anterior; 3) espinhal posterior ; 4)artéria cerebelar inferior posterior.

A medula oblonga (bulbo) é dividida em quatro áreas vasculares:paramediana, olivar, lateral e posterior. A área paramediana recebe suprimento sanguíneo da artéria vertebral e ou artéria espinhal anterior. Essa região abrange a pirâmide, o lemnisco medial, o fascículo longitudinal medial e o núcleo e nervo hipoglosso. A área olivar recebe suprimento sanguíneo inconstante da artéria vertebral. Essa região inclui a maior parte do complexo olivar inferior. A área lateral recebe suprimento sanguíneo constante da artéria vertebral e suprimento variável da artéria cerebelar inferior posterior.

Esse território engloba o núcleo posterior do nervo vago,o núcleo e trato solitário, os núcleos vestibulares, o núcleo ambíguo, o núcleo e trato espinhal do nervo trigêmeo, o trato espinotalâmico lateral, o pedúnculo cerebelar inferior e a via olivocerebelar. A área posterior é suprida superiormente pela artéria cerebelar inferior posterior e inferiormente pela artéria espinhal posterior. Esse território inclui os núcleos vestibulares,os tratos e núcleos da coluna posterior e parte do pedúnculo cerebelar inferior (AFIFI; BERGMAN, 2005).

\subsection{CORRELATOS CLÍNICOS DO BULBO}

As lesões vasculares na medula oblonga são as mais condizentes com as correlações anatomoclínicas. No passado, essas síndromes eram disignadas pelas artérias responsáveis pela irrigação da região como por exemplo sindrome da artéria espinhal anterior, sindrome da antéria cerebelar posterior inferior,síndrome da artéria vertebral). No entanto, em razão das variaçãoes na origem do suprimento sanguíneo, atualmente essas síndromes são disignadas pela região afetada pela lesão (AFIFI; BERGMAN, 2005). Principais síndromes descritas pelos autores: 


\subsubsection{Síndrome bulbar medial (síndrome bulbar anterior de Dejerine)}

A síndrome bulbar medial é causada por oclusão da artéria espinhal anterior ou de ramos paramedianos da artéria vertebral. A área afetada geralmente incluie as seguintes estruturas: Lemnisco medial; Pirâmide; Radículas do nervo hipoglosso, ou de seu núcleo, no interior da medula oblonga. Os sinais neurológicos que resultam do comprometimento destas áreas são:

-Perda contralateral de cinestesia e tato discriminativo, resultante de comprometimento do lemnisco medial.

Figura 9- Imagem de RM em T2 axial do bulbo evidenciando Infarto medial direito

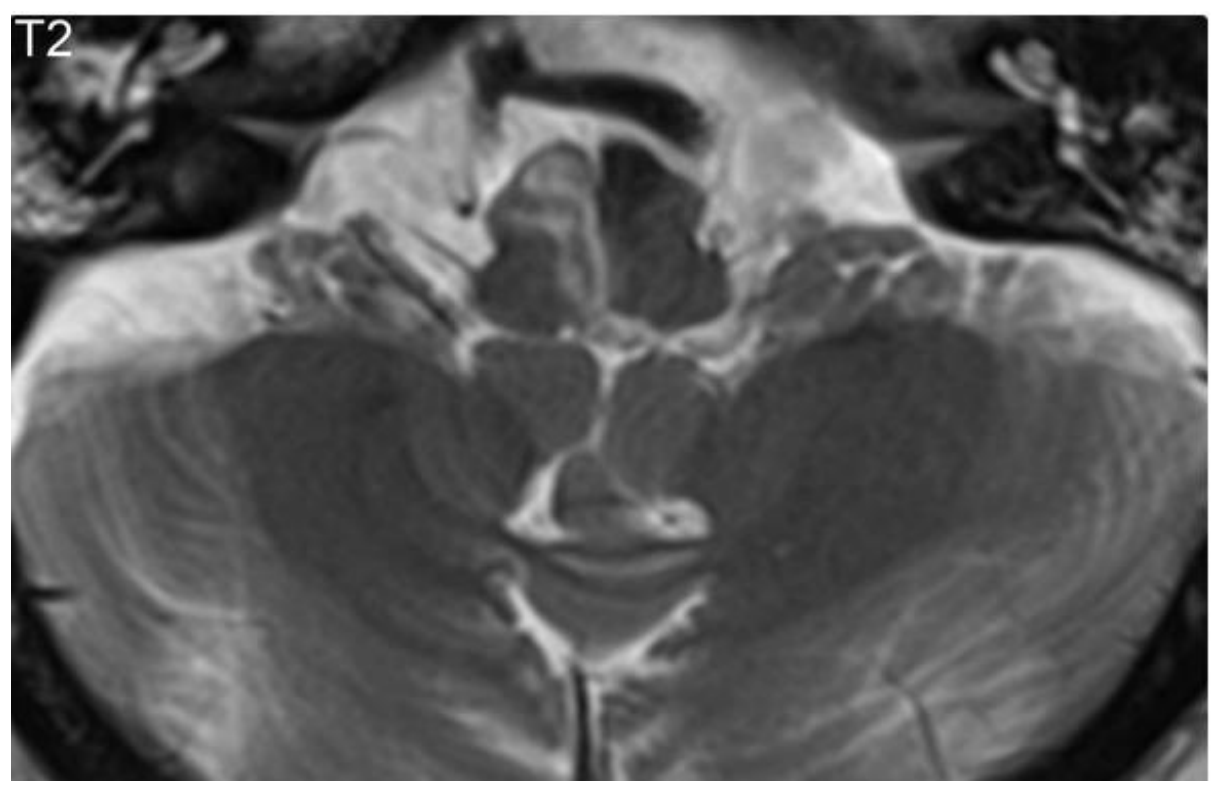

Fonte: Goel e Gaillard (2015-2016).

-Paralisia contralateral do tipo neurônio motor superior (fraqueza, reflexos hiperativos, sinal de Babinski, clônus e espasticidade) com preservação da face, causada por comprometimento da pirâmide.

-Paralisia do tipo neurônio motor inferior da metade ipsilateral da língua (fraqueza, atrofia e fibrilação) e desvio da língua protraida para o lado atrofiado, em decorrência do comprometimento do núcleo ou do nervo hipoglosso).

A síndrome bulbar medial pode ocorrer bilateralmente, resultando em fraqueza ou paralisia bilateral do tipo neurônio motor superior (com preservação da 
face), paralisia bilateral da língua do tipo neurônio motor inferior e perda bilateral da cinestesia e tato discriminativo.

A sindrome bulbar lateral é causada por oclusão da arteria vertebral ou, menos frequentemente, do ramo medial da artéria cerebelar inferior posterior, quando essa artéria irriga o bulbo. A área afetada inclui as seguintes estruturas: Núcleo espinhal do nervo trigêmio e seu trato; Trato espinotalámico adjacente; Núcleo ambíguo ou seu axónios; Base do pedúnculo cerebelar inferior; Núcleos vestibulares; Fibras simpáticas descendentes do hiptálamo; Fibras olivocerebelares.

Os sinais e sintomas neurológicos resultantes do comprometimento dessas áreas incluem: Perda da sensibilidade dolorosa e térmica da metade ipsilateral da face em consequência do comprometimento do trato e do núcleo espinhal do nervo trigêmeo; Perda da sensibilidade dolorosa e térmica da metade contralateral do corpo, devido ao comprometimento do trato espinotalámico.

Figura 10-Imagem de RM em T1 e T2 axial do bulbo evidenciando infarto lateral direito
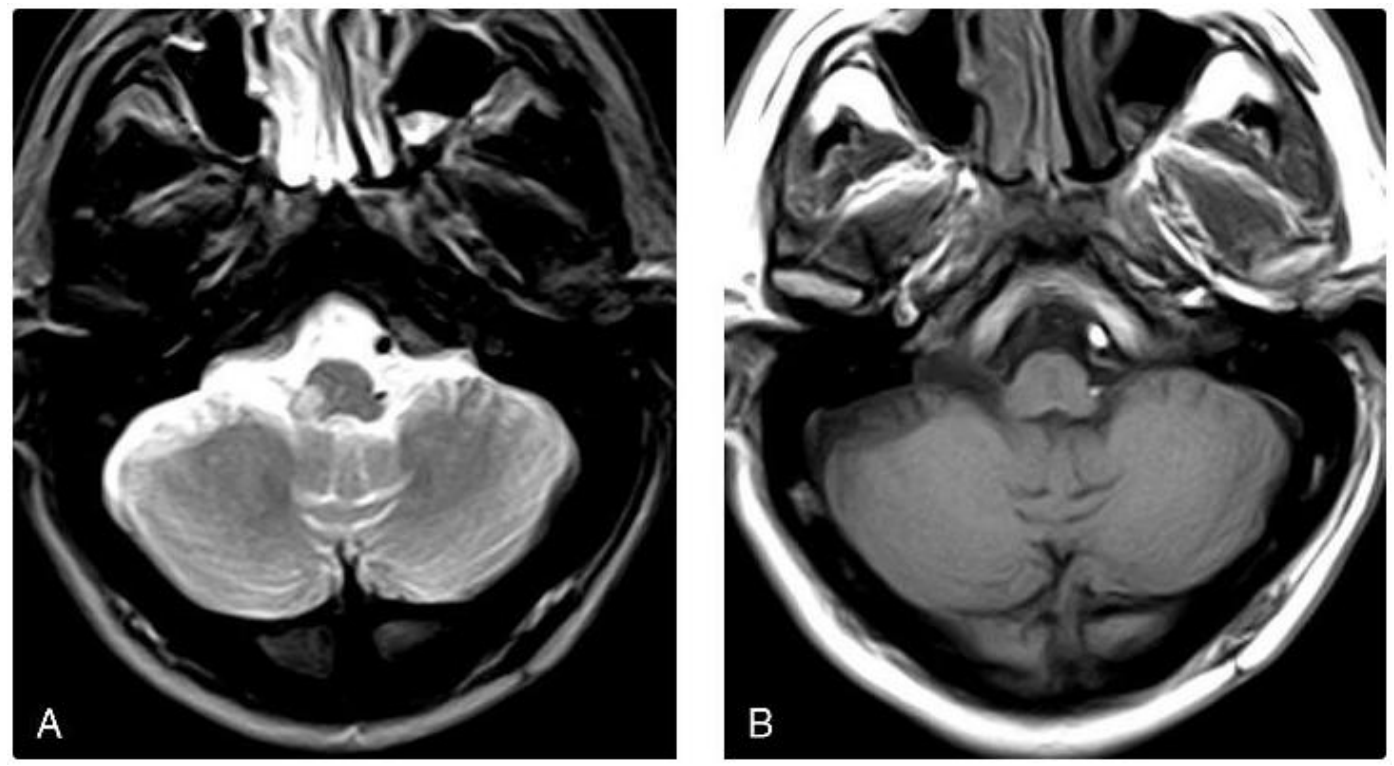

Fonte: Goel; Gaillard (2015-2016).

\subsubsection{Sindrome bulbar lateral}

A síndrome bulbar lateral é causada por oclusão da artéria vertebral ou, menos frequentemente, do ramo medial da artéria cerebelar inferior posterior, quando essa artéria irriga o bulbo.Também é conhecida como síndrome da artéria 
cerebelar inferior posterior ou síndrome de Wallemberg. A área afetada geralmente inclui as seguintes estruturas:

-Núcleo espinhal do nervo trigêmio

-Trato espinotalámico adjacente

-Núcleo ambíguo

-Base do pedúnculo cerebelar inferior

-Núcleos vestibulares

-Fibras simpáticas descendentes do hipotálamo

-Fibras olivocerebelares

Os sinais e sintomas neurológicos resultantes do compromentimento dessas áreas incluem:

-Perda de sensibilidade dolorosa e térmica da metade ipsilateral da face em consequência do comprometimento do trato e do núcleo espinhal do nervo trigêmio. -Perda da sensibilidade dolorosa e térmica da metade contralateral do corpo,devido ao comprometimento do trato espinotalámico.

-Perda do reflexo faríngeo,dificuldade para deglutir,roquidão e dificuldade de articulação da fala,causado por paralisia dos músculos inervados pelo núcleo ambíguo ipsilateral a lesão bulbar.

-Perda ipsilateral de coordenação resultante do comprometimento da base do pedúnculo cerebelar inferior.

-Síndrome de Horner causado por comprometimento das fibras simpáticas descendentes do hipotálamo.

\subsection{3 síndrome bulbar posterior}

A síndrome bulbar posterior é causada por oclusão do ramo medial da artéria cerebelar inferior posterior. As estruturas afetadas incluem os núcleos vestibulares e o pedúnculo cerebelar inferior. Estão presentes os seguintes sinais neurológicos:

- Ataxia ipsilateral dos membros ou marcha atáxica,resultante do comprometimento do pedúnculo cerebelar inferior.

-Vertigem, vômito e nistagmo evocado pelo olhar ipsilateral, resultante do comprometimento dos núcleos vestibulares. 


\subsubsection{Paralisia pseudobulbar}

A paralisia pseudobulbar é uma síndrome clínica causada pela interrupção das fibras corticunucleares do bulbo para os núcleos motores de nérvos cranianos. $A$ maioria dos núcleos de nérvos cranianos do tronco encefálico recebe inervação bilateral do córtex cerebral, oriundos principalmente do córtex pré-central. A maioria dessas fibras estende-se aos núcleos dos nérvos cranianos por meio da formação reticular. Alguns núcleos de nervos cranianos, entretanto recebem fibras corticonucleares diretamente. Esses núcleos incluem os núcleo sensitivos e motor do trigêmio, o núcleo do trato solitário, o núcleo motor do facial, o núcleo supraespinhal do acessório e núcleo do hipoglosso (AFIFI; BERGMAN, 2005).

A interrupção bilateral das fibras corticuonucleares indiretas ou corticonucleares diretas no tronco encefálico resulata na síndrome da paralisia psudobulbar. As manifestações neurológicas dessa síndrome incluem: Fraqueza dos músculos inervados pelos núcleos de nérvos cranianos correspondentes; execesso de riso e choro. 


\section{ANATOMIA DO TRONCO ENCEFÁLICO (PONTE)}

O metencéfalo consiste na ponte e no cerebelo. A ponte é o segmento médio do troco encefálico, sendo a parte caudal o bulbo e a parte rostral do mesencéfalo. Embora compreendendo apenas uma pequena parte do encéfalo ela é responsável por muitas funcões importantes. Os núcleos motores e sensoriais e os pontos de saída dos V e VIII nervos cranianos.

\subsection{DESENVOLVIMENTO}

O metencéfalo se estende da flexura pontina até $\mathrm{o}$ istmo mesencefálico. A este nível, a cavidade do tubo neural é alargada, formando as partes do quarto ventrículo associadas à ponte e ao cerebelo.

\subsection{PLACAS ALAR E BASAL}

Essas placas se estendem da parte rostral do bulbo até a ponte em desenvolvimento. Os núcleo motores dos nervos cranianos encontrados na ponte (trigêmeo, abducente, facial e salivatório superior) originam-se da placa basal e estão localizados medialmente ao sulco limitante. Os componentes funcionais desses neurônios motores incluem eferentes viscerais especiais (EVE) do trigêmeo e fascial, eferentes somáticos gerais (ESG) do abducente e eferentes viscerais gerais (EVG) do salivatório superior) (HAINES et al., 2006).

Os núcleos sensoriais dos nervos cranianos localizados na ponte incluem as porções dos núcleos do trigêmeo e do vestibulococlear, e a parte rostral do núcleo da trato solitário. Seus componentes funcionais são aferentes somáticos gerais (ASG) para o núcleo trigêmeo, aferentes somáticos especias (ASE) para o núcleo vestibular e coclear, e aferentes viscerais gerais e especiais ( $A V G, A V E$ ) para 0 núcleo do trato solitário. A porção posterior da ponte que contem esses núcleos sensoriais e motores bem como a formação reticular e vários tratos ascendentes e descendentes, é o tegmento da ponte.

A área anterior da ponte em desenvolvimento é invadida por um grande número de fibras corticais descendentes. Embora algumas terminem na ponte mesmo, outras passam para locais mais caudais. Os neurônios imaturos da placa alar também migram para essa região pontina anterior para formar os núcleos basais da ponte. Esses núcleos, seus axônios e as fibras descendentes chegando 
ou passando por esta área formam coletivamente a região basal da ponte (AFIFI; BERGMAN, 2005).

\subsection{ASPECTOS MACROSCÓPICOS DA PONTE}

A ponte situa-se no tronco encefálico entre o bulbo (medula oblonga) inferiormente e o mesencéfalo superiormente. Os pedúnculos cerebrais e o sulco pedunculopontino marcam seu limite superior, os pedúnculos cerebelares médios seu limite lateral e o sulco bulbopontino seu limite inferior. A face posterior da ponte é coberta pelo cerebelo.

a) Face anterior

Essa face forma uma saliência como protuberância pontina (Fig.11). Na linha mediana dessa protuberância está o sulco basilar onde se encontra a artéria basilar. O nervo abducente (VI) emerge pelo sulco bulbopontino. Os nervos facial (VII) e vestibulococlear (VIII) surgem no ângulo entre a parte inferior da ponte e a parte superior da medula oblonga e cerebelo (ângulo pontocerebelar). Da região súperolateral da ponte emergem os dois componentes do nervo trigêmio (V): a grande raíz sensitiva e a pequena raíz motora.

Figura 11-Peça anatômica úmida da face anterior da ponte e mesencéfalo

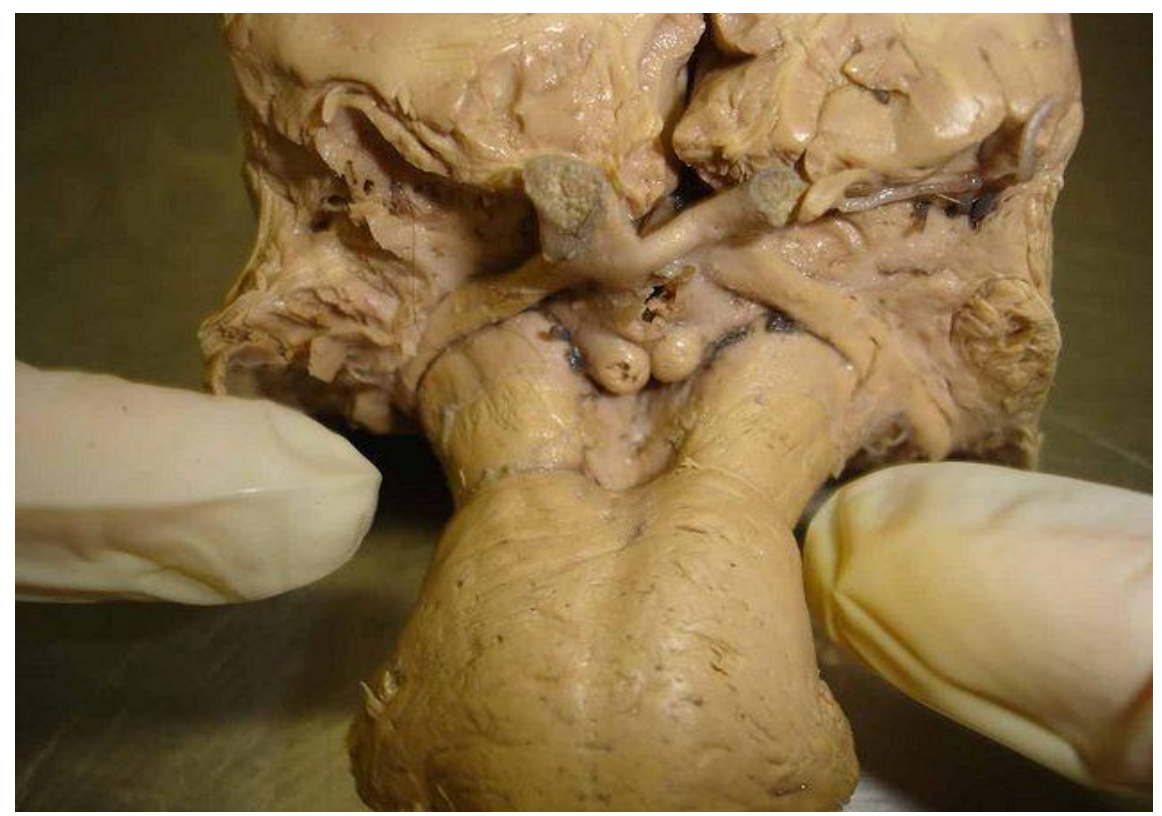

Fonte: Site Didático de Anatomia Pat., Neuropatologia e Neuroimagem (2015) 
a) Face posterior

A face posterior da ponte forma a porção superior do assoalho do quarto ventrículo essa região apresenta como característica a presença dos colículos faciais, um de cada lado do sulco mediano (Fig.12). Esses colículos representam superficilamente o local onde as fibras do nervo facial contornam os núcleos do nervo abducente antes de emegirem do tronco encefálico.

Figura 12-Peça anatômica úmida da face posterior da ponte e bulbo

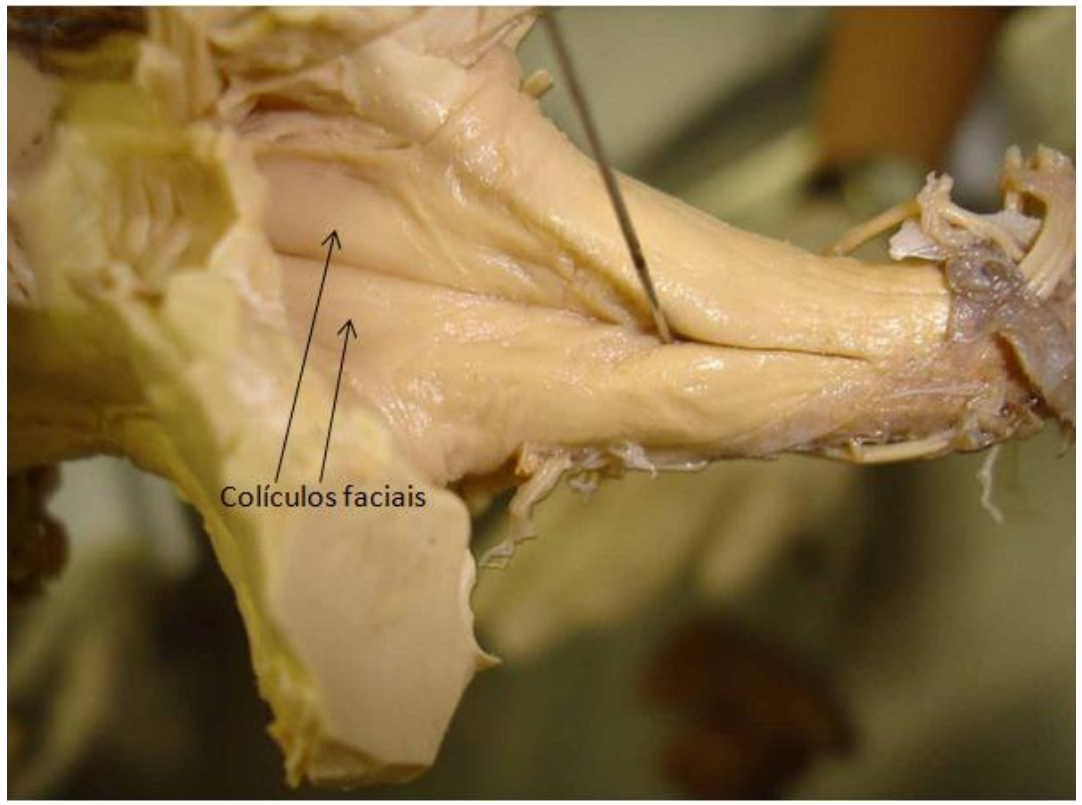

Site Didático de Anatomia Pat., Neuropatologia e Neuroimagem (2015)

\subsection{ASPECTOS MICROSCÓPICOS DA PONTE}

Ao observar secções transversais da ponte podemos ver um padrão de organização básico composto de duas porções: a parte basilar da ponte e o tegmento:

a) Parte basilar da ponte

A parte basilar da ponte corresponde à protuberância pontina. Ela contém os núcleos da ponte e feixes nervosos multidirecionais. Esses feixes pertencem a três sistemas de fibras: 
- Fibras corticoespinhais, que partem do cortex cerebral em direção a medula epinal e atravessam a parte basilar da ponte e continuam inferiormente como pirâmides no bulbo.

- Fibras corticonucleares que partem do córtex cerebral em direção aos núcleos dos nervos cranianos. Algumas destas fibras projetam-se diretamente para os núcleos dos nervos cranianos (corticonucleares e a maioria, entretanto estabelece sinapses em núcleos reticulares intermediários antes de chegar a um núcleo de nervo craniano (corticoreticulonucleares). Geralmente as fibras corticonucleares e corticoreticulonucleares originam-se dos dois hemisférios cerebrais.

- Fibras corticopontocerebelares constituem o maior grupo de fibras na parte basilar da ponte. Esse sistema de fibras origina-se de diversas regiões do córtex cerebral, projeta-se para os núcleos ipsilaterais da ponte e, durante seu trajeto, cruza a linha mediana para chegar ao cerebelo pelo pedúnculo cerebelar médio. Estima-se que em humanos,esse sistema contenha aproximadamente 19 milhões de fibras de cada lado.

O número de neurônios pontinos é avaliado em cerca de 23 milhões em cada lado da ponte. Dessa forma a proporção de fibras corticopontinas para neurônios pontinos e de aproximadamente 1:1. (AFIFI; BERGMAN, 2005).

\subsection{TEGMENTO DA PONTE}

O tegmento da ponte é filogeneticamente a parte mais antiga e é composta basicamente pela formação reticular. Lesões que destroem mais que $25 \%$ do tegmento da ponte podem resultar em perda da consciência. Na região basilar do tegmento, o lemnisco medial torna-se achatado na direção mediolateral. As fibras oriundas do núcleo cuneiforme localizam-se medialmente, enquanto as fibras do núcleo grácil são mais laterais. Lateralmente ao lemnisco medial estende-se o trato espinhal do nervo trigêmeo, que conduz sensibilidade dolorosa, térmica, tátil e proprioceptiva da metade contralateral da face.

O trato espinotalâmico é lateral ao trato espinhal do nervo trigêmeo e conduz sensibilidade dolorosa e térmica da metade contralateral do corpo. Portanto, na região basilar do tegmento está o sistema lemniscal sensitivo, o qual inclui os lemniscos medial e trigeminal, e o trato espinotalâmico. 
Entremeadas com fibras ascendentes do sistema lemniscal há fibras do corpo trapezoide dispostas transversalmente. Essas fibras originam-se dos núcleos cocleares, atravessam o tegmento e agrupam-se na região lateral da ponte para formar o lemnisco lateral.

Posteriormente ao lemnisco medial há o trato tegmental central, que se origina nos núcleos da base e no mesencéfalo e se projeta para o complexo olivar inferior. Troca de posição no tegmento da ponte e estende-se posteriormente à parte lateral do lemnisco medial na região caudal da ponte.

Outros tratos que se estendem pelo tegmento da ponte são o trato rubroespinhal, medial ao núcleo espinhal do nervo trigêmeo, e 0 trato espinocerebelar anterior, medial ao pedúnculo cerebelar inferior. $O$ trato espinocerebelar anterior chega ao cerebelo pelo pedúnculo cerebelar inferior. $O$ tegmento da ponte em sua parte lateral também contém fibras simpáticas descendentes do hipotálamo.

$\mathrm{Na}$ porção superior da ponte, estendendo-se posteriormente ao tegmento existe o locus ceruleus descoberto em 1784 por Félix Vicq-d'Azyr, redescrito por Johann Christian Reil em 1809 e nomeado pelos irmãos Joseph Wenzel and Karl Wenzel em 1812. Cada núcleo deste possui, em média 16.000 a 18.000 neurônios contendo melanina, que estão envolvidos na doença de Parkinson, doença de Alzheimer e síndrome de Down (AFIFI; BERGMAN, 2005). 
Figura 13-Corte axial microscópico da Ponte

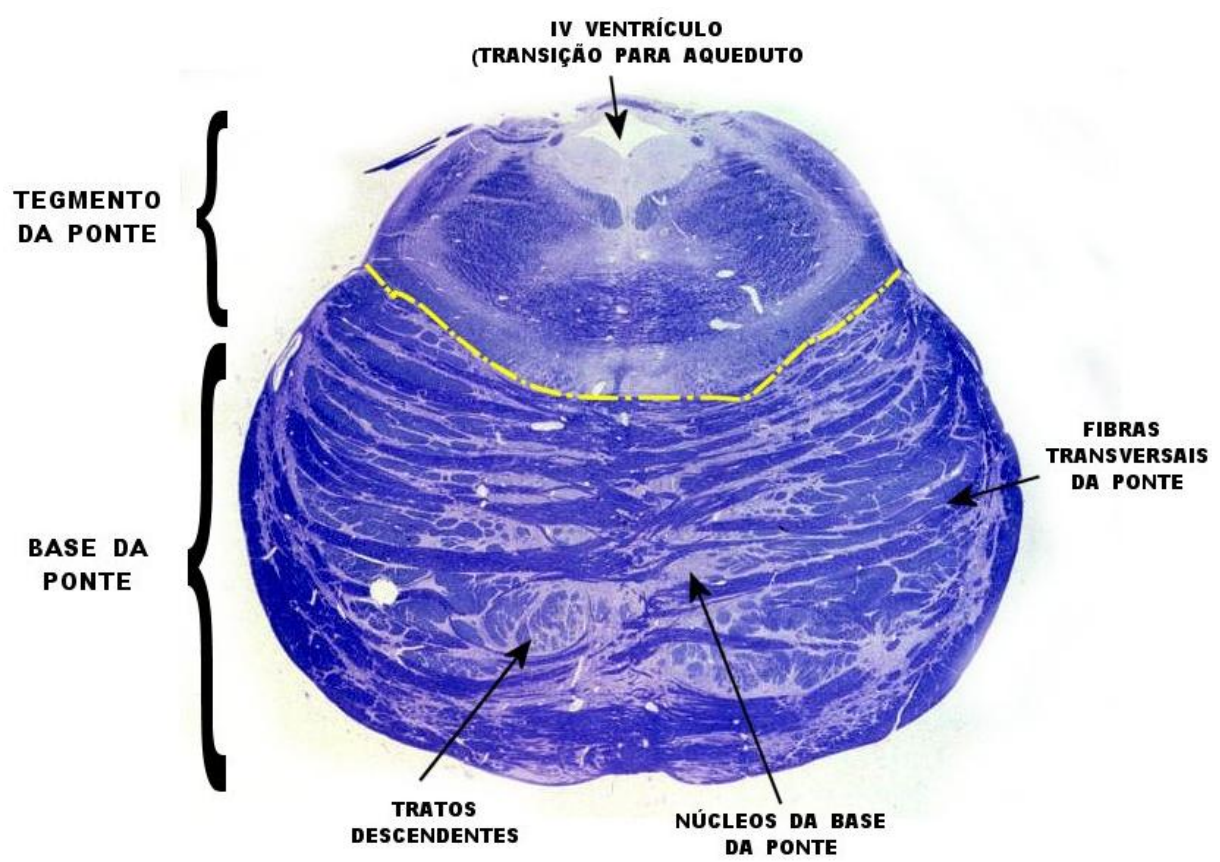

Fonte: Site Didático de Anatomia Pat., Neuropatologia e Neuroimagem (2015)

O locus ceruleus é a principal fonte de inervação noradrenérgica para a maioria das regiões do sistema nervoso central. Esse núcleo é dividido em quatro subnúcleos: central (o maior), superior (extremidade superior), núcleo subcerúleo (inferior e anterior), e um pequeno núcleo inferior e posterior. O núcleo se estende por uma distância rostro-caudal de 11 a $14 \mathrm{~mm}$. Superiormente o núcleo começa no nível do colículo inferior (mesencéfalo), onde está situado anterior e lateral ao aqueduto do mesencéfalo,na substância cinzenta periaquedutal.Inferiormente, na junção do aqueduto de mesencéfalo com o quarto ventrículo, o núcleo desloca-se lateralmente.O número de células no núcleo aumenta de rostral para caudal.Dois feixes de projeção emergem do núcleo:um feixe ascendente dorsal para o hipotálamo, hipocampo, neocortéx e cerebelo,e um feixe descendente para a medula espinhal. A perda celular nesse núcleo é generalizada na doença de Parkinson, mas restrita à parte superior do núcleo na doença de Alzheimer e na síndrome de Down. 


\subsection{FORMAÇÃO RETICULAR DA PONTE}

O termo formação reticular refere-se a um aglomerado de neurônios (corpo e fibra) que se estendem da região caudal do bulbo até a região rostral do mesencéfalo e são contínuos com a zona incerta do subtálamo e com os núcleos medianos, intralaminares e reticular do tálamo. Embora as antigas descrições da formação reticular descrevessem um emaranhado de corpos neuronais e fibras nervosas pouco organizadas, atualmente se sabe que a formação reticular está organizada em grupos nucleares definidos com conexões aferentes e eferentes conhecidas. A formação reticular como um todo compreende um sistema neural com múltiplos influxos e com um sistema multissináptico de condução de impulsos.

\subsubsection{Grupos Nucleares da Formação Reticular}

\subsubsection{Núcleo reticular mediano (núcleos da rafe)}

Lesões que envolvem os núcleos reticulares da ponte no tegmento e as fibras corticoespinhais na parte basilar estão associados à síndrome de anosognosia para hemiplegia, na qual os pacientes não percebem seu déficit motor. Síndrome similar ocorre em lesões do lobo parietal não dominante.

\subsubsection{Núcleo Parabraquial}

No nível do istmo, na região póstero-lateral da ponte entre a margem lateral do pedúnculo cerebelar superior e o lemnisco lateral, está o núcleo parabraquial, uma estação sináptica para as vias gustatórias. Em humanos, o núcleo parabraquial mostrou neurônios catecolaminérgicos contendo neuromelanina. Os neurônios pigmentados do núcleo são pouco menores comparados aos do locus ceruleos, que contém neuromelanina, ou substância negra e seus grânulos possuem aspecto mais discreto. Em humanos o núcleo parabraquial e dividido em segmento lateral e medial. Os neurônios pigmentados são mais abundantes no segmento lateral.

A quantidade de neurônios pigmentados sofre redução significativa em pacientes com doença de Parkinson. O núcleo parabraquial possui conexões com o hipotálamo, amígdalas, estria terminal e núcleos do tronco encefálico, incluindo o 
núcleo do trato solitário e o núcleo posterior da rafe. Acredita-se que o núcleo parabraquial desempenhe importante papel na regulação autônoma, e seu envolvimento no parkinsonismo pode explicar os distúrbios autônomos que ocorrem nessa doença. Estudos em animais e humanos sugerem que o núcleo parabraquial seja uma estação retransmitidora da via gustatória ao tronco encefálico.

\subsubsection{Núcleo Tegmental Pedunculopontino}

O núcleo tegmental pedunculopontino situa-se entre o lemnisco espinhal, pedúnculo cerebelar superior e lemnisco medial. Esse núcleo é o centro de controle do troco encefálico para motricidade somática e comportamentos cognitivos, incluindo locomoção, aprendizagem motora e sistema de recompensa. Várias evidências indicam um papel para esse núcleo no sistema ativador sono-vigília e no mecanismo de coordenação muscular, assim como na função oculomotora, incluindo a iniciação de movimentos sacádicos dos olhos.

O núcleo contém dois grupos de neurônios: colinérgicos e glutamaérgicos. Os eferentes do grupo colinérgico, complexo e amplamente distribuídos, permitem ao núcleo participar de diversas funções. O grupo glutamaérgico projeta-se inferiormente para a formação reticular pontina e bulbar responsável pela locomoção. O núcleo recebe influxos corticais excitatórios diretos de múltiplas áreas do lobo frontal relacionadas à motricidade e influxos inibitórios dos núcleos da base (globo pálido medial e parte reticular da substância negra). O núcleo envia efluxos excitatórios diretos aos núcleos da base e aos núcleos intralaminares do tálamo. Acredita-se que o núcleo tegmental pedunculopontino apresente duas funções:1) servir de estação retransmitidora entre o córtex cerebral e a medula espinhal, atuando como centro de controle para coordenação motora entre os membros; e 2) atuar como centro modulador que recebe impulsos excitatórios do córtex cerebral e controla a atividades de neurônios dopaminérgicos na parte compacta da substância negra influenciando, assim a aprendizagem motora e o sistema de recompensa, assim como o controle motor voluntário. 


\subsection{NÚCLEOS DE NERVOS CRANIANOS PONTINOS}

a) Nervo vestibulococlear (VIII) nervo craniano

O nervo vestibulococlear tem duas divisões: coclear e vestibular. As duas divisões estendem-se paralelamente das terminações periféricas situadas na orelha interna até a ponte, onde se separam e estabelecem conexões próprias distintas

- Divisão coclear: a divisão coclear do nervo vestibulococlear é a maior parte entre as duas partes. As fibras nervosas do nervo coclear são processos centrais de neurônios bipolares do gânglio espiral,situado no modíolo da cóclea na orelha interna. Os processos periféricos desses neurônios bipolares estão conectados às células ciliadas (órgão de Corti).

A medida que as fibras do nervo coclear chegam à parte inferior da ponte, elas entram por sua face lateral, inferior e lateral à divisão vestibular, e projetam-se para os núcleos cocleares posterior e anterior. O núcleo coclear posterior situado na região póstero-lateral do corpo restiforme, recebe fibras originadas nos giros da base da cóclea(mediadores de sons de alta frequência). O núcleo coclear anterior,situado na região ântero-lateral do corpo restiforme, recebe fibras dos giros apicais da cóclea (mediadoras de sons de baixa frequência). O número total de neurônios do núcleo coclear excede bastante o número total de fibras desse núcleo; dessa forma acredita-se que cada fibra projeta-se para vários neurônios. 
Figura 14- Corte axial da ponte evidenciando o tegmento

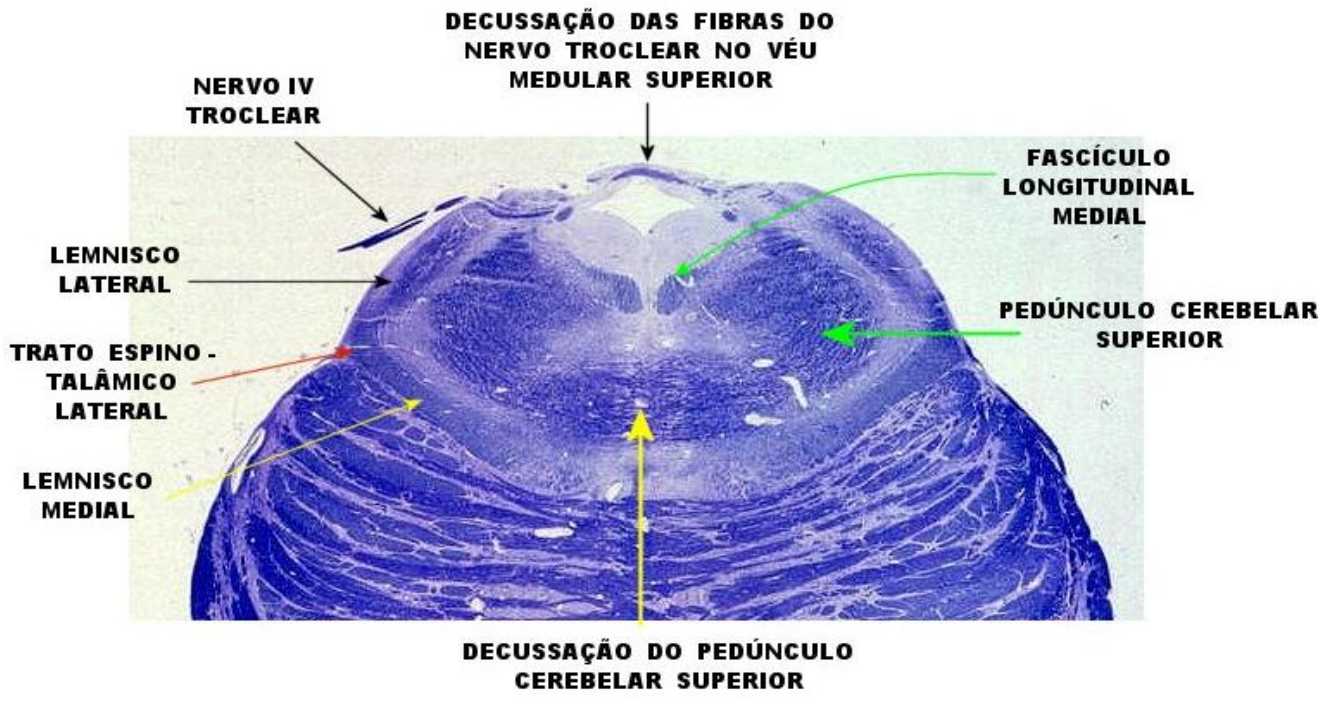

Fonte: Site Didático de Anatomia Pat., Neuropatologia e Neuroimagem (2015)

O neurônios de segunda ordem dos núcleos cocleares estendem-se pelo tegmento da ponte e formam as três estrias cocleares: posterior, anterior e intermédia. A estria coclear posterior é formada por axônios de neurônios situados no núcleo coclear posterior, a estria coclear anterior (corpo trapezóide) é formada por axónios do núcleo coclear anterior, e a estria coclear intermédia origina-se nos núcleos cocleares anterior e posterior. A estria coclear anterior(corpo trapezoide) é a maior das três. Suas fibras projetam-se para os neurônios do complexo olivar superior e núcleo do corpo trapezóide.

O complexo nuclear olivar superior está contido no corpo trapezóide e inclui os núcleos olivares superiores medial e lateral. Os núcleos olivares são agrupamentos celulares alongados de células, dos quais o núcleo olivar superior medial e mais desenvolvido em humanos enquanto o núcleo olivar superior lateral e o núcleo do corpo trapezoide, consiste em pequenas células situadas na metade inferior do núcleo olivar superior, são pouco desenvolvidos. Os dois núcleos olivares superiores e o núcleo do corpo trapezóide são circundados por uma área de células de diversos tamanhos e formas conhecidas coletivamente como núcleos periolivares. Acreditava-se, inicialmente, que esses núcleo periolivares estivessem envolvidos exclusivamente com as vias acústicas descendentes, porém verificou-se que as células estão envolvidas com projeções acústicas descendentes e ascendentes. As funções do complexo olivar superior incluem:1)processamento de 
sinais cocleares pela via acústica ascendente;2)detecção da intensidade sonora interaural e 3) proporcionar controle por feedback do mecanismo coclear, por meio do trato olivar. As estações subsequentes na via acústica incluem sinapse no colículo inferior e no corpo geniculado (AFIFI; BERGMAN, 2005).

O colículo inferior é o retransmitidor mais importante nas projeções acústicas ascendentes e descendentes. Ele consiste em um núcleo central grande e compacto e em uma região mais difusa situada lateralmente. A maioria das fibras acústicas ascendentes para o colículo inferior termina no núcleo central. A região lateral do colículo inferior recebe aferentes do núcleo central, assim como do núcleo do lemnisco lateral. Há evidências de que o núcleo olivar superior medial ipsilateral e o núcleo olivar superior lateral contralateral enviem projeções excitatórias ao núcleo central do colículo inferior, enquanto o núcleo olivar superior lateral ipsilateral envia projeções inibitórias a este núcleo. Apenas um número limitado de fibras contidas na projeção acústica ascendente não passa pelo colículo inferior para chegar diretamente ao corpo geniculado medial. Essas fibras em geral se originam dos núcleos cocleares e do núcleo do lemnisco lateral. Os dois colículos inferiores conectam-se entre si pela comissura do colículo inferior e ao corpo geniculado medial pelo braço do colículo inferior.

A estação final é o córtex acústico primário(giros transversos de Heschl) no lobo temporal. A projeção acústica (radiação acústica) do corpo geniculado medial ao córtex acústico primário estende-se pela parte sublentiforme da cápsula interna. A radiação acústica é subdividida progressivamente, do nível do colículo inferior ao córtex acústico primário, em projeções central e periférica. A projeção central termina no córtex acústico primário; a projeção periférica termina em áreas corticais circunjacentes ao córtex acústico primário. As projeções centrais e periféricas também possuem áreas de origem distintas no colículo inferior, onde o núcleo central está relacionado à projeção central e a zona lateral à projeção periférica. A organização tonotópica está presente em todo sistema acústico.

Além desta via acústica clássica, evidências sugerem haver outra via acústica multissináptica através da formação reticular. A evidência de via reticular baseia-se em várias observações experimentais.

- Divisão vestibular: as fibras do nervo vestibular são processos centrais de células bipolares situadas no gânglio vestibular (gânglio de Scarpa). Os processos periféricos dessas células bipolares estendem-se às terminações nervosas 
vestibulares situadas nos três ductos semicirculares, no utrículo e no sáculo. Os dúctos semicirculares estão relacionados a aceleração angular; o utrículo e o sáculo estão relacionados à aceleração linear. A porção superior do gânglio vestibular recebe fibras dos ductos semicirculares anterior e lateral, do utrículo e do sáculo.

A porção inferior do gânglio recebe fibras do ducto semicircular posterior e do sáculo. O nervo vestibular acompanha o nervo coclear do meato acústico interno até a ponte, onde penetra pela face lateral, no sulco bulbopontino, medialmente ao nervo coclear. No interior da ponte, as fibras do nervo vestibular estendem-se pelo tegmento entre o corpo restiforme e o complexo espinhal do nervo trigêmeo.

A porção maior destas fibras projeta-se para os quatro núcleos vestibulares; a porção menor estende-se diretamente ao cerebelo através do corpo justarestiforme. No cerebelo, essas fibras terminam como fibras musgosas em contato com os neurônios do lobo flóculo-nodular e da úvula. Existem quatro núcleos vestibulares: medial, inferior, lateral e superior. O núcleo medial (principal) aparece no bulbo, na extremidade superior do complexo olivar inferior, e estende-se à parte inferior da ponte. O núcleo inferior (núcleo espinhal) estende-se entre o núcleo medial e o corpo restiforme. O núcleo inferior, que aparece atravessado por fibras mielínicas do nervo vestibular, estende-se da extremidade superior do núcleo grácil a junção bulbopontina. O núcleo lateral e caracterizado por grandes neurônios multipolares estende-se da junção bulbopontina ao nível do núcleo do abducente. O núcleo superior é menor que os outros núcleos e estende-se posterior e medialmente aos núcleos medial e lateral (AFIFI; BERGMAN, 2005).

\subsubsection{Nervo Facial (VII Nervo Craniano)}

O nervo facial é misto apresentando componentes sensitivos e motores. Esse nervo é responsável pelas expressões facial que caracteriza cada um de nós.

a) Componente sensitivo

O nervo facial possui dois tipos de componente sensitivo:

- Fibras exteroceptivas provenientes da orelha externa e fibras gustatórias dos dois terços anteriores da língua. As fibras exteroceptivas da orelha externa são processos periféricos de neurônios situados no gânglio geniculado. Os processos centrais projetam-se para os neurônios do núcleo espinhal do nervo trigêmeo. 
- As fibras gustatórias apresentam os corpos neuronais de origem situados no gânglio geniculado. Os processos periféricos desses neurônios chegam as papilas gustatórias situadas nos dois terços anteriores da língua; os processos centrais adentram o tronco encefálico com o nervo intermédio e projetam-se para os neurônios situados na parte gustatória do núcleo do trato solitário, juntamente com fibras dos nervos glossofaríngeo e vago. As fibras exteroceptivas e gustatórias, junto com componente motor visceral, constituem uma raiz lateral separada do nervo facial, o nervo intermédio.

b) Componentes motores

O nervo facial possui dois tipos de fibras motoras: somática e secretora motora.

\section{- Fibras motoras somáticas}

As fibras motoras somáticas inervam os músculos da face, estapédio, estilohióideo e ventre posterior do digástrico. Essas fibras originam-se no núcleo do nervo facial, situada no tegmento da ponte.

A partir de corpos neuronais de origem as fibras se estendem póstero medialmente e, em seguida superiormente no tegmento para formar um feixe compacto próximo do núcleo de nervo abducente no assoalho do quarto ventrículo formando o colículo facial. As fibras do facial se curvam fomando o joelho lateralmente sobre o núcleo do nervo abducente e estende-se ântero-lateralmente para emergir na margem lateral da ponte.

Esse trajeto peculiar do componente motor somático das fibras no nervo facial no tegmento resulta da migração ântero-inferior dos neurônios motores faciais, a partir de uma posição posterior no assoalho do quarto ventrículo levando os axônios consigo. A migração do núcleo do nervo facial é explicada pela neurobiotaxia, em que os neurônios tendem a migrar em direção às principais fontes de estímulo.

No caso do núcleo do facial, essa migração o conduz para perto do núcleo e trato espinhal do nervo trigêmeo. Os componentes sensitivos e motores viscerais do nervo facial não constituem a alça em torno do núcleo do nervo abducente. Em vez disso, eles formam um raiz lateral separada do nervo facial, o nervo intermédio.

O núcleo do nervo facial é organizado em colunas motoras orientadas longitudinalmente (subnúcleos) relacionadas a músculos faciais específicos: os subnúcleos medial, posterior, intermédio e lateral. Os neurônios superiores inervam 
os músculos superiores da face e localizam-se na parte posterior do núcleo, os que ineravam os músculos inferiores da face situam-se, principalmente, na parte lateral do núcleo, e os que inervam o platisma o músculo auricular posterior estão na parte medial do núcleo.

-Fibras secretomotoras. Essas fibras originam-se do núcelo salivatório superior o tegmento da ponte. São fibras pré-ganglionares que deixam o tronco encefálico com o nervo intermédio e estabelecem sinapses em gánglios colaterais.

As fibras destinadas à glândula lacrimal deixam o nervo intermédio e estendem-se pelo nervo petroso maior e nervo vidiano antes de fazer sinapse no gânglio pterigopalatino, a partir do qual fibras pós-ganglionares estendem-se pelos nervos maxilar, zigomático, zigomaticotemporal e lacrimal para chegar a glândula lacrimal. As fibras destinadas às glândulas submandibular e sublingual juntam-se a corda do tímpano e ao nervo lingual para estabelecer sinapses no gânglio submandibular.

Considerando que as fibras para as glândulas lacrimal, submandibular e sublingual saem juntas do tronco encefálico, as lesões do nervo facial próximas ao gânglio geniculado podem resultar de crescimento aberrante de fibras em regeneração, de forma que as fibras destinadas à inervação da glândula lacrimal chegam as às glândulas salivares sublingual e submandibular. Esse crescimento aberrante é responsável pelo fenômeno das "lágrimas de crocodilo", em que a presença de alimento na boca é seguida por lacrimejamento em vez de salivação (AFIFI; BERGMAN, 2005).

O nervo facial recebe fibras dos seguintes sítios:

a) córtex cerebral

Fibras corticofaciais originam-se da áreas de representação da face nos córtices motor primário, motor suplementar, pré motor,cingulado anterior e posterior. Essas fibras projetam-se como fibras corticonucleares diretas ou corticonucleares indiretas. O influxo cortical ao núcleo do nervo facial é bilateral para a parte do núcleo que inerva os músculos superiores da face e apenas contralateral para a parte que inerva a musculatura perioral. Em lesões que afetam um hemisfério cerebral, são comprometidos apenas os músculos inferiores da face, contralaterais à lesão. Isso se denomina paralisia facial central(supra nuclear), ao contrário da 
paralisia ou paresia facial periférica que resulta de lesão no nervo ou núcleo facial, na qual todos os músculos da face ipsilaterais a lesão são afetados.

b) Núcleo da base

Esse influxo para o núcleo do nervo facial explica o movimento de músculos da face paréticos em resposta ao estímulo emocional. Pacientes com paralisia facial central,incapazes de contrair de forma voluntária os músculos inferiores da face. Podem fazê-lo reflexamente em resposta a um estímulo emocional.

c) Núcleo olivar superior

Esse influxo é parte de um reflexo que envolve os nervos faciais e vetibulococlear. Isso explica as expressões de careta proporcionadas pelos músculos da face em resposta a um barulho intenso. Sistema trigeminal. Esse influxo também é de natureza reflexa, envolvendo os nervos trigêmeos e facial. Ele explica o ato de piscar os olhos em resposta a um estímulo na córnea.

c) Colículo superior

Esse influxo, através de fibras tetobulbares, é de natureza reflexa e proporciona o fechamento da pálpebras em resposta à luz intensa ou a um objeto que se aproxima rapidamente.

\subsection{NERVO ABDUCENTE(VI NERVO CRANIANO)}

O nervo abducente é puramente motor e inerva o músculo reto lateral do bulbo ocular. O núcleo do nervo abducente localiza-se em posição paramediana no tegmento da ponte, no assoalho do quarto ventrículo. Estende-se do limite superior do núcleo vestibular lateral à porção superior do núcleo vestibular inferior. O núcleo do nervo abducente possui duas populações neuronais: grande (neurônios motores) e pequena (interneurônios).

Os axônios dos neurônios motores formam o nervo abducente e inervam o músculo reto lateral. Os axônios dos interneurônios juntam-se ao fascículo longitudinal medial contralateral e terminam em contato com neurônios do subnúcleo do reto medial do núcleo do nervo oculomotor. Os axônios do nervo 
abducente estendem-se pelo tegmento e parte basilar da ponte para saírem por sua face anterior no sulco bulbo pontino.

O núcleo do nervo abducente recebe fibras: 1) córtex cerebral; 2) do núcleo vestibular medial através do fascículo longitudinal medial; 3) da formação reticular pontina paramediana (FRPP); e 4) do núcleo prepósito do hipoglosso. O influxo corticonuclear é bilateral e o influxo da FRPP e do núcleo prepósito não são cruzados, e o influxo do núcleo vestibular medial é predominantemente não cruzado. Relatam-se fibras aferentes diretas do gânglio vestibular para o núcleo do nervo abducente.

Lesões do nervo abducente resultam em paralisia ipsilateral do músculo reto lateral e diplopia na tentativa de direcionar o olhar horizontal para o lado do músculo paralisado. Ao contrário das lesões do nervo abducente,as lesões de seu núcleo não resultam em paralisia da abdução, mas em paralisia do olhar horizontal ipsilateral à lesão; isso se observa pela deficiência de movimento de ambos os olhos durante o olhar horizontal ipsilateral (AFIFI; BERGMAN, 2005).

\subsection{NERVO TRIGÊMEO (V NERVO CRANIANO)}

O nervo trigêmeo é o maior dos doze nervos cranianos. Transmite informação sensitiva da cabeça e do pescoço e inerva os músculos da mastigação, o tensor do tímpano, o tensor do véu palatino, o milo-hióideo e o ventre anterior do digástrico. 0 nervo trigêmeo possui duas raízes; uma raiz motora (porção menor) e uma raiz sensitiva (porção maior). A raiz motora é composta de até 14 radículas individualizadas que se fundem a cerca de $1 \mathrm{~cm}$ da ponte. Na ponte a primeira divisão da raiz sensitiva (V1) está localizada geralmente em posição póstero-medial, junto à raiz motora e a terceira divisão (V3) em posição ínfero-lateral. No entanto, a divisão V3 varia de posição totalmente inferior e totalmente lateral.

Radículas sensitivas aberrantes estão presentes em aproximadamente 50\% dos indivíduos e podem explicar a persistência de dor facial (neuralgia do trigêmeo) após secção cirúrgica da raiz sensitiva. As radículas sensitivas aberrantes entram na raiz sensitiva até $1 \mathrm{~cm}$ da ponte e contribuem principalmente para formação de $\mathrm{V} 1$. Algumas radículas entre as raízes sensitiva e motora podem entrar em qualquer 
uma destas raízes bem mais distante da ponte. Foram descritas conexões entre a raiz sensitiva e a motora, que podem explicar a dificuldade de se aliviar a dor ao seccionar-se a raiz sensitiva.

a) Raiz motora

A raiz motora do nervo trigêmeo origina-se do núcleo motor deste nervo no tegmento da ponte. A raiz motora inerva os músculos da mastigação, o tensor do tímpano, o tensor do véu palatino, o milo-hióideo e o ventre anterior do digástrico. 0 núcleo motor recebe fibras do córtex cerebral e dos núcleos sensitivos do trigêmeo. As projeções corticais para os neurônios motores do trigêmeo são bilaterais e simétricas, por meio de fibras corticonucleares diretas e corticonucleares indiretas. Lesões que afetam o núcleo motor ou a raiz motora resultam em paralisia, do tipo neurônio motor inferior, dos músculos inervados por esta raiz.

b) Raiz sensitiva

A raiz sensitiva do nervo trigêmeo contém dois tipos de fibras aferentes:

- Fibras proprioceptivas. São fibras proprioceptivas de estruturas profundas da face estendem-se através das raízes sensitiva e motora. São processos periféricos de neurônios unipolares do núcleo mesencefálico do nervo trigêmeo, situado no nível superior da ponte e inferior do mesencéfalo. Esse núcleo é único, pois apesar de ser homólogo ao gânglio sensitivo dos nervos espinhais, localiza-se centralmente. As fibras proprioceptivas para o núcleo mesencefálico conduzem informação de pressão e cinestesia dos dentes, periodonto, palato duro e cápsulas articulares, assim como impulsos dos receptores de estiramento dos músculos da mastigação. O efluxo do núcleo mesencefálico é destinado ao cerebelo, tálamo, núcleos motores do tronco encefálico e formação reticular. O núcleo mesencefálico está relacionado a mecanismos que controlam a força da mordida.

-Fibras exteroceptivas. São fibras sensitivas somáticas gerais que conduzem sensibilidade dolorosa, térmica e tátil da face e região anterior da cabeça. Os corpos neuronais de origem dessas fibras estão situados no gânglio trigeminal. Os processos periféricos desses neurônios estendem-se pelas três divisões do nervo trigêmeo. (AFIFI; BERGMAN,2005). 


\subsection{SUPRIMENTO SANGUÍNEO DA PONTE}

O suprimento sanguíneo da ponte é derivado da artéria basilar. Três grupos de vasos fornecem sangue as regiões específicas da ponte: paramedianos e circunferenciais curto e longo.

a) Os vasos paramedianos originam-se da artéria basilar e entram pela face anterior da ponte, irrigando a região medial da parte basilar da ponte e tegmento. Os núcleos da ponte e os tratos corticoespinhais, no interior da parte basilar da ponte, e o lemnisco medial estão entre as estruturas supridas por esses vasos.

b) Os ramos circunferenciais curtos originam-se da artéria basilar, adentram o pedúnculo cerebelar médio e irrigam a região ântero-lateral da parte basilar da ponte.

c) Os ramos circunferenciais longos incluem a artéria cerebelar inferior anterior ( $\mathrm{ACIA})$, a artéria do labirinto e a artéria cerebelar superior.

A ACIA irriga a parte lateral do tegmento dos dois terços inferiores da ponte, assim como a porção ântero-lateral do cerebelo. A artéria do labirinto, oriunda da ACIA ou da artéria basilar irriga os nervos vestibulococlear e facial. A artéria cerebelar superior irriga a região póstero-lateral da ponte, os pedúnculos cerebelares médio e superior e a formação reticular dorsal. Ocasionalmente, a região ântero-lateral do tegmento da ponte também é suprida por este vaso (AFIFI; BERGMAN, 2005).

\subsection{CORRELATOS CLÍNICOS DA PONTE}

\subsubsection{Síndromes pontinas basilares}

As síndromes pontinas basilares são causadas por lesões que afetam as radículas de nervos cranianos e o trato corticoespinhal na parte basilar da ponte.

a) Síndromes pontinas basilares inferiores

- Síndrome de Millard-Gubler: a manifestações desta síndrome,originalmente descrita por Millard e Gubler em 1856, incluem paralisia facial ipsilateral do tipo periférico e hemiplegia contralateral do tipo neurônio motor superior. 
Frequentemente, a lesão se estende medial e superiormente.afetando radículas do sexto nervo craniano. Nesse caso,o paciente também mostra sinais de paralisia ipsilateral do sexto nervo.

Fig.15-A) IRM Axial T1 B) Axial T2 CISS. Mostrando área hipodensa na parte ventral esquerda da ponte ( sindrome Millard-Gubler):
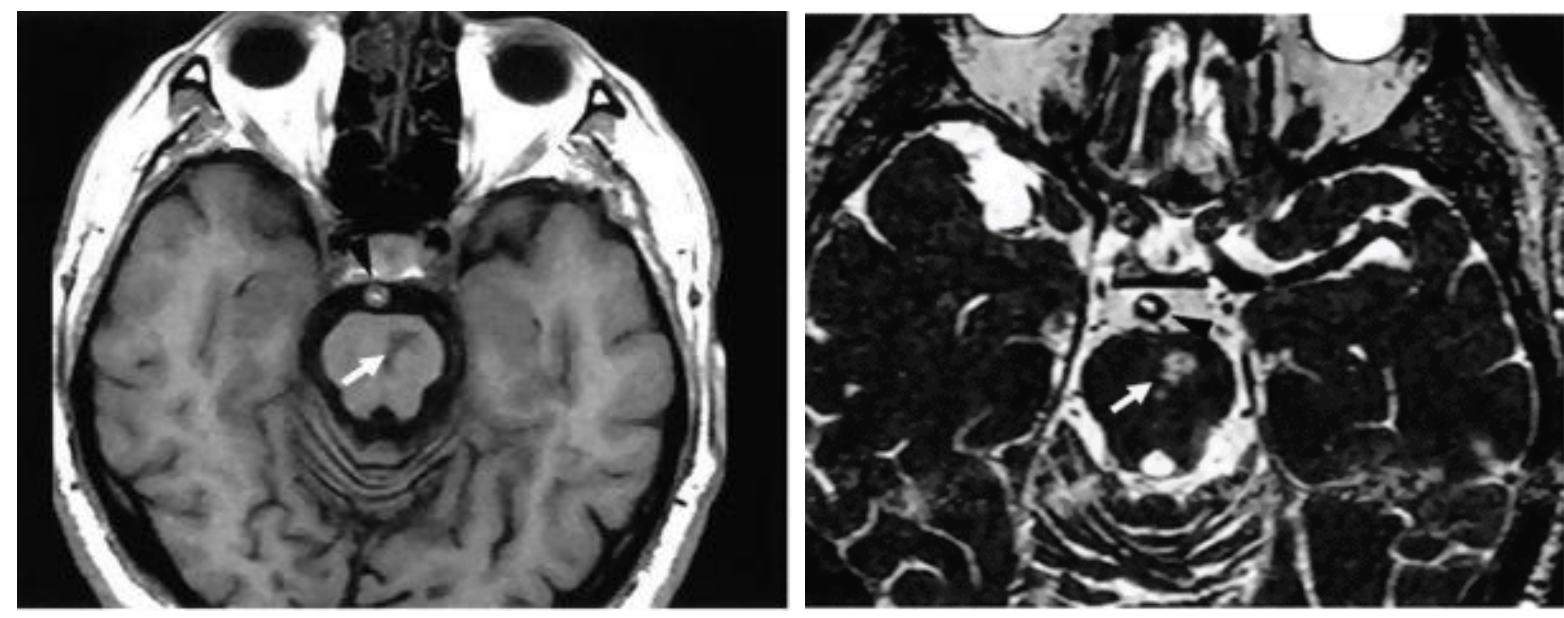

Fonte: Omer, Kantarci, Alper, Karaca (2005).

b) Síndrome de Gellé: descrita em 1901, a síndrome de Gellé consiste em surdez ipsilateral, vertigem,paralisia facial variável e hemiparesia contralateral. A lesão ocorre na região ântero-lateral da parte inferior da ponte e envolve o nervo vestibulococlear e fibras do trato corticoespinhal com comprometimento variável do nervo facial.

c) Síndrome de Webino (estrabismo cruzado): síndrome de Webino ou síndrome da oftalmoplegia internuclear bilateral exotrópica. A lesão envolve a porção rostral do fascículo longitudinal medial causada na maioria das vezes por infarto ou esclerose múltipla. A síndrome é caracterizada por desvio lateral dos dois olhos(olhar exotrópico) e ausência de adução ocular. 
Figura.16- IRM FLAIR axial do tronco encefálico no terceiro dia de hospitalização. A seta mostrou uma pequena região, hiper-intensa no lado direito do tegmento da ponte. Outras imagens do mesencéfalo e outra seção de ponte não mostram nenhuma anormalidade.

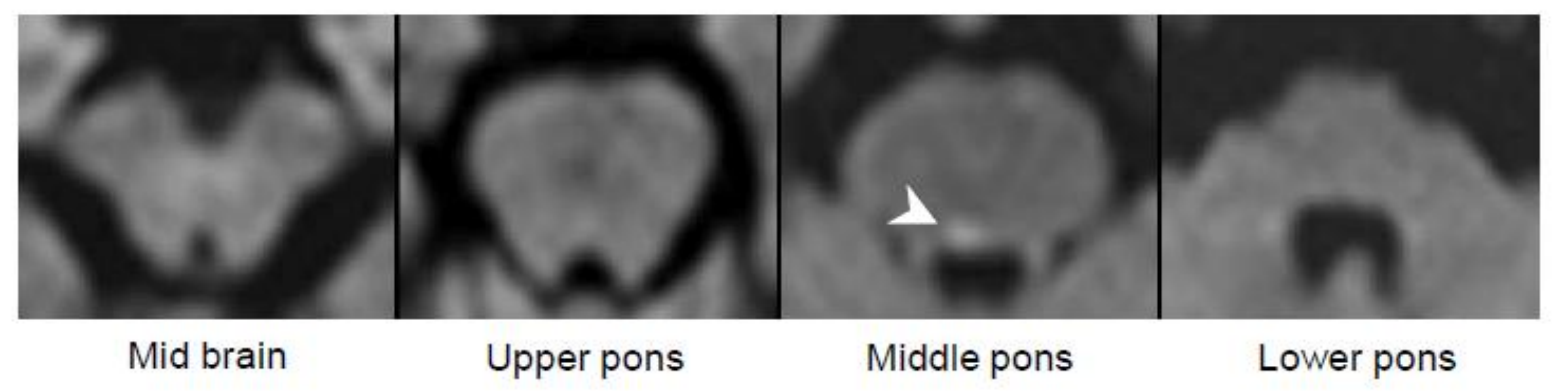

Fonte: Yoshinaga, Nakamura, Kaneko, (2010).

d) Síndrome de Brissaud-Sicard: descrita em 1906, a síndrome consiste em hemiespasmo facial ipsilateral e hemiparesia contralateral. A lesão ocorre na região ântero-inferior da ponte e envolve as radículas do nervo facial e fibras do trato córtico espinhal.

Figura. 17- A) IRM axial difusão. B) Axial T2 evidenciando área de infarto pontino ântero inferior
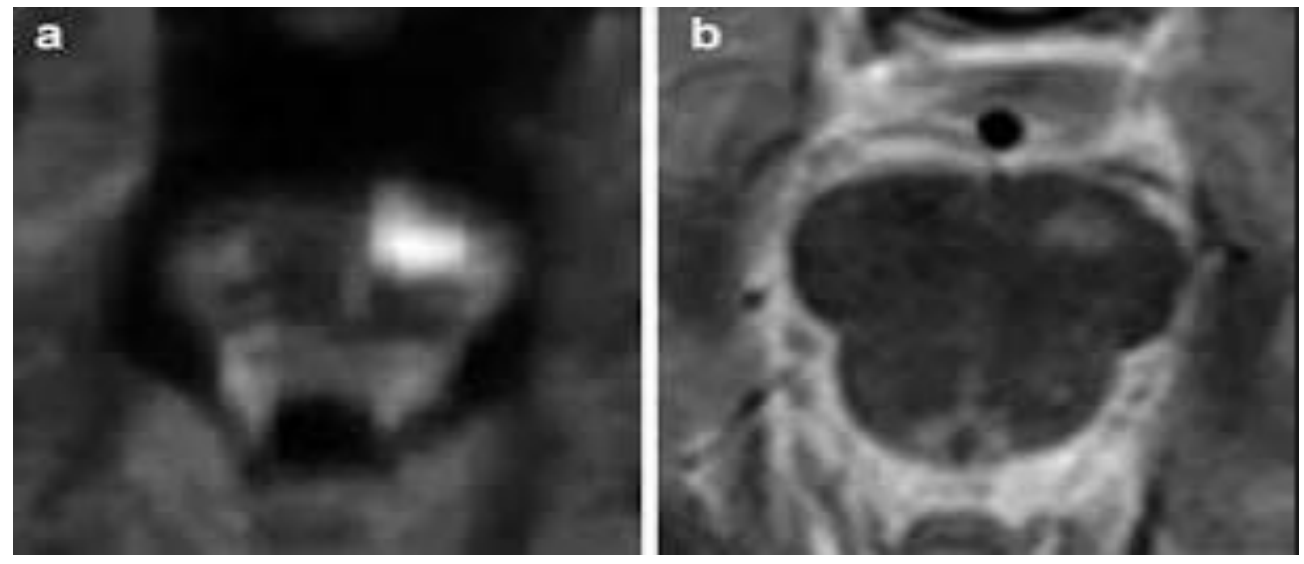

Fonte: Urban e Caplan (2011).

e) Síndrome de disartria- Mão desajeitada: lesões vasculares na junção do terço superior com os dois terços inferiores da parte basilar da ponte foram associados à síndrome de disartria-mão desajeitada. Essa síndrome caracteriza-se por fraqueza facial central, disartria e disfagia graves, paresia e desjeito da mão. 
f) Síndrome de encarceramento: a síndrome de encarceramento é uma síndrome pontina basilar grave e incapacitante que ocorre devido a um infarto na metade anterior da ponte. Nessa síndrome há paralisia de toda a atividade motora decorrente de comprometimento dos tratos corticoespinhais na parte basilar da ponte e afonia causada pelo comprometimento de fibras corticonucleares que se estendem pela parte basilar da ponte. O olhar vertical e o piscar de olhos são preservados e constituem o único meio pelo qual os pacientes se comunicam. Tais pacientes são descritos como "cadáveres com olhos vivos". (AFIFI; BERGMAN, 2005).

\subsubsection{Síndromes pontinas tegmentais}

As síndromes pontinas tegmentais são causadas por lesões no tegmento da ponte que afetam núcleos ou radículas de nervos cranianos e longos tratos no tegmento.

\subsubsection{Síndrome tegmental medial}

As estruturas afetadas na síndrome tegmental medial incluem o núcleo e as radículas do nervo abducente, o joelho do nervo facial e o lemnisco medial. As manifestações da lesão incluem, portanto paralisia ipsilateral do sexto nervo e paralisia do olhar lateral, paralisia facial ipsilateral do tipo periférico e perda contralateral de cinestesia e tato discriminativo

\subsubsection{Síndrome pontina tegmental póstero-lateral}

Relatou-se lesões vasculares na região póstero-lateral do tegmento da ponte, que afetam estruturas irrigadas pela artéria cerebelar inferior anterior ( $\mathrm{ACI} A)$ em um lado, combinadas com uma lesão vascular na região póstero-lateral do bulbo, que afeta estruturas irrigadas pela artéria cerebelar inferior posterior (ACIP) em outro lado, causam perda sensitiva dissociada abrangendo o corpo todo, acompanhada por ataxia de membros e tronco sem fraqueza. A perda sensitiva dissociada ocorre por comprometimento simultâneo e bilateral do tratos espinotalâmicos e do sistema trigeminal com preservação do sistema lemniscal. A ataxia se deve ao comprometimento de fibras destinadas ao cerebelo que se estendem pelo tegmento ou no próprio cerebelo. 


\subsubsection{Síndromes pontinas tegmentais inferiores}

a) Síndrome de Foville: caracteriza-se por paralisia facial periférica, paralisia do olhar horizontal ipsilateral e hemiparesia contralateral. Em geral, a lesão situa-se na região inferior da ponte e envolve o trato corticoespinhal, a formação reticular pontina paramediana e ou o núcleo do nervo abducente,assim como o núcleo ou fibras do nervo facial (fraqueza dos músculos da face

b) Alucinose musical: lesões laterais ou paramedianas no tegmento da parte inferior da ponte foram associadas à alucinose musical. As melodias ou sons musicais geralmente são familiares. Em geral, a lesão envolve uma ou mais das seguintes estruturas acústicas: estrias cocleares (incluindo o corpo trapezóide), núcleo olivar superior e lemnisco lateral. Além disso, a lesão envolve fibras do nervo trigêmeo destinadas ao músculo estapédio, ambas se estendendo pela porção inferior da ponte. As alucinações são atribuídas à evocação de memórias acústicas por meio da desinibição de vias reticulares do núcleo pontino da rafe para centros sensitivos do tálamo e córtex cerebral.

\subsubsection{Síndrome pontina tegmental média (síndrome de Grenet)}

Descrita por Grenet em 1856, essa síndrome consiste em termoanalgesia em ambos os lados da face e metade contralateral do tronco, com comprometimento motor ipsilateral do nervo trigêmeo (paralisia dos músculos da mastigação), ataxia, tremor e hemiparesia contralateral. A lesão situa-se no tegmento da porção média da ponte, envolve núcleos do nervo trigêmeo, fibras trigeminotalâmicas, pedúnculo cerebelar superior e trato espinotalâmico e estende-se anteriormente para atingir fibras corticoespinhais

\subsubsection{Síndrome pontina tegmental lateral (Síndrome de Marie- Foix)}

Na síndrome de Marie-Foix ocorre ataxia cerebelar ipsilateral e hemiparesia contralateral com ou sem perda sensitiva. A lesão ocorre na porção superior da região lateral extrema da ponte envolvendo o pedúnculo cerebelar médio (ataxia), o trato espinotalâmico (perda hemissensitiva) e o trato corticoespinhal (hemiparesia). O quadro clínico completo da síndrome de Maria-Foix raramente é observado e 
inclui paralisias ipisilaterais de nervos cranianos, síndrome de Horner, hemiataxia, mioclônus palatal e perda sensitiva espinotalâmica contralateral.

\subsection{PONTE E RESPIRAÇÃO}

Existem dois tipos de respiração: voluntária e automática. Ocorre perda seletiva de respiração voluntária em pacientes com lesão na parte basilar da ponte. Também se descreveu perda seletiva da respiração voluntária ou automática como parte da síndrome de encarceramento.

Supõe-se que as vias respiratórias automáticas iniciem-se no córtex límbico e envolvam estruturas diencefálicas, o sistema reticular do tronco encefálico, a porção lateral ou posterior da ponte, os núcleos bulbares mediadores da respiração automática e os neurônios respiratórios da medula espinhal. A perda seletiva de respiração automática ocorre em pacientes com a Síndrome de Ondine, lesões do bulbo ou lesões bilaterais da parte cervical superior da medula espinhal (AFIFI; BERGMAN, 2005). 


\section{ANATOMIA DO TRONCO ENCEFÁLICO (MESENCÉFALO)}

O mesencéfalo é a porção mais rostral do tronco cerebral. Ele dá origem aos III e IV nervos cranianos, conduz tratos ascendentes e descendentes e contém núcleos que são essenciais para função motora. Caudalmente, o mesencéfalo é contínuo com a ponte e rostralmente une-se ao diencéfalo. O aqueduto cerebral, a cavidade do mesencéfalo é contínua rostralmente com o terceiro ventrículo e caudalmente com o quarto ventrículo. O suprimento sanguíneo para o mesencéfalo é feito primariamente por meio de ramos proximais das artérias cerebrais posteriores (P1 ou P2) e por pequenos ramos penetrantes da comunicante posterior.

\subsection{DESENVOLVIMENTO DO MESENCÉFALO}

O mesencéfalo tem origem no início do desenvolvimento como uma das três vesículas cerebrais primárias. Neurônios imaturos, que surgem da zona ventricular para penetrar e formar a zona intermediária, dão origem às placas alar e basal, que são contínuas com as placas alar e basal do rombencéfalo. Esses grupos celulares são as continuações rostrais das mesmas colunas de células primitivas descritas para o metencéfalo. A camada marginal circundante contém os axônios em desenvolvimento das células localizadas em outros níveis do eixo neuronal. 0 aqueduto cerebral é estreito em relação ao quarto ventrículo; portanto, as placas basal e alar se localizam anterior e posteriormente a esta estrutura, assim como na medula espinhal e na medula oblonga.

a) Placas basal e alar

Os neurônios imaturos da placa alar dão origem à lámina quadrigeminal, de onde se originam os colículos superior e inferior. Em humanos o colículo superior consiste em camadas alternadas de células e fibras, enquanto o colículo inferior parece mais homogêneo, mas é formado por um grande núcleo central e vários pequenos núcleos localizados na periferia. Os neurônios imaturos da placa alar também migram para as áreas anteriores do mesencéfalo em desenvolvimento para formar o núcleo rubro e a substância negra.

Os neurônios imaturos da placa basal dão origem aos neurônios somáticos eferentes gerais dos núcleos oculomotor e troclear. Além disso, as células viscerais 
eferentes gerais do núcleo de Edinger-Westphal, um grupo de células motoras viscerais associadas ao complexo oculomotor, também se originam na placa basal.

A medida que as placas basal e alar se diferenciam, a camada marginal é invadida por axônios que se originam de células localizadas fora do mesencéfalo. Essas fibras se unem na área ântero-lateral do mesencéfalo em desenvolvimento para formar um fascículo especialmente proeminente, o pedúnculo cerebral. (HAINES et al, 2006).

\subsection{ASPECTOS MACROSCÓPICOS DO MESENCÉFALO}

a) Face anterior

A face anterior do mesencéfalo é marcada pela divergência de dois feixes maciços de fibras, os pedúnculos cerebrais que possuem fibras corticofugais para níveis inferiores. Inferiormente, os pedúnculos cerebrais chegam à parte basilar da ponte; superiormente continuam com a cápsula interna. Entre os pedúnculos cerebrais está a fossa interpeduncular, da qual emerge o nervo oculomotor (III nervo craniano). O nervo troclear (IV) emerge da região posterior do mesencéfalo, contornando-o para surgir nas margens laterais dos pedúnculos cerebrais. $\mathrm{O}$ trato óptico passa sobre os pedúnculos cerebrais antes que estes penetrem no interior do hemisfério cerebral.

b) Face posterior

A face posterior do mesencéfalo apresenta quatro saliências chamadas de colículos ou corpos quadrigêmeos. Os maiores e mais rostrais são os colículos superiores; os menores e mais caudais são os colículos inferiores (Fig. 18). 
Figura 18 -Peça úmida da face antero-lateral do mesencéfalo e ponte

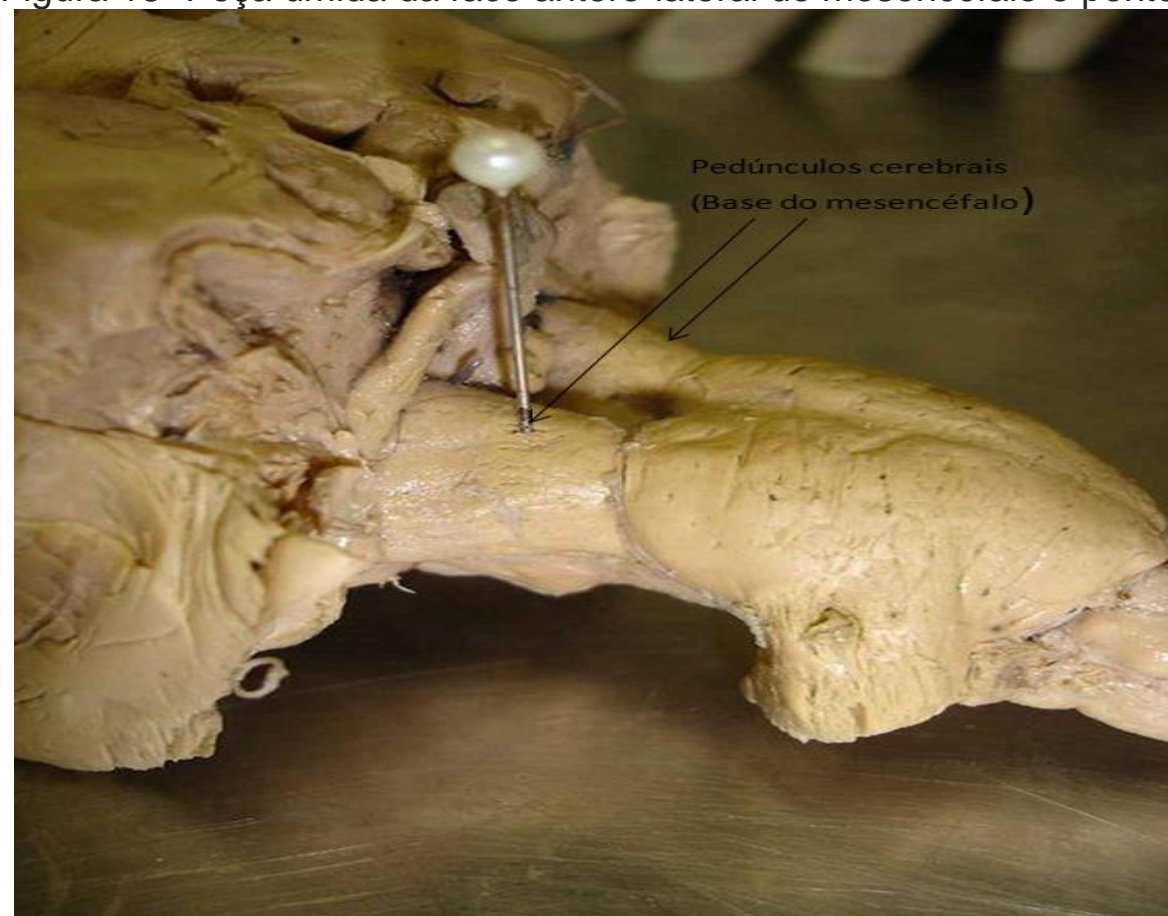

Fonte:Site Didático de Anatomia Pat., Neuropatologia e Neuroimagem (2015)

\subsection{ASPECTOS MICROSCÓPICOS DO MESENCÉFALO}

\subsubsection{Organização geral}

Em geral, são identificadas três subdivisões em secções do mesencéfalo. $O$ teto é uma mistura de substância cinzenta e branca situada posteriormente à substância cinzenta central. Ele contêm os colículos superiores e inferiores (lâmina quadrigêminal). O termo lâmina quadrigêminal foi criado por Versalius para se referir ao teto.

O tegmento, principal parte do mesencéfalo, situa-se anteriormente à substância cinzenta central e contém tratos ascendentes e descendentes, núcleos reticulares e grupos nucleares bem delimitados. A parte basilar inclui os pedúnculos cerebrais, feixes macicos de fibras corticofugais na região anterior do mesencéfalo, e a substância negra, grupo nuclear pigmentado com neuromelanina disposto entre a face posterior do pedúnculo cerebral e o tegmento. O termo base do pedúnculo é usado para se referir à parte basilar do mesencéfalo. O termo pilar do cérebro á atribuído ao feixe maciço de fibras corticofugais situado na face anterior do mesencéfalo. Às vezes o termo pedúnculos cerebral é usado erroneamente para 
identificar a porção do mesencéfalo situada anteriormente ao teto (tegmento e parte basilar).

\subsubsection{Estruturas no nível do colículo inferior}

O núcleo do colículo inferior ocupa o teto no nível do colículo inferior (Fig. 19). Esse núcleo é uma massa oval de neurônios pequenos e médios organizados em três partes 1) uma massa laminada principal de neurônios denominada núcleo central; 2 ) uma delgada camada celular posterior,o núcleo pericentral;3) um grupo de neurônios que envolvem o núcleo central látero-anteriormente,o núcleoperiférico. O núcleo central é o maior núcleo retransmitidor da via acústica.

Sons de alta frequência são representados na parte anterior e sons de baixa frequência na parte posterior do núcleo. O núcleo pericentral recebe apenas influxo monoaural contralateral e proporciona atenção auditiva direta. O núcleo periférico está relacionado principalmente a reflexos acusticomotores. O colículo inferior apresenta conexões aferentes e eferentes (AFIFI; BERGMAN, 2005).

a) Conexões aferentes: fibras que se originam das seguintes regiões:

- Lemnisco lateral. Essas fibras terminam nos colículos inferiores ipisi e contralateral. Algumas fibras do lemnisco lateral contornam o colículo inferior para chegar ao corpo geniculado medial.

- Colículo inferior contralateral.

- corpo geniculado medial ipsilateral. Essa conexão serve como mecanismo de feedback na via acústica.

- Córtex cerebral(córtex acústico primário).

- Córtex cerebelar através do véu medular superior.

b) Conexões eferentes: o colículo inferior projeta-se para as seguintes áreas

-Corpo geniculado medial através do braço do colículo inferior. Essa via está relacionada à audição.

-Colículo inferior contralateral.

- Colículo superior. Essa via estabelece reflexos para rodar a cabeça e os olhos em resposta a um som. 
-Núcleo do lemnisco lateral e outros núcleos retransmissores do sistema acústico para feedback.

- Cerebelo. O colículo inferior é um grande centro para transmissão de impulsos acústicos ao cerebelo através do véu medular superior. Consequentemente, 0 colículo inferior é um núcleo retransmissor na via acústica para o córtex cerebral e o cerebelo.

Além disso, o colículo inferior desempenha um papel na localização da origem do som (AFIFI; BERGMAN, 2005).

Figura 19- Corte histológico axial do terço inferior do mesencéfalo

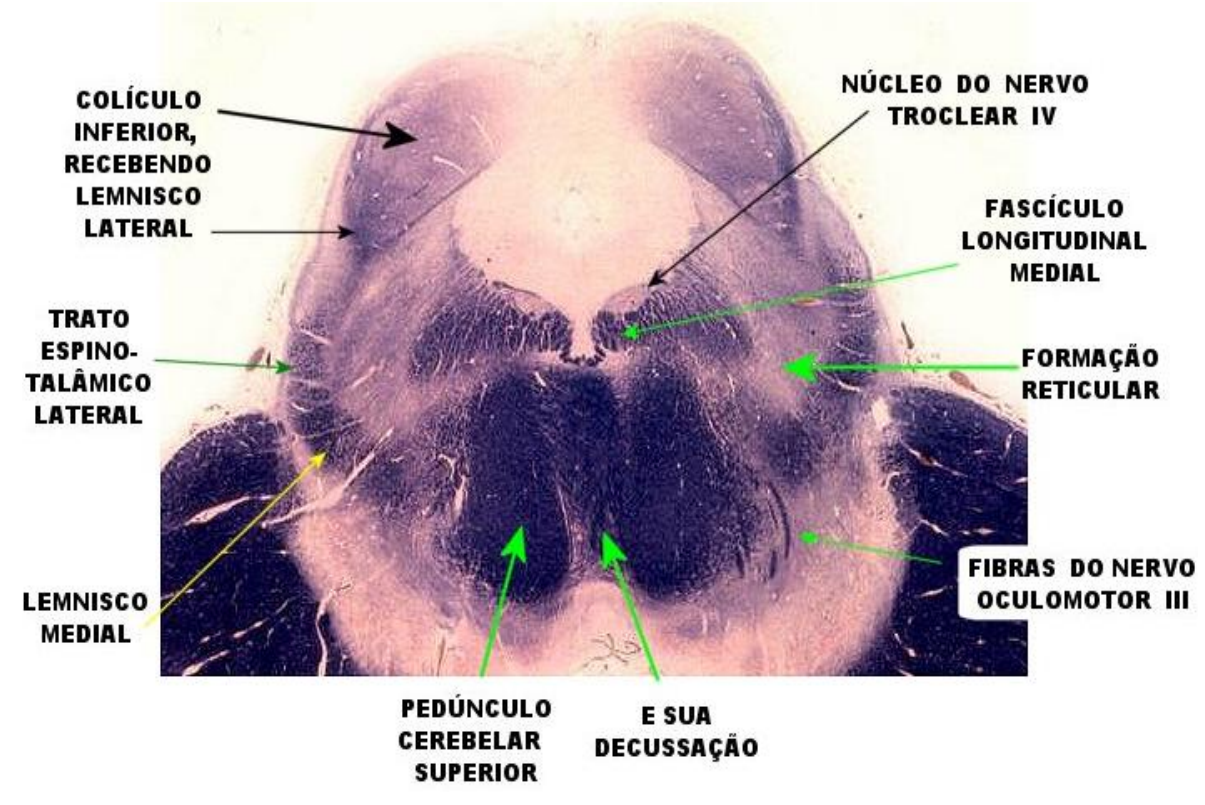

Fonte: Site Didático de Anatomia Pat., Neuropatologia e Neuroimagem (2015)

\subsubsection{Tegmento do Mesencéfalo}

No nível do colículo inferior, o tegmento do mesencéfalo contém fibras de passagem (tratos ascendentes e descendentes) e grupos nucleares.

a) Fibras de passagem

- O pedúnculo cerebelar superior é um feixe maciço de fibras que se originam nos núcleos do cerebelo. Essas fibras decussam no tegmento do mesencéfalo neste nível. Algumas continuam superiormente para terminar no núcleo rubro; outras 
formam a cápsula do núcleo rubro e continuam superiormente para terminar nos núcleos ventrais laterais do tálamo.

- O Lemnisco medial estende-se lateralmente à decussação dos pedúnculos cerebelares superiores e posteriormente à substância negra. Esse sistema de fibras, que conduz cinestesia e tato discriminativo de níveis mais inferiores, continua seu trajeto até 0 tálamo. As fibras do lemnisco medial são organizadas somototropicamente (fibras cervicais são mais mediais e fibras sacrais são mais laterais).

- O Lemnisco trigeminal é composto dos tratos trigeminotalámicos anteriores e se estende junto ao lemnisco medial até o tálamo.

-O trato espinotalámico conduz sensibilidade dolorosa e térmica da metade contralateral do corpo e se estende lateralmente ao lemnisco medial. Misturadas com as fibras espinotalámicas estão as fibras espinotectais,que se estendem ao teto do mesencéfalo. As fibras espinotalámicas são organizadas somatotropicamente (fibras cervicais são mais mediais e fibras sacrais são mais laterais).

-O lemnisco lateral contém fibras acústicas e está situado póstero - medialmente ao trato espinotalámico.

- O Fascículo longitudinal medial, via de associação, faz a conexão entre todos os núcleos motores de nervos cranianos. Importante para a realização de reflexos integrados no tronco encefálico, como aqueles que coordenam os movimentos da cabeça com os do globo ocular. O fascículo longitudinal medial mantém a posição paramediana na região posterior do tegmento.

- O trato tegmental central contém fibras que se estendem dos núcleos da base e mesencéfalo ao complexo olivar inferior. Ocupa uma posição posterior no tegmento, ântero - lateralmente ao fascículo longitudinal medial.

- O trato rubroespinhal contém fibras que se estendem do núcleo rubro à medula espinhal e complexo olivar inferior e localiza-se posteriormente à substância negra.

b) Grupos nucleares (nível dos colículos inferiores)

- O núcleo mesencefálico do nervo trigêmeo. O núcleo mesencefálico é estruturalmente homólogo ao gânglio sensitivo espinhal mas situa-se, de maneira única dentro do sistema nervoso central. Contém neurônios unipolares com axônios que conduzem impulsos proprioceptivos dos músculos da mastigação e dos ligamentos periodontais. Conforme se aproximam do núcleo, essas fibras se 
agrupam constituindo um feixe próximo ao núcleo: o trato mesencefálico do nervo trigêmeo.

- Núcleo do nervo troclear (IV) nervo craniano. O núcleo do nervo troclear situa-se na parte anterior (em forma de V) da substância cinzenta central. Os axônios desse nervo curvam-se ao redor da substância cinzenta central, cruzam o véu medular superior e emergem na face posterior do mesencéfalo. Esses axônios inervam o músculo obliquo superior do bulbo ocular. O nervo troclear é, portanto, único em dois aspectos: é o único nervo craniano que cruza antes de emergir do tronco encefálico e o único que emerge pela face posterior do tronco encefálico.

Já o Núcleo posterior da rafe, localiza-se na parte anterior da substância cinzenta central (periaquedutal) entre os núcleos dos nervos trocleares. Esse núcleo envia fibras serotoninérgicas à substância negra, estriado e neocórtex.

- O Locus ceruleus (núcleo pigmentoso) é observado na parte superior da ponte e inferior do mesencéfalo. No nível do colículo inferior está situado na margem da substância cinzenta central. Compõe-se de quatro subnúcleos: Central (o maior); anterior (extremidade rostral); ventral (caudal e ventral), também conhecido como núcleo subcerúleo; e póstero dorsal (menor). Suas células pigmentadas contém grânulos de melanina, que desaparecem em pacientes com doença de Parkinson.

Os neurônios do locus ceruleus provêm inervação noradrenérgica à maioria das regiões do sistema nervoso central. Os axônios dos neurônios do locus ceruleus são extensamente ramificados e isso acontece em praticamente todo encéfalo. Acredita-se que este núcleo atue na regulação da respiração, assim como no estágio de movimentos rápidos dos olhos (REM) durante o sono (AFIFI; BERGMAN, 2005).

\subsubsection{Parte Basilar do mesencéfalo}

No nível do colículo inferior, a parte basilar do mesencéfalo inclui os pedúnculos cerebrais e a substância negra.

- Pedúnculo cerebral

O pedúnculo cerebral é um feixe de fibras que ocupa a porção mais anterior do mesencéfalo. É contínuo com a cápsula interna superiormente e penetra inferiormente na parte basilar da ponte. Esse feixe maciço contém fibras cortifugais que se estendem do córtex cerebral a vários centros subcorticais. Os três quintos 
médios do pedúnculo cerebral são ocupados pelo trato corticoespinhal, que inferiormente é contínuo com a pirâmide. As fibras destinadas ao membro superior localizam-se medialmente, aquelas destinadas ao membro inferior estão lateralmente dispostas, e as fibras para o tronco dispõem-se entre os dois primeiros grupos. No pedúnculo cerebral, as fibras corticopontinas situam-se a cada lado das fibras corticoespinhais. As fibras corticopontinas localizadas medialmente constituem o trato frontopontino; as fibras localizadas lateralmente constituem os tratos parieto, occipto e temporopontinos.

As fibras corticopontinas originam-se em amplas áreas do córtex cerebral, estabelecem sinapses nos núcleos da ponte e adentram o hemisfério contralateral do cerebelo através do pedúnculo cerebelar médio. As fibras corticonucleares, destinadas aos núcleos de nervos cranianos, ocupam uma posição póstero-medial entre as fibras corticoespinhais. O pedúnculo cerebral em humanos possui dois grupos de tratos corticonucleares: aqueles situados na porção do pedúnculo, que descem até os neurônios da ponte responsáveis pelo olhar; e outros na porção lateral, que descem até os núcleos motores dos V,VII e XII nervos cranianos e ambíguo.

\section{- Substância negra}

A substância negra foi identificada em 1786, pelo médico francês Felix Vicq d' Azyr. Foi então considerada parte do nervo oculomotor graças a sua proximidade com as radículas deste nervo. A substância negra é uma massa pigmentada de neurônios disposta entre os pedúnculos cerebrais e o tegmento. É composta de duas áreas: uma parte compacta posterior contendo o pigmento melanina e uma parte reticular anterior contendo compostos de ferro. Os dendritos dos neurônios da parte compacta ramificam-se na parte reticular. A área lateral representa a parte mais antiga desse núcleo. A população neuronal da substância negra consiste em neurônios pigmentados e não pigmentados, lembrando que a quantidade de neurônios pigmentados corresponde ao dobro de não pigmentados.

O neurotransmissor dos neurônios pigmentados é a dopamina. Os neurônios não pigmentados são colinérgicos ou GABAérgicos. Há um padrão característico de perda neuronal na substância negra em cada doença. Na coreia de Huntington os pacientes apresentam perda de neurônios pigmentados e não pigmentados. $\mathrm{Na}$ 
doença de Parkinson idiopática ocorre perda apenas dos neurônios pigmentados (dopaminérgicos, especialmente aqueles do centro da substância negra. Na doença de Parkinson do tipo pós encefalítico, há perda uniforme de neurônios pigmentados (dopaminérgicos). No complexo de Parkinson demência, há perda uniforme de neurônios pigmentados e não pigmentados. Na atrofia multissistêmica, há perda de neurônios pigmentados nas zonas nigrais medial e lateral.

- Mesencéfalo no Nível do Colículo Superior

O núcleo do colículo superior ocupa o teto no nível do colículo superior. colículo superior e é uma massa laminada de substância cinzenta que atua nos reflexos visuais e no controle dos movimentos oculares. O aspecto laminado resulta de estratos alternados de substância branca e cinzenta. Os estratos superficiais do colículo superior contêm células alinhadas de modo ordenado com campos receptivos visuais bem definidos e aparentemente representam um mapa do espaço visual. Por outro lado os estratos profundos contêm células cuja atividade está relacionada aos alvos dos movimentos sacádicos dos olhos. Parece, portanto, que um mapa sensorial do espaço visual nos estratos superficiais é transformado, nos estratos profundos, em um mapa motor onde é representado por um vetor de uma posição ocular inicial para uma posição-alvo. Em seguida, o vetor é traduzido em sinais de comando para geradores sacádicos como a formação reticular pontina paramediana (AFIFI; BERGMAN, 2005). 
Figura.20-Corte axial histológico do mesencéfalo no nível do colículo superior

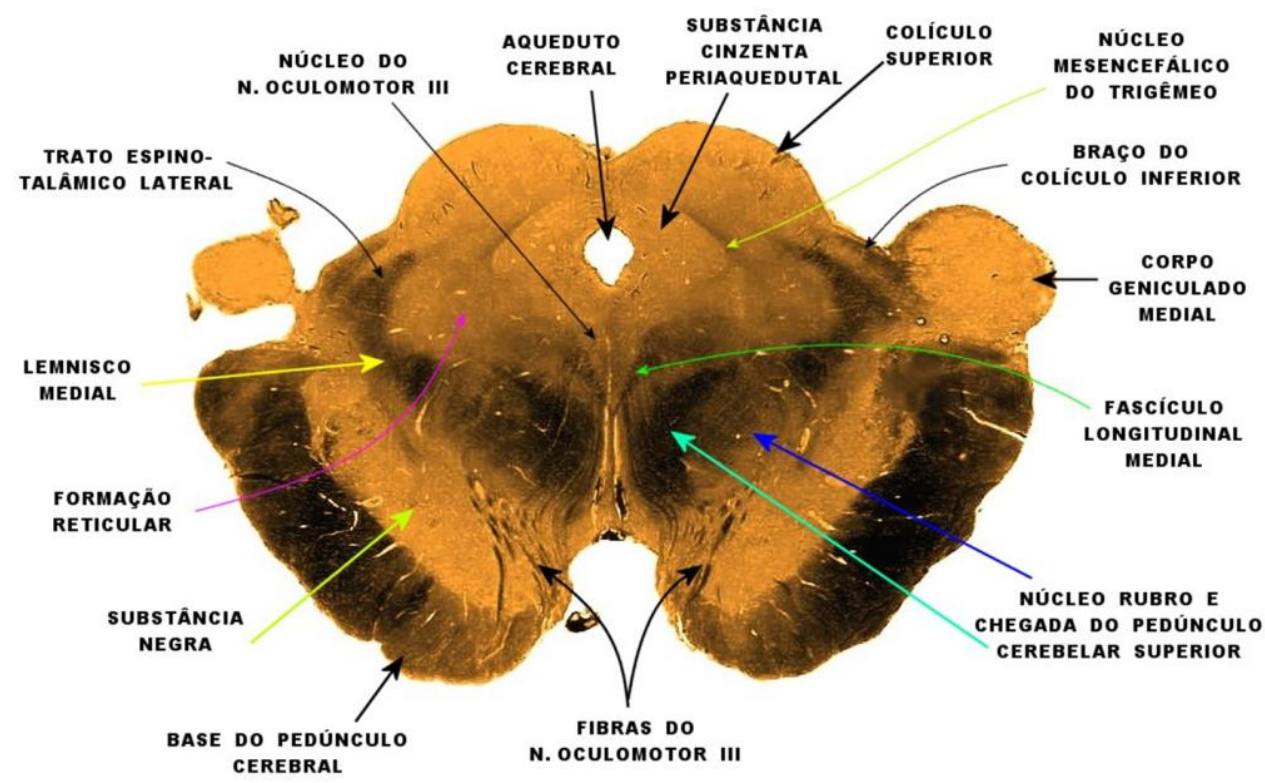

Fonte: Site Didático de Anatomia Pat., Neuropatologia e Neuroimagem (2015)

e) Área Pré -Tectal

A áreas pré-tectal situam-se rostralmente ao colículo superior na junção mesencéfalo-diencefálica. Essa área é um centro importante da via para reflexo pupilar à luz e para o olhar vertical. Ela recebe fibras das retinas e projeta fibras bilateralmente para os núcleos dos nervos oculomotores. Identificam-se vários núcleos da área pré-tectal, incluindo o núcleo do trato óptico ao longo da margem póstero-lateral da área pré-tectal junto à união com o pulvinar, e o núcleo pré-tectal olivar, mais bem observado no nível caudal da comissura posterior.

Experimentos de ablação da área pré-tectal e ou da comissura posterior sugerem fortemente que tais estruturas sejam essenciais para o olhar vertical. Isso pode explicar a paralisia do olhar vertical em pacientes com tumores da pineal que comprimem essas estruturas.

-Tegmento no nível do colículo superior

No nível do colículo superior, o tegmento do mesencéfalo contém fibras de passagem e grupos nucleares. As fibras de passagem incluem todos os tratos encontrados no nível do colículo inferior, exceto o lemnisco lateral,que termina nos neurônios do colículo inferior e não é observado no nível do colículo superior. As fibras do pedúnculo cerebelar superior, que decussam no nível do colículo inferior, 
terminam no núcleo rubro nesse nível ou formam a cápsula a do núcleo rubro durante seu trajeto até o tálamo.

\section{- Núcleo Rubro}

O núcleo rubro é assim denominado, pois em preparações a fresco sua rica vascularização lhe proporciona uma coloração rósea, é uma característica marcante do tegmento neste nível (Fig.21). É composto de uma parte superior com células pequenas (parvocelular), filogeneticamente recente, e uma parte inferior com células grandes (magnocelular), filogeneticamente mais antiga. A parte superior é bem desenvolvida em humanos. O núcleo é atravessado pelos seguintes sistemas de fibras 1) pedúnculo cerebelar superior 2) radículas do nervo oculomotor; e 3) trato habenulointerpeduncular. Entre os três sistemas, apenas o pedúnculo cerebelar superior projeta-se para o núcleo rubro; os outros dois têm apenas relações de proximidade com esse núcleo.

O núcleo rubro mantém conexões aferentes com: núcleos cerebelares, córtex cerebral e conexões eferentes com a medula espinal, cerebelo e complexo olivar inferior. O núcleo rubro é, portanto, um estação sináptica de sistemas neurais relacionados com movimentos, interconectando córtex cerebral, cerebelo e medula espinal. Lesões do núcleo rubro resultam em tremor contralateral.

- Núcleo do nervo oculomotor

O núcleo do nervo oculomotor estende-se, posteriormente, ao fascículo longitudinal medial (FLM) no nível do colículo superior. É composto de uma coluna celular motora somática lateral e uma coluna celular visceral medial.Tem aproximadamente $10 \mathrm{~mm}$ de comprimento. Esse núcleo recebe fibras das seguintes regiões: Córtex cerebral, Mesencéfalo, Ponte e bulbo, Cerebelo.

A coluna motora somática é organizada em subgrupos para cada um dos músculos do bulbo do olho inervados pelo nervo oculomotor. A partir da porção mais rostral do núcleo do nervo oculomotor até seu terço médio estão os núcleos viscerais (de Edinger-Westphal) e os subnúcleos dos retos inferiores. Os subnúcleos dos retos inferiores estendem-se rostralmente como uma península e são os únicos subnúcleos observados na parte mais rostral do núcleo. Uma lesão discreta no núcleo do nervo oculomotor em sua parte mais rostral pode resultar em paresia isolada do músculo reto inferior, com ou sem alterações pupilares. 
Os subnúcleos dos oblíquos inferiores são os que possuem localização mais lateral nos terços médio e caudal do complexo nuclear. Os subnúcleos dos retos superiores estão medialmente localizados nos terços médio e caudal do núcleo e são os únicos subnúcleos desse complexo nuclear que suprem os músculos oculares contralaterais (músculo reto superior). Todos os outros subnúcleos suprem os músculos oculares ipsilaterais correspondentes. O subnúcleo do reto superior é adjacente e caudal ao subnúcleo do reto inferior. Uma lesão levemente caudal a outra lesão que produz paralisia isolada do reto inferior pode afetar os subnúcleos dos retos inferior e superior, produzindo paresia ipsilateral do reto inferior e contralateral do reto superior.

Os subnúcleos dos retos mediais localizam-se, principalmente, na região anterior do complexo nuclear oculomotor próximos ao fascículo longitudinal medial. O subnúcleo do levantador da pálpebra superior é um núcleo central único situado no terço caudal do complexo nuclear. Seus axônios dividem-se em fascículos direto e esquerdo para inervar os dois músculos levantadores das pálpebras superiores.

\subsubsection{Substância Cinzenta Central(Periaquedutal)}

A região cinzenta central do mesencéfalo circunda o aqueduto de Sylvius e contém neurônios dispersos, vários núcleos e algumas fibras amielínicas e mielínicas delgadas. O núcleo do nervo oculomotor, os núcleos acessórios do nervo oculomotor, o núcleo do nervo troclear, assim como o núcleo mesencefálico do nervo trigêmeo, localizam-se no limite dessa região. O fascículo longitudinal posterior (fascículo de Schütz) é um sistema de fibras periventriculares ascendentes e descendentes, que se estende pela substância cinzenta central. Origina-se parcialmente do hipotálamo e contém fibras autônomas. Em geral, conecta o hipotálamo com a substância cinzenta central do mesencéfalo e com os núcleos autônomos da ponte e do bulbo.

O neuropeptídio encefalina foi identificado na substância cinzenta central. A estimulação de determinados sítios no interior da substância cinzenta central libera encefalina, que age nos neurônios serotoninérgicos do bulbo que por sua vez projetam-se para os axônios aferentes primários (relacionados a condução da dor) do corno posterior da medula espinal para produzir analgesia. A analgesia produzida por estímulos é obtida por estimulação das regiões ântero-laterais da substância 
cinzenta central. Por outro lado,a estimulação das regiões superior e lateral da substância cinzenta central facilita a sensibilidade dolorosa.

Além de seu papel em mecanismos analgésicos centrais, a substância cinzenta central tem implicações na vocalização, controle do comportamento reprodutivo, modulação dos centos respiratórios bulbares comportamento agressivo e olhar vertical. Verificou-se que a substância cinzenta periaquedutal, junto com estratos profundos do colículo superior, está envolvida em diferentes partes de situações aversivas. Os comportamentos de fuga e defensivo são provocados por estimulação destas áreas. A substância cinzenta periaquedutal recebe informação sobre o preenchimento da bexiga urinária e, portanto,está envolvida no processo central da micção. Através de conexões com o hipotálamo e parte superior do bulbo a substância cinzenta periaquedutal foi implicada no processo de ereção do pênis.

Os influxos para essa região originam-se do hipotálamo, amígdalas, formação reticular do tronco encefálico, locus ceruleus e medula espinal. Verificou-se imunorreatividade a diversos peptídeos nos neurônios periaquedutais: esses neuropeptídios incluem a encefalina, substância $\mathrm{P}$, colecistocinina, neurotensina, serotonina, dinorfina e somatostatina.

\subsubsection{Formação Reticular Mesencefálica}

O termo formação reticular refere-se a um aglomerado de neurônios que se estendem da região caudal do bulbo à região rostral do mesencéfalo e são contínuos com a zona incerta do subtálamo e com os núcleos medianos, intralaminares e reticular do tálamo. Embora as antigas descrições da formação reticular descrevessem um emaranhado de corpos neuronais e fibras nervosas pouco organizadas, atualmente se sabe que a formação reticular está organizada em grupos nucleares definidos com conexões aferentes e eferentes conhecidas. $A$ formação reticular como um todo compreende um sistema neural com múltiplos influxos e com um sistema multissináptico de condução de impulsos.

A formação reticular mesencefálica é uma continuação dos núcleos reticulares da ponte e se funde rostralmente com a zona incerta. O principal efluxo da formação reticular mesencefálica sobe ao diencéfalo e córtex cerebral e está envolvido no sono e na vigília (AFIFI; BERGMAN, 2005). 
Figura 21-Corte axial histológico da transição mesencéfalo-diencéfalo

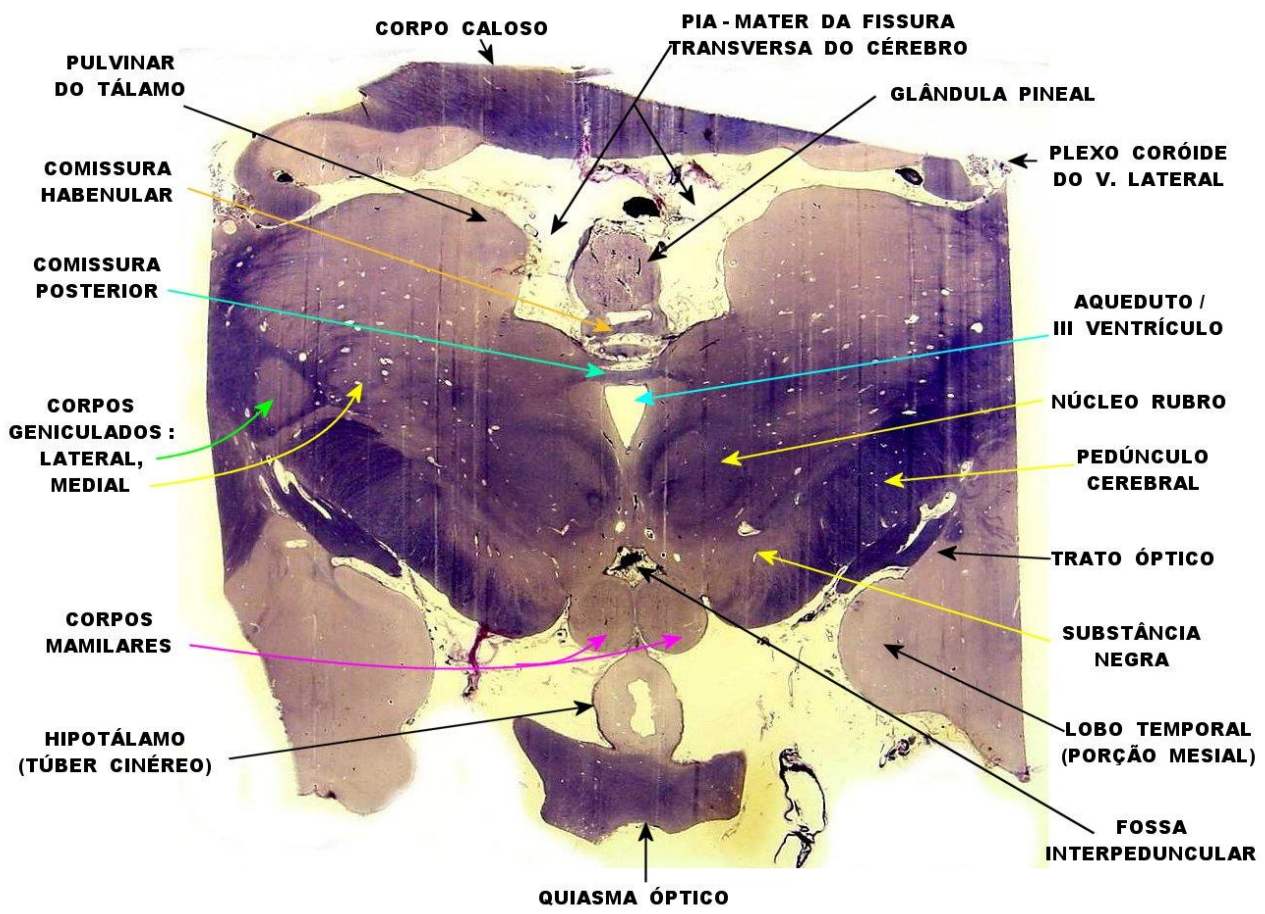

Fonte: Site Didático de Anatomia Pat., Neuropatologia e Neuroimagem (2015).

\subsection{SUPRIMENTO SANGUÍNEO DO MESENCÉFALO}

Comparada ao suprimento vascular da ponte, a irrigação do mesencéfalo é complexa. O mesencéfalo recebe suprimento sanguíneo da artéria basilar, através de ramos para medianos, assim como ramos das artérias cerebelar superior e cerebral posterior.

a) Nível do colículo inferior

No nível do colículo inferior, os ramos paramedianos irrigam a região medial do mesencéfalo, incluindo o FLM, os núcleos reticulares paramedianos e 0 pedúnculo cerebelar superior. A artéria cerebelar superior irriga a região lateral do mesencéfalo, incluindo o colículo inferior, as radículas do nervo troclear, os lemniscos espinal e medial e a parte lateral do pedúnculo cerebral.

b) Nível do colículo superior

No nível do colículo superior, o mesencéfalo é dividido em três zonas de suprimento sanguíneo. A zona medial, que inclui o complexo nuclear do terceiro nervo craniano, recebe sangue da extremidade da artéria basilar. O teto e irrigado 
pela artéria cerebelar superior. O restante do mesencéfalo é irrigado pela artéria cerebral posterior. Essa zona inclui os lemniscos espinal e medial, a substância negra, o pedúnculo cerebral, o núcleo rubro e as radículas do terceiro nervo craniano.

c) Nível pré-tetal

No nível da porção superior do mesencéfalo (pré-tetal), a zona medial, incluindo a parte medial do núcleo rubro, e as radículas do nervo oculomotor recebem sangue dos ramos paramedianos da artéria basilar. O restante do mesencéfalo recebe sangue da artéria cerebral posterior.

\subsection{CORRELATOS CLÍNICOS DO MESENCÉFALO}

\subsubsection{Síndromes Vasculares Mesencefálicas}

Os infartos mesencefálicos ainda não foram amplamente estudados. Há apenas o registro de casos únicos de infartos mesencefálicos isolados, bem descritos clinicamente e por exame de imagem de Ressonância magnética.

A região mais afetada á porção média do mesencéfalo, e o território envolvido com maior frequência é o paramediano, seguido pelo território da artéria cerebral posterior e o território intermédio entre os dois. O envolvimento do território da artéria cerebelar superior é raro.

Pacientes com infartos na porção média do mesencéfalo apresentam um quadro clínico circunscrito relacionado ao comprometimento do terceiro nervo craniano ou de seu núcleo. Os infartos paramedianos estão associados à síndrome nuclear do nervo oculomotor, enquanto infartos mais laterais estão associados ao comprometimento fascicular puro do terceiro nervo ou com hemiparesia (síndrome de Weber) ou hemiataxia (síndrome de Claude) contralaterais.

Pacientes com infartos mesencefálicos rostrais ou caudais apresentam quadro neurológico menos localizado, exceto pela deficiência do olhar vertical em pacientes com infartos mesencefálicos rostrais mais posteriores. A paralisia ipsilateral do nervo troclear, a síndrome de Horner e a ataxia contralateral apontam para o território da artéria cerebelar superior. 


\subsubsection{Síndrome de Weber}

Na síndrome de Weber, o paciente apresenta sinais de paralisia ipsilateral do nervo oculomotor e paralisia contralateral do tipo neurônio motor superior, que inclui a região inferior da base. A lesão vascular, geralmente um infarto, afeta as radículas do nervo aculomotor e o pedúnculo cerebral adjacente (Fig.22).

Figura 22 - A) axial Flair e B) Axial difusão. Área de infarto no mesencéfalo medialmente acometendo a topografia das radículas do nervo oculomotor e o pedúnculo cerebral adjacente à esquerda

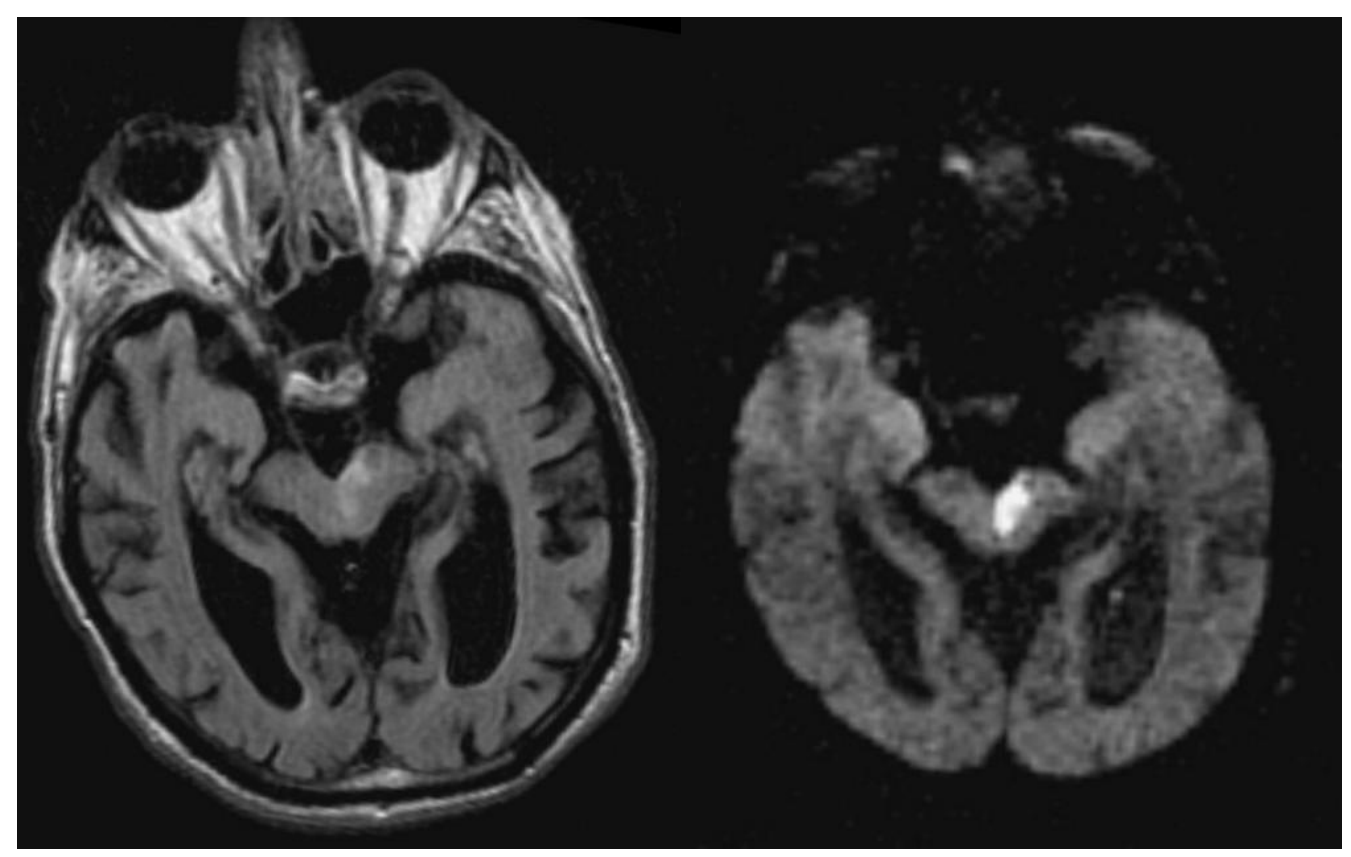

Fonte: Ayuszh e Frank et al. (2015-2016)

\subsubsection{Síndrome de Benedikt}

$\mathrm{Na}$ síndrome de Benedikt, o paciente apresenta sinais de paralisia ipsilateral do nervo oculomotor e tremor contralateral. A lesão vascular afeta as radículas do nervo oculomotor no tegmento do mesencéfalo e o núcleo rubro adjacente(Fig.23). Alguns pesquisadores descreveram hemianestesia contralateral, atribuida ao comprometimento do lemnisco medial e do trato espinotalâmico. O tremor verificado nessa síndrome foi denominado tremor rubral, devido à lesão do núcleo rubro ou do pedúnculo cerebelar supérior. 
Figura 23- A)axial T2 B) Axial GRE área hemorrágica pós traumática envolvendo o mesencéfalo lateralmente a direita

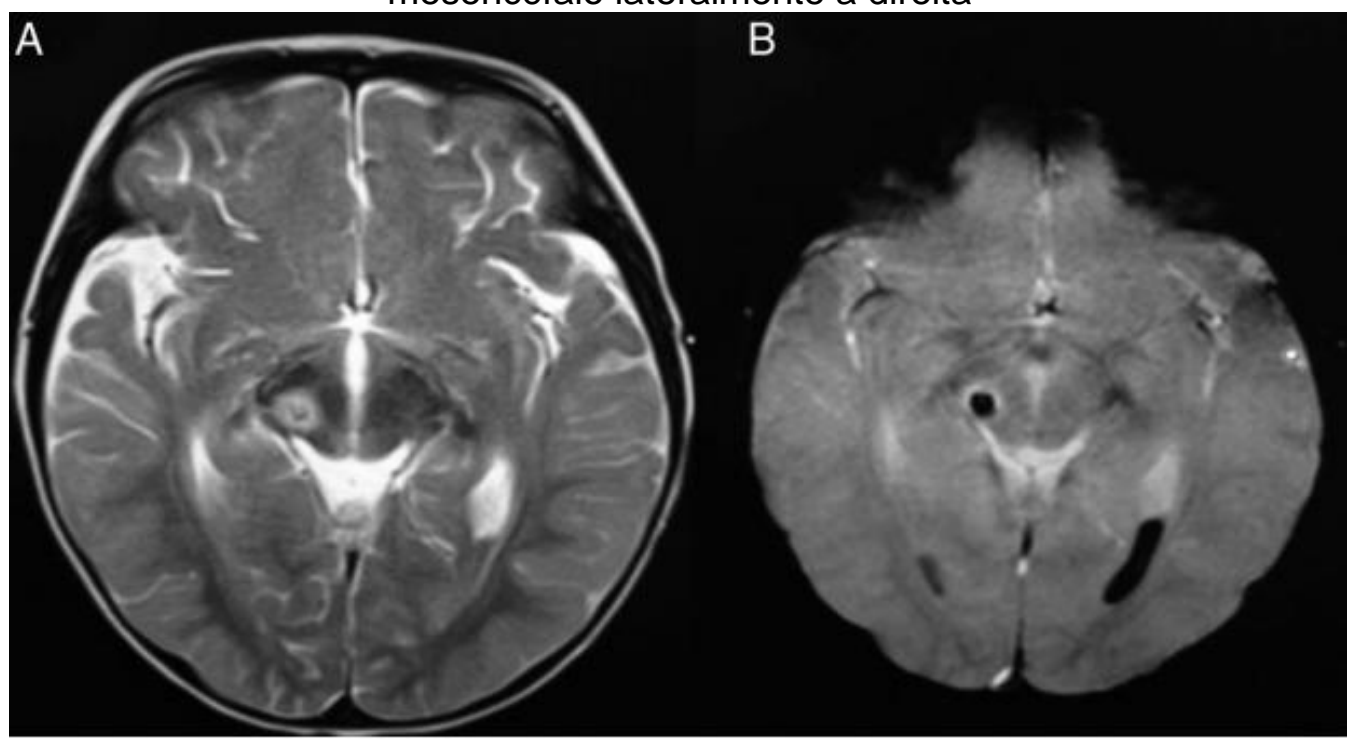

Fonte: Goel; Gaillard et al. (2015-2016).

\subsubsection{Síndrome de Claude}

Síndrome descrita, inicialmente, em 1912 pelo psiquiatra e neurologista francês Henry Claude apresentava infarto mesencefálico que envolvia a metade medial do núcleo rubro, as fibras decussantes adjacentes do pedúnculo cerebelar superior e os fascículos do nervo oculomotor (Fig.24). Os pacientes apresentavam paralisia ipsilateral do nervo oculomotor e tremor e ataxia contralaterais. O músculo mais envolvido é o reto medial seguido pelo levantador da pálpebra superior, reto superior,obliquo inferior e reto inferior. A pupila é preservado na maioria dos pacientes. 
Figura 24 - A) Axial T2 , B) Axial difusão C) Axial T2 evidenciando área de infarto na metade medial do núcleo rubro direito
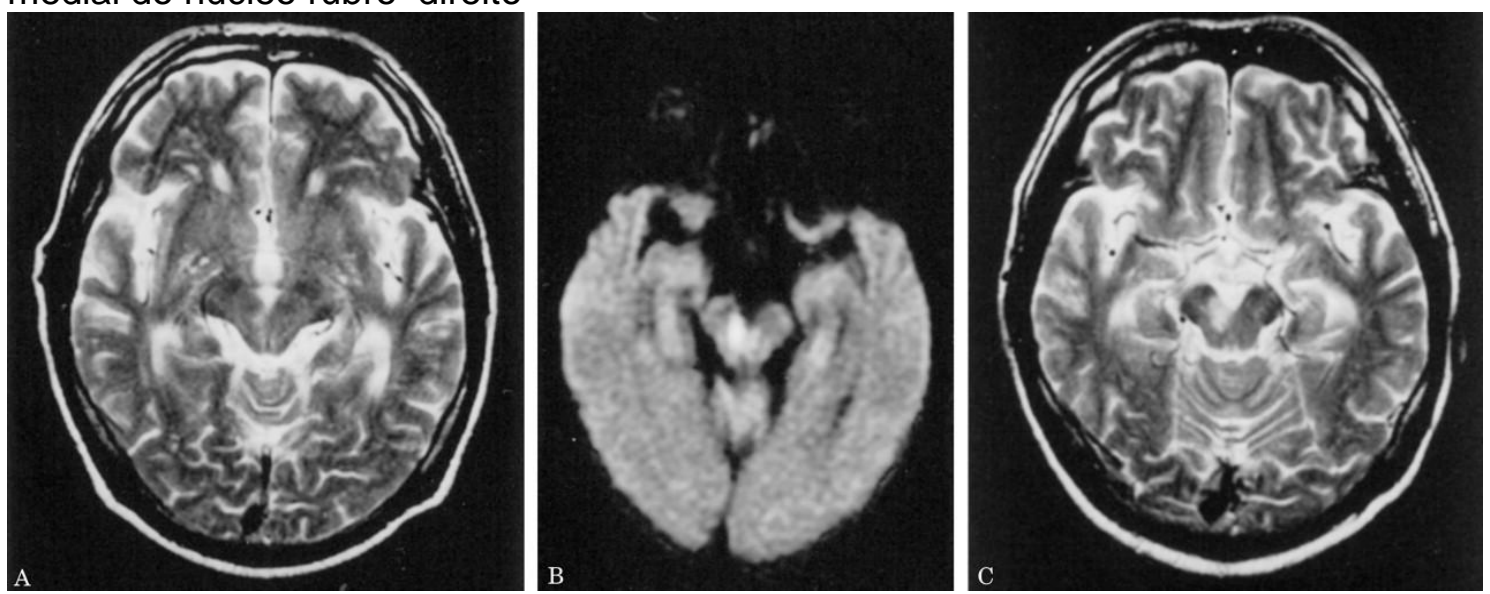

Fonte: Dr. Kiyoyuki Yanaka, Department of Neurosurgery, Institute of Clinical medicine, University of Tsukuba,Tsukuba, Ibaraki .305-8575, Japan.

\subsubsection{Síndrome plus- minus palpebral}

Esta síndrome descrita em 1992 por Gaymard et al consiste em ptose unilateral e retração palpebral contralateral decorrente de uma lesão na porção rostral do mesencéfalo, envolvendo o núcleo da comissura posterior e os fascículos do nervo oculomotor destinados ao músculo levantador ao músculo levantador da pálpebra superior quando emergem do subnúcleo caudal central (Fig.25). A ptose ipsilateral é explicada pela interrupção de fascículos do nervo oculomotor para o leventador da pálpebra superior. A retração palpebral é explicada pela superativação do levantador do pálpebra superior contralateral decorrente da perda de vias inibitórias para retração palpebral a partir do núcleo da comissura posterior para o subnúcleo caudal central. 
Figura 25- A) Axial T2 B) Axial difusão. Área de infarto medialmente no mesencéfalo
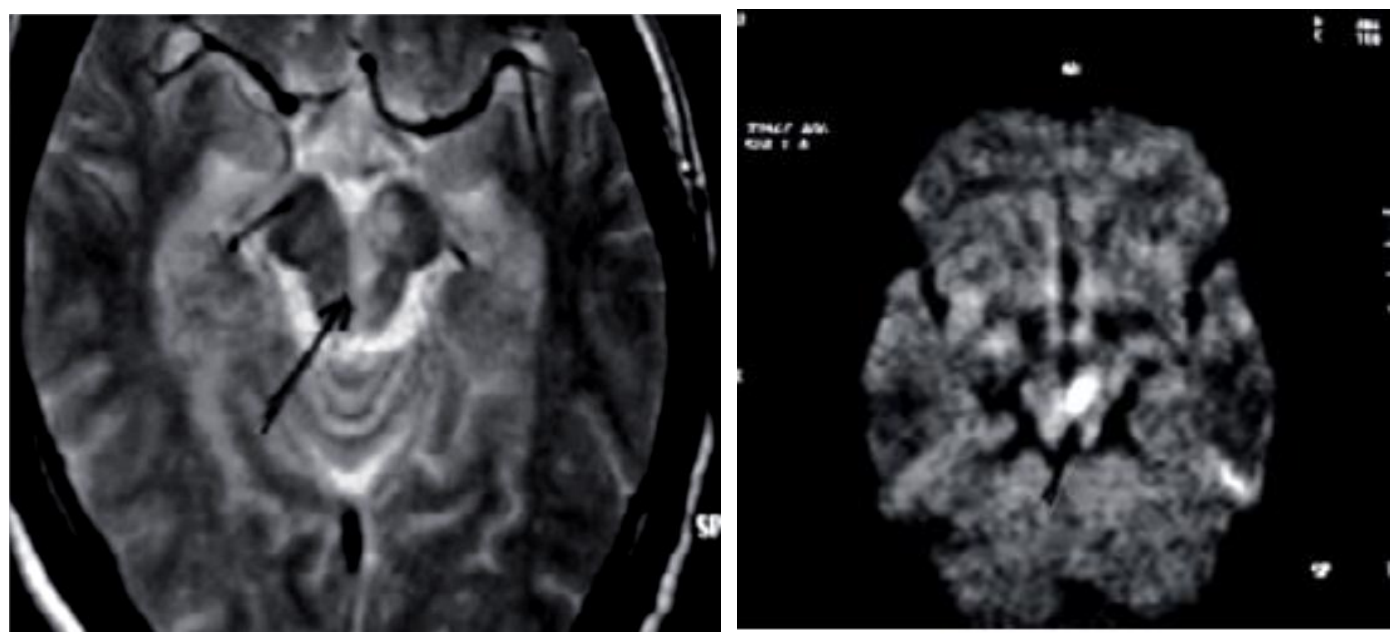

Fonte: kotwal, shenoy, joshi, apaklujkar, na nadkarni, shetty benny ,n butala, madhura patwardhan. neurology; grant medical college and sir group of hospitals, Mumbai, India.

\subsubsection{Síndrome de Parinaud}

A síndrome de Parinaud é também conhecida como síndrome do aqueduto de sylvius, ou síndrome mesencefálica dorsal. A lesão está situada na área pré-tetal (Fig.26). Os pacientes com esta síndrome apresentam paralisia do olhar para cima,alterações pupilares, retração palpebral e nistagmo de retração-convergência ao olhar para cima. Essa síndrome foi descrita em 1883 por Parinaud, que especulou vagamente sobre o local da lesão. A localizalção definitiva da lesão na área pré-tetal resultou de observações experimentais e em humanos feitas entre 1969 e 1974 por Bener, que criou o termo pré-tetal. 
Figura 26- A) axial e B) coronal T1 com contraste evidenciando germinoma da pineal comprimindo a lámina quadrigêmina
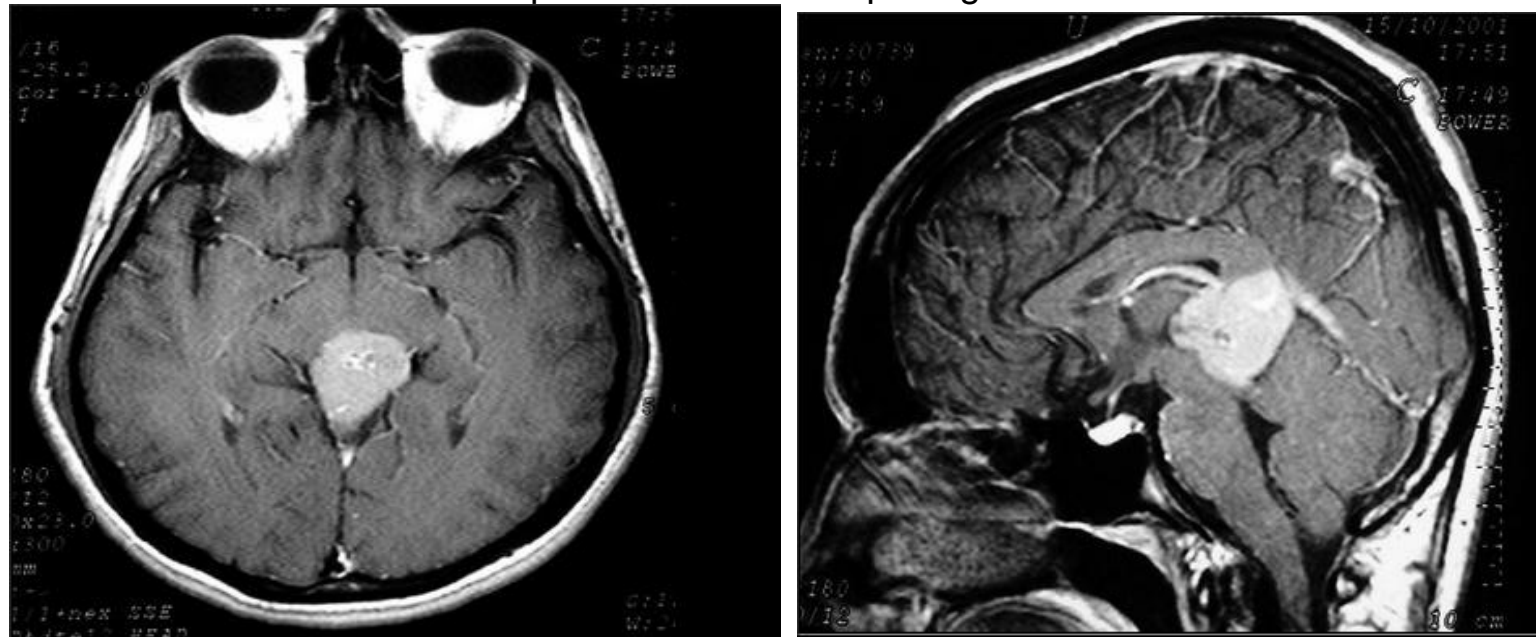

Fonte: Site Didático de Anatomia Pat., Neuropatologia e Neuroimagem (2015)

\subsubsection{Síndrome da alucinose peduncular}

Figura - 27-IRM axial T2,Lesão em pedúnculo cerebral esquerdo

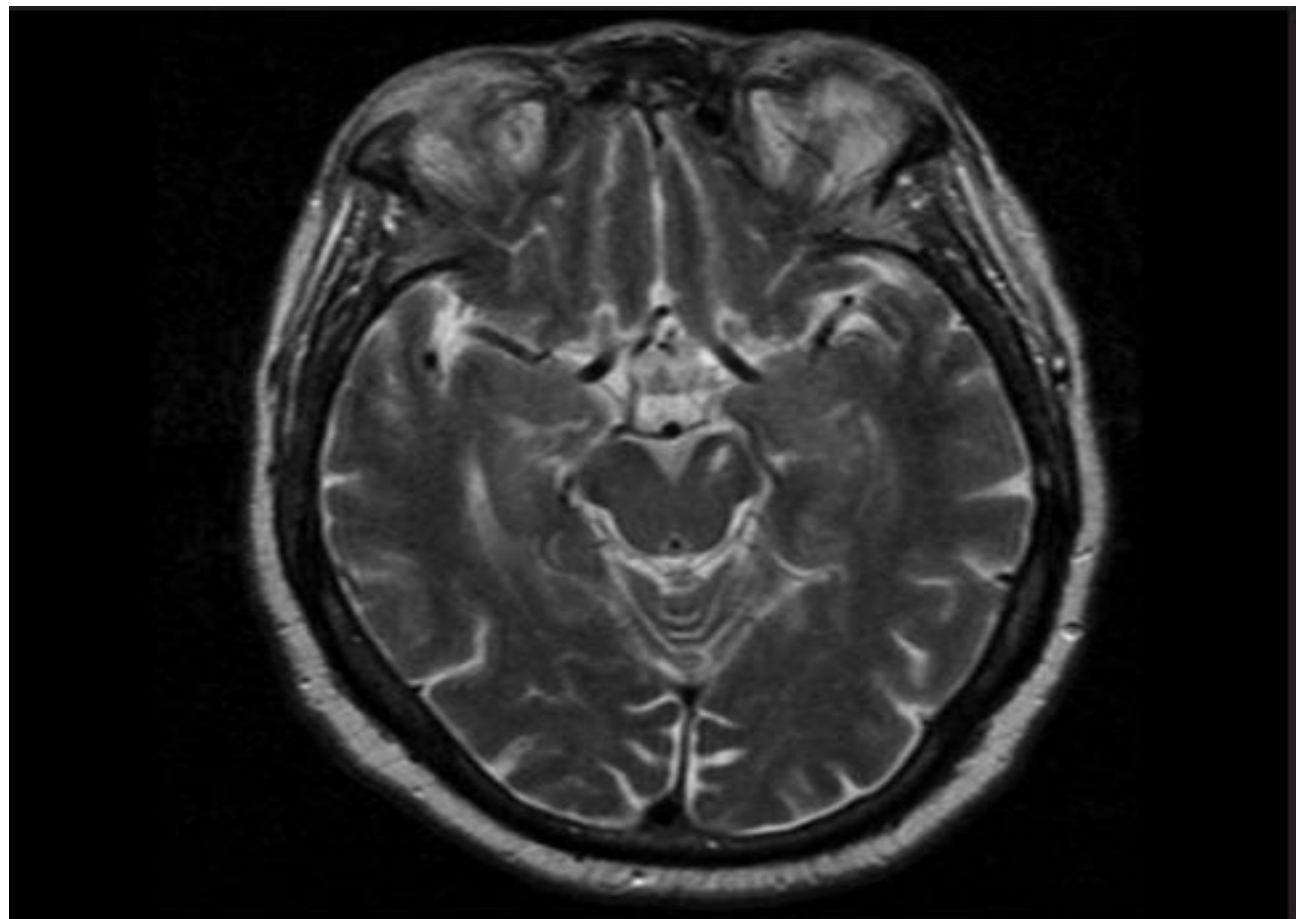

Fonte: Talih (2013) 
A síndrome da alucinose peduncular é caracterizada por alucinações não ameaçadoras, frequentemente não estereotípicas, vívidas e coloridas, que ocorrem geralmente em pacientes sonolentos com supostas lesões tegmentares e do pedúnculo cerebral. Os sintomas provavelmente se originam de lesões talámicas ou occipitotemporais em vez de lesões mesencefálicas. Essa síndrome foi descrita inicialmente em 1922, pelo neurologista francês Jean Jacques Lhermitte, em uma mulher de 75 anos de idade com infarto mesencefálico, cujas as alucinações consistiam em animais e pessoas que compartilhavam o quarto com ela. 
Materials e Métodos 


\subsection{CARACTERIZAÇÃO DA PESQUISA}

Trata-se de uma pesquisa observacional com imagens de ressonância magnética de encéfalos de cadáveres; quanto aos objetivos caracteriza-se como exploratório e descritivo uma vez que buscou-se estudar por meio de imagens ressonância magnética as estruturas microscópicas do tronco encefálico, e ao mesmo tempo tronco encefálico com cortes de ressonância magnética e cortes histológicos correlacionados, resultando na produção de uma altas de microscopia.

\subsection{PROCEDIMENTOS PARA COLETA DE DADOS}

A realização das imagens de Ressonância Magnética (RM) dos encéfalos de cadáveres foi possível mediante a autorização prévia Departamento de Patologia da FMRP-USP, que por sua vez autorizou a pesquisa "Validação da quantificação de íons paramagnéticos no cérebro por imagem de Ressonância Magnética", de modo que obtivemos o consentimento do pesquisador responsável Jeam Haroldo Oliveira Barbosa para realização da nossa técnica em três encéfalos, após a utilização dos mesmos pelo pesquisador responsável. O protocolo experimental da referida pesquisa foi aprovado pelo Comitê de Ética do Hospital das Clínicas da FMRP- USP, com o número do parecer 808.795 de 23/01/2014, tendo o consentimento do responsável pelo setor de neurorradiologia da FMRP-USP.

Inicialmente, os encéfalos foram submersos em recipiente contendo água e então lacrados de forma que o ar ambiente não entrasse no recipiente, conforme Figura abaixo: 
Figura 28-Recipiente lacrado com encéfalo para exame de imagem

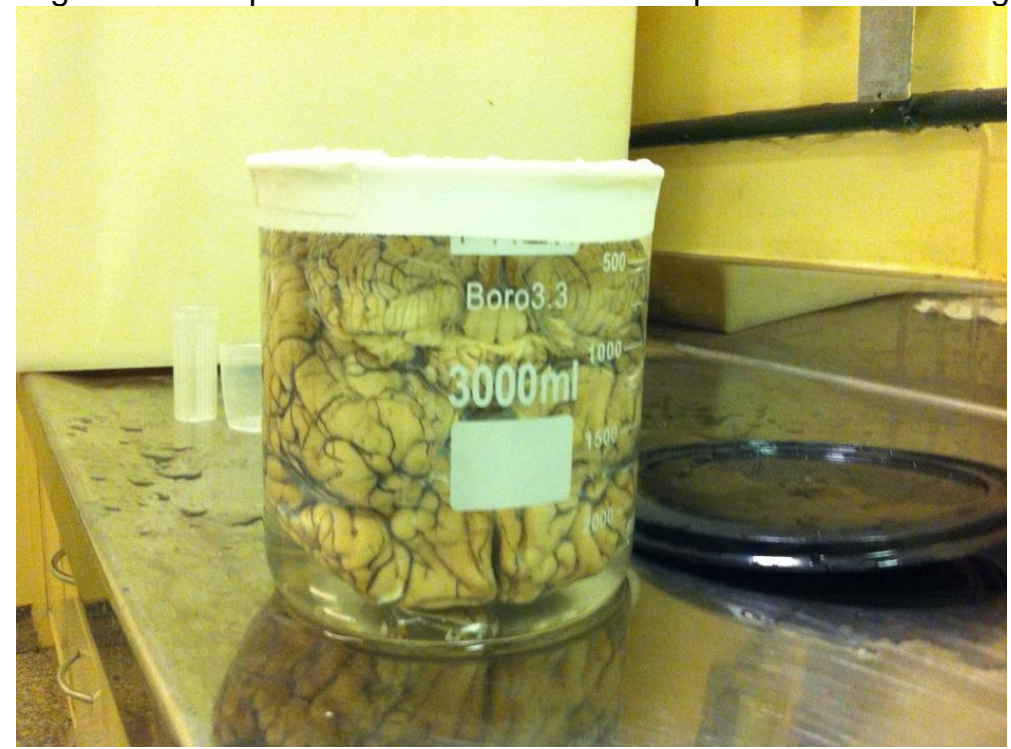

Fonte: imagens do pesquisador (2014)

As imagens de RM foram adquiridas em sequência gradiente echo (FFE) 2D em equipamento de campo 3T (PHILIPS ACHIEVA) com bobina de 8 canais de encéfalo. Foi utilizado $\mathrm{TE}=9,0 \mathrm{~ms}$, $\mathrm{TR}=1000 \mathrm{~ms}$ e o ângulo de flip $90^{\circ}$; número de médias igual 10 e BW por pixel igual a $72 \mathrm{~Hz} /$ pixel. O Fator EPI utilizado foi igual a

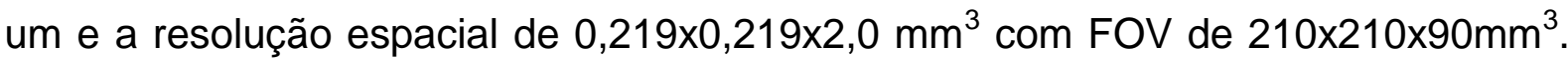
O tempo total de aquisição foi de 3 horas e 01 minuto e 96 segundos.

As imagens histológicas utilizadas no presente estudo são do banco de dados do departamento de patologia da UNICAMP, as quais foram preparadas com as seguintes técnicas: O material incluído em celoidina foi submetido a cortes de 30 $\mathrm{mm}$ de espessura, obtidos em micrótomo de deslizamento e corados pela técnica de Loyez para mielina. O material incluído em parafina foi corado pela técnica de Klüver-Barrera (luxol fast blue / cresil violeta), também para coloração da mielina. Os preparados foram fotografados diretamente em um negatoscópio com uma câmera digital Sony DSC-70, em resoluções de 640 × 480 ou 1280 × 960 pixels. Em alguns casos, slides (diapositivos) foram escaneados com resolução 600 ou 1200 dpi, em um scanner HP Scanjet 6300 C.

Estas páginas foram preparadas usando um monitor com resolução 800 x 600 pixels. Em monitores com maior resolução as imagens aparecem menores.

As imagens do banco de dados da UNICAMP estão disponíveis em boa fé, de forma aberta e gratuita, sem visar fins lucrativos ou vantagens de qualquer espécie. Destinam-se ao benefício de todos interessados em Neuroanatomia, para 
finalidades de estudo, ensino e pesquisa das dificuldades e belezas do sistema nervoso central humano. Lembramos que os direitos sobre as mesmas pertencem aos autores e estão reservados por registro público, sendo vedada a reprodução em bloco para fins comerciais. Porém, os autores concordam com a utilização das mesmas em pesquisas cientificas. 
Resultados e Discussão 


\section{APRESENTAÇÃO DOS RESULTADOS E DISCUSSÃO}

É importante ressaltar que não nos preocupamos com a possibilidade dos artefatos se movimentarem, pois as peças ficaram estáticas, mesmo com efeito do aquecimento de tecidos. Usamos uma técnica de imageamento de pequenos animais disponível no aparelho de nossa instituição focada exclusivamente no tronco encefálico.

Ao observamos as imagens obtivemos um bom resultado com a fidedignidade e clareza das imagens, como pode ser constatado nas figuras abaixo. Conseguimos, desta forma, com baixo custo e aparelho comercial de escaneamento de RM obter imagens submilimétricas do tronco encefálico, só vistas antes em imagens histológicas ou com aparelhos de RM de campos de 7 ou 9 teslas não disponíveis no Brasil. A obtenção destas imagens com RM e 3 teslas é inédita no país e não sendo encontrada na literatura mundial.

\subsection{CORRELAÇÃO DE IMAGENS HISTOLÓGICAS versus IMAGENS DE RM}

Nestas imagens podemos observar perfeitamente o trato espinal do nervo trigêmeo, o trato espino-talámico lateral, a formação reticular, as pirâmides, o lemnisco medial, as fibras arqueadas internas, os núcleos grácil e cuneiforme com seus fascículos e o canal central da medula. Todas as estruturas que foram visualizadas no corte histológico foram visualizadas na imagem de RM. 
Figura 29- Imagens de correlação entre IRM e corte histológico do bulbo no nível das pirâmides

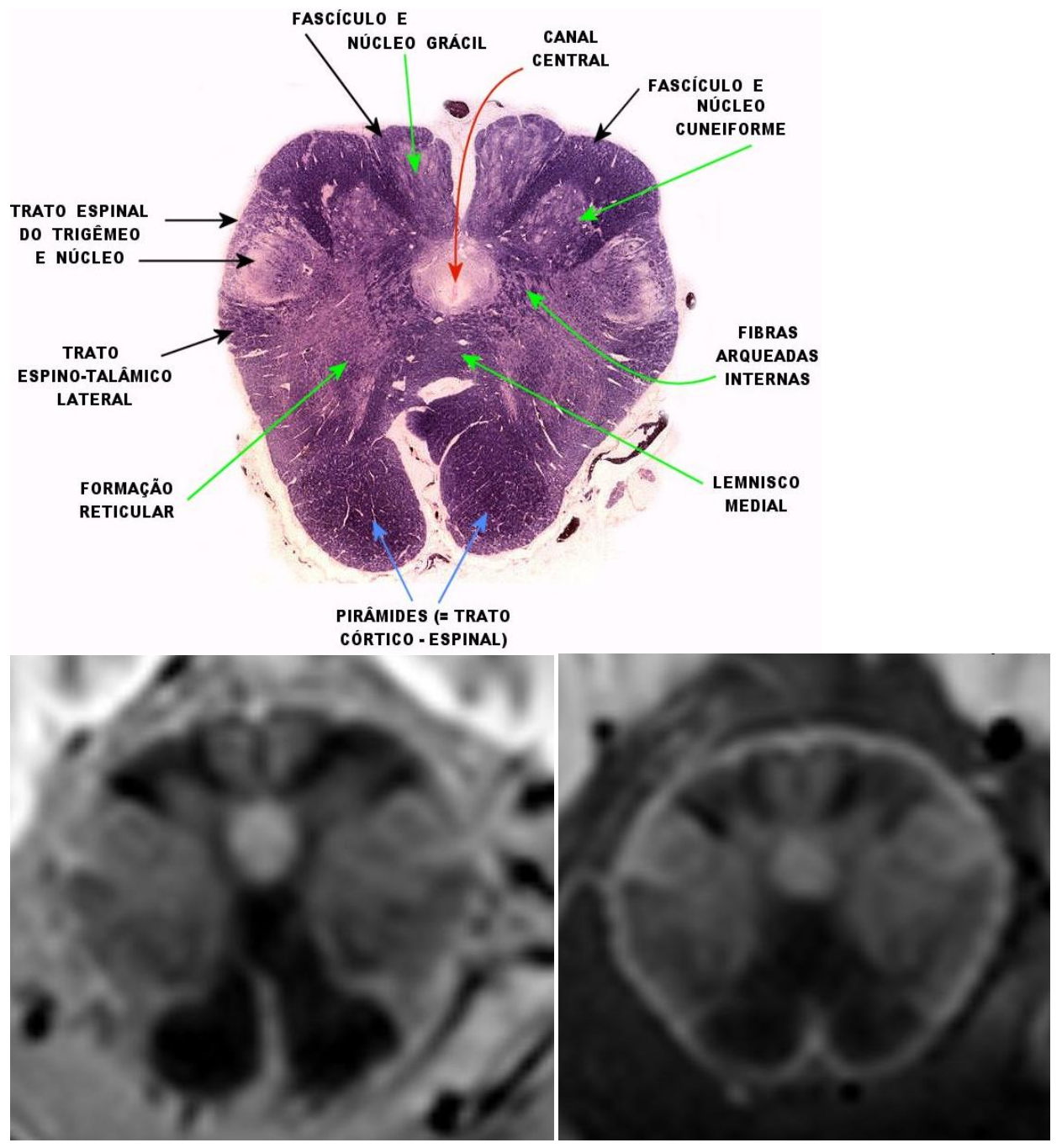

Nestas imagens podemos observar perfeitamente o trato espinal do nervo trigêmeo, o trato espino-talámico lateral, a formação reticular, as pirâmides, o lemnisco medial, as fibras arqueadas internas, os núcleos grácil e cuneiforme com seus fascículos e o canal central da medula. Todas as estruturas que foram visualizadas no corte histológico foram visualizadas na imagem de RM. 
Figura 30- Imagens de correlação entre IRM e corte histológico bulbo no nível dos núcleos olivares inferiores
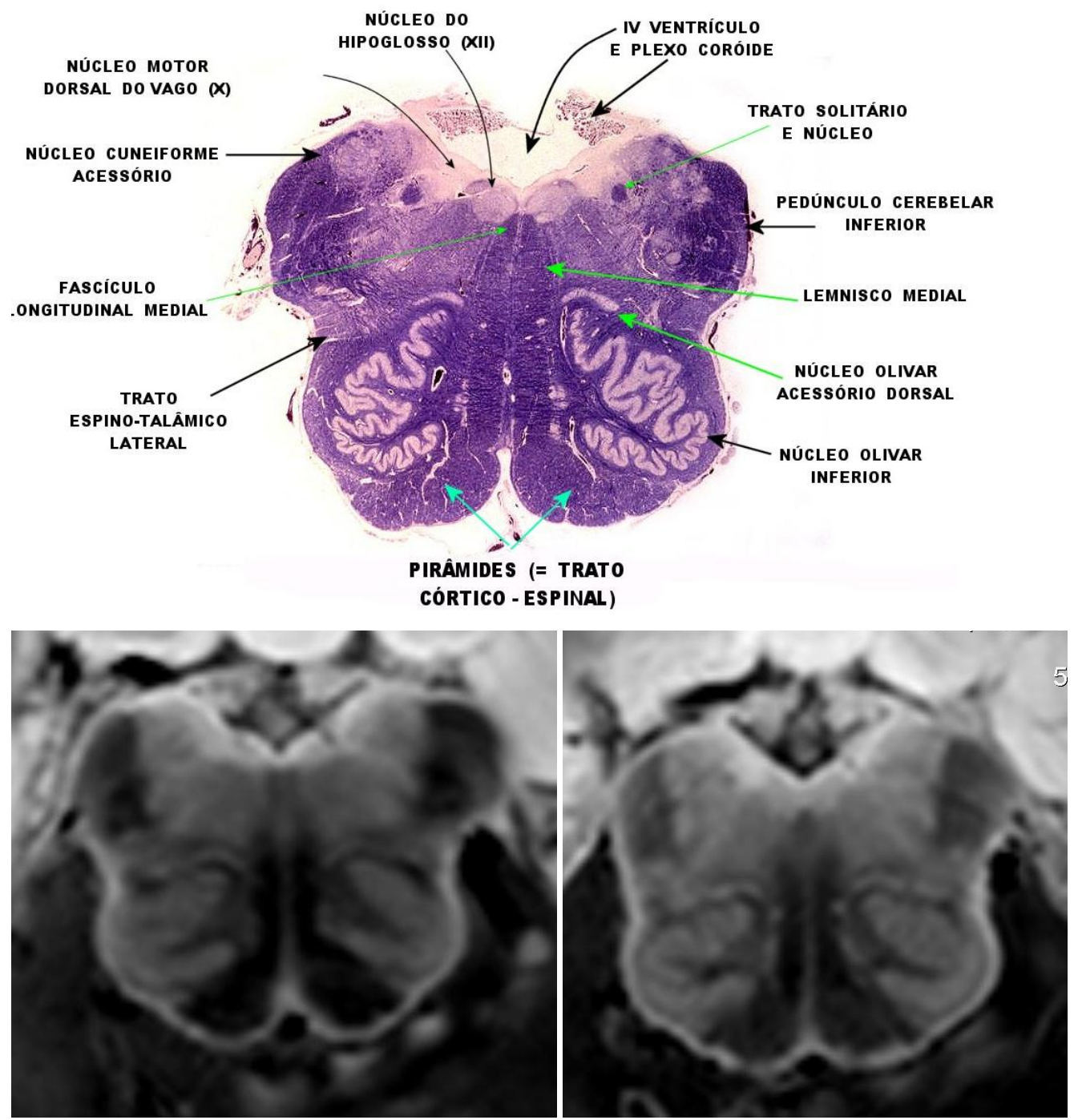

Nestas imagens podemos observar o núcleo do hipoglosso, núcleo motor dorsal do vago, o núcleo cuneiforme acessório, o fascículo longitudinal medial, o trato espino-talámico lateral, as pirâmides, o núcleo olivar inferior, o núcleo olivar acessório dorsal, o lemnisco medial, pedúnculo cerebelar inferior, o trato e núcleo solitário e o IV ventrículo e plexo coróide. Todas as estruturas que foram visualizadas no corte histológico foram visualizadas na imagem de RM. 
Figura 31- Imagens de correlação entre IRM e corte histológico no nível da transição bulbo pontina

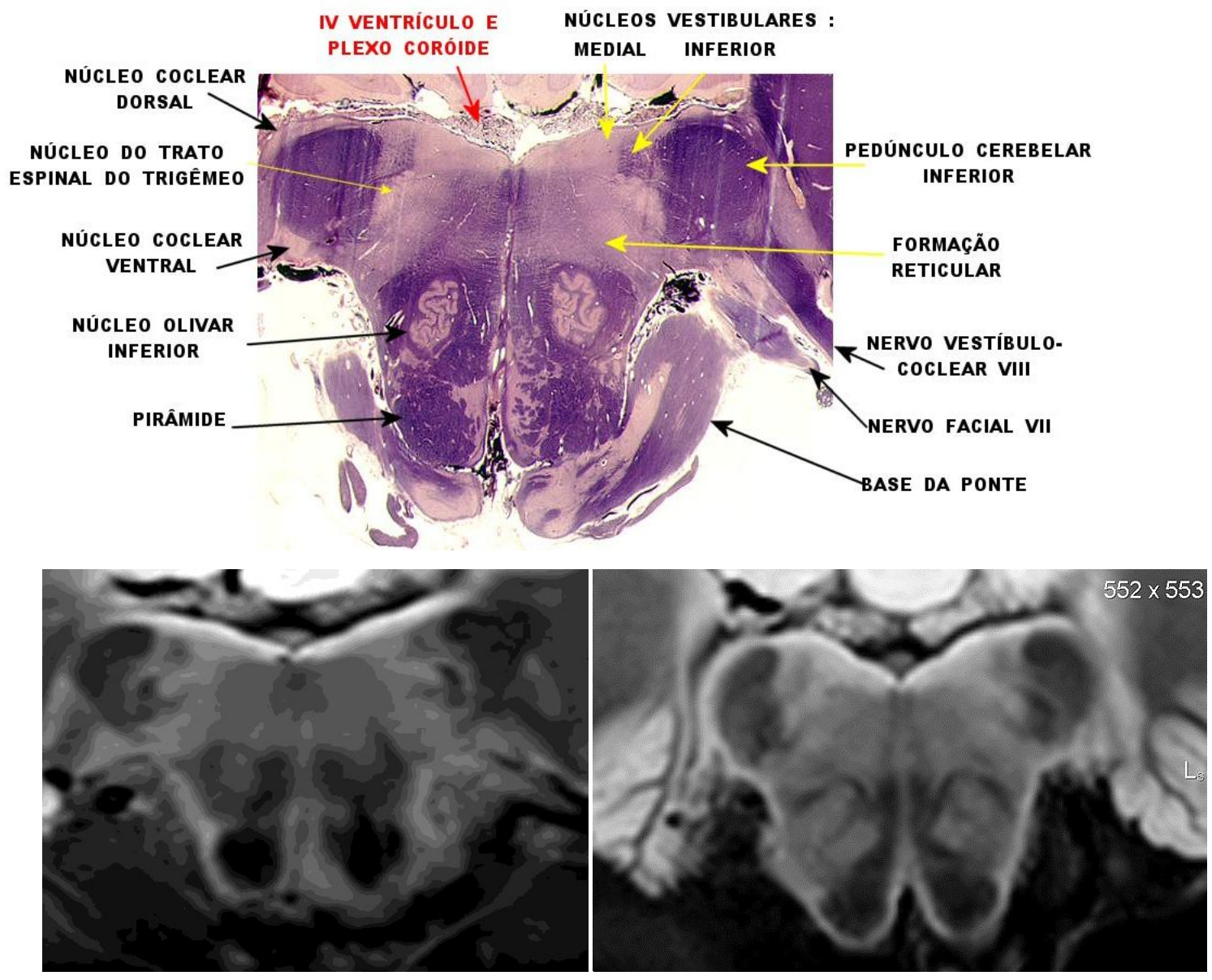

Nestas imagens podemos observar os núcleos coclear dorsal,do trato espinal do trigêmeo,coclear ventral,olivar inferior, as pirâmides a base da ponte, os nervos vestíbulo coclear e facial, a formação reticular, o pedúnculo cerebelar inferior e os núcleos vestibulares. Todas as estruturas que foram visualizadas no corte histológico foram visualizadas na imagem de RM. 
Figura 32 - Imagens de correlação entre IRM e corte histológico da Ponte

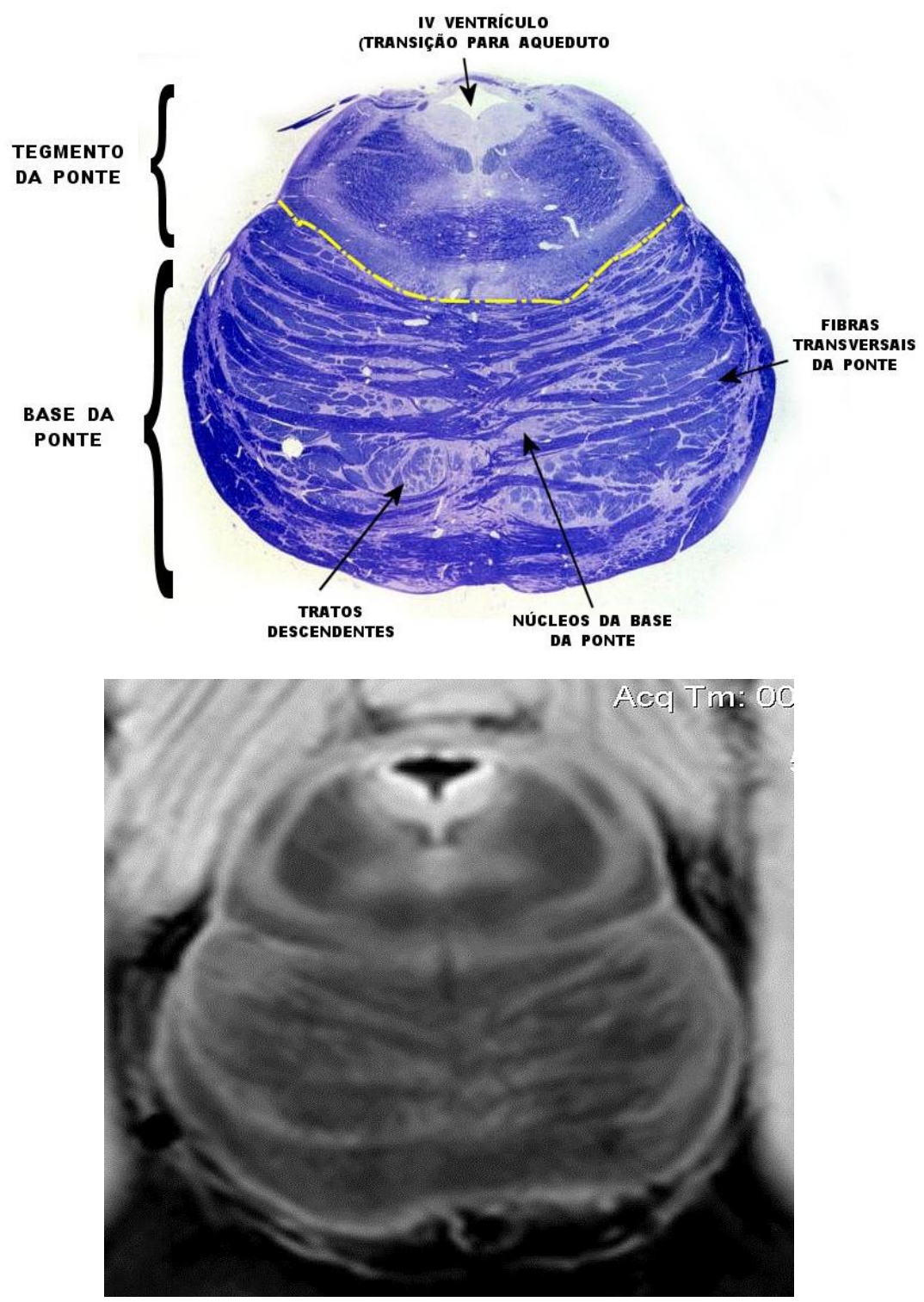

Nestas imagens da ponte, podemos observar o tegmento e base da ponte, tratos descendentes, núcleos próprios da ponte, fibras transversas, lemnisco lateral, trato espino talâmico lateral, lemnisco medial, decussação do pedúnculo cerebelar superior, pedúnculo cerebelar superior, fascículo longitudinal medial e a decussação das fibras do nervo troclear no véu medular superior. Todas as estruturas que foram visualizadas no corte histológico foram visualizadas na imagem de RM menos a do nervo troclear o qual não apareceu nos cortes de RM . 
Figura 33- Imagens de correlação entre IRM e corte histológico evidenciando detalhes do tegmento da ponte

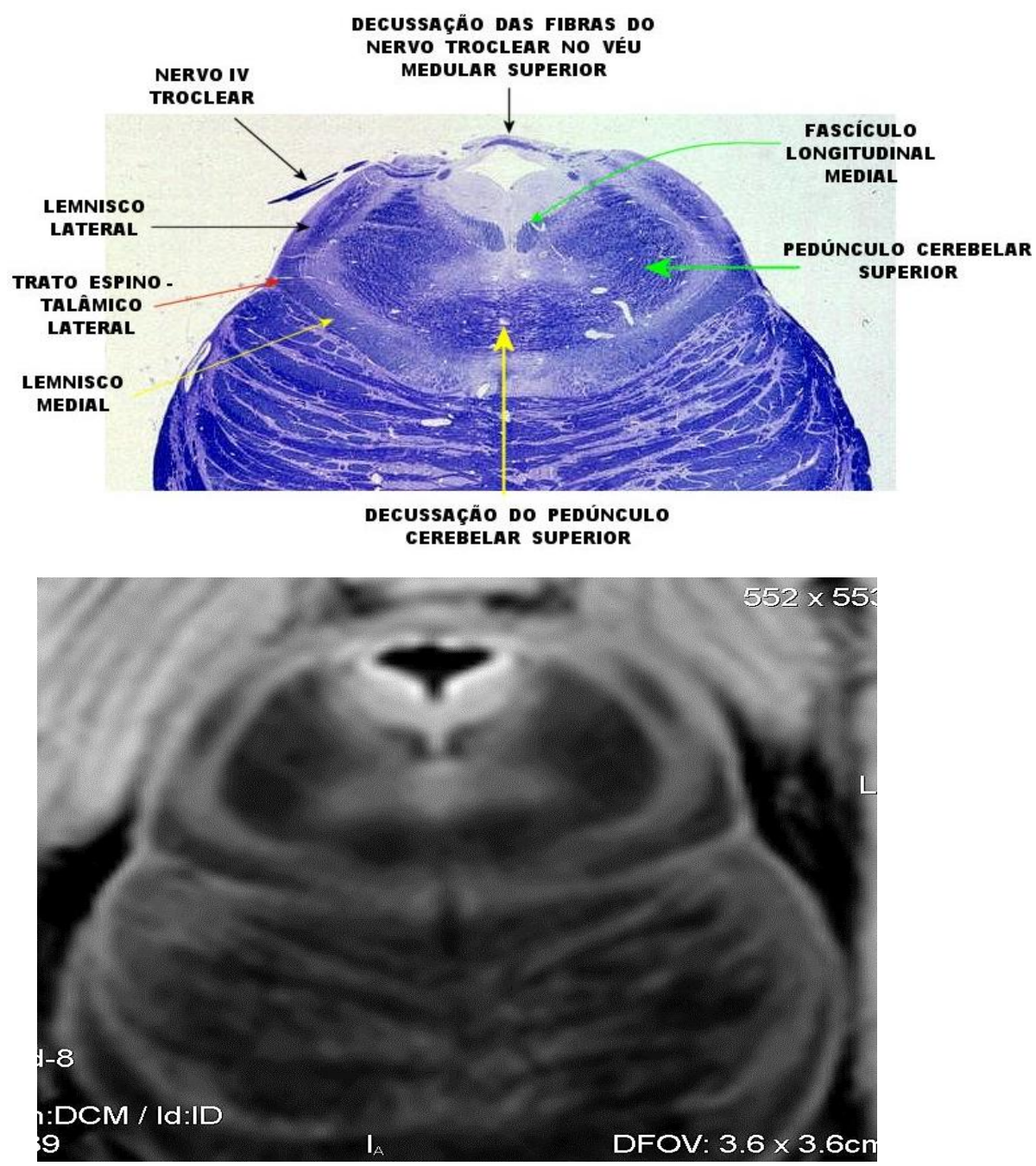


Figura 34- Imagens de correlação entre IRM e corte histológico do mesencéfalo no nível dos colículos inferiores
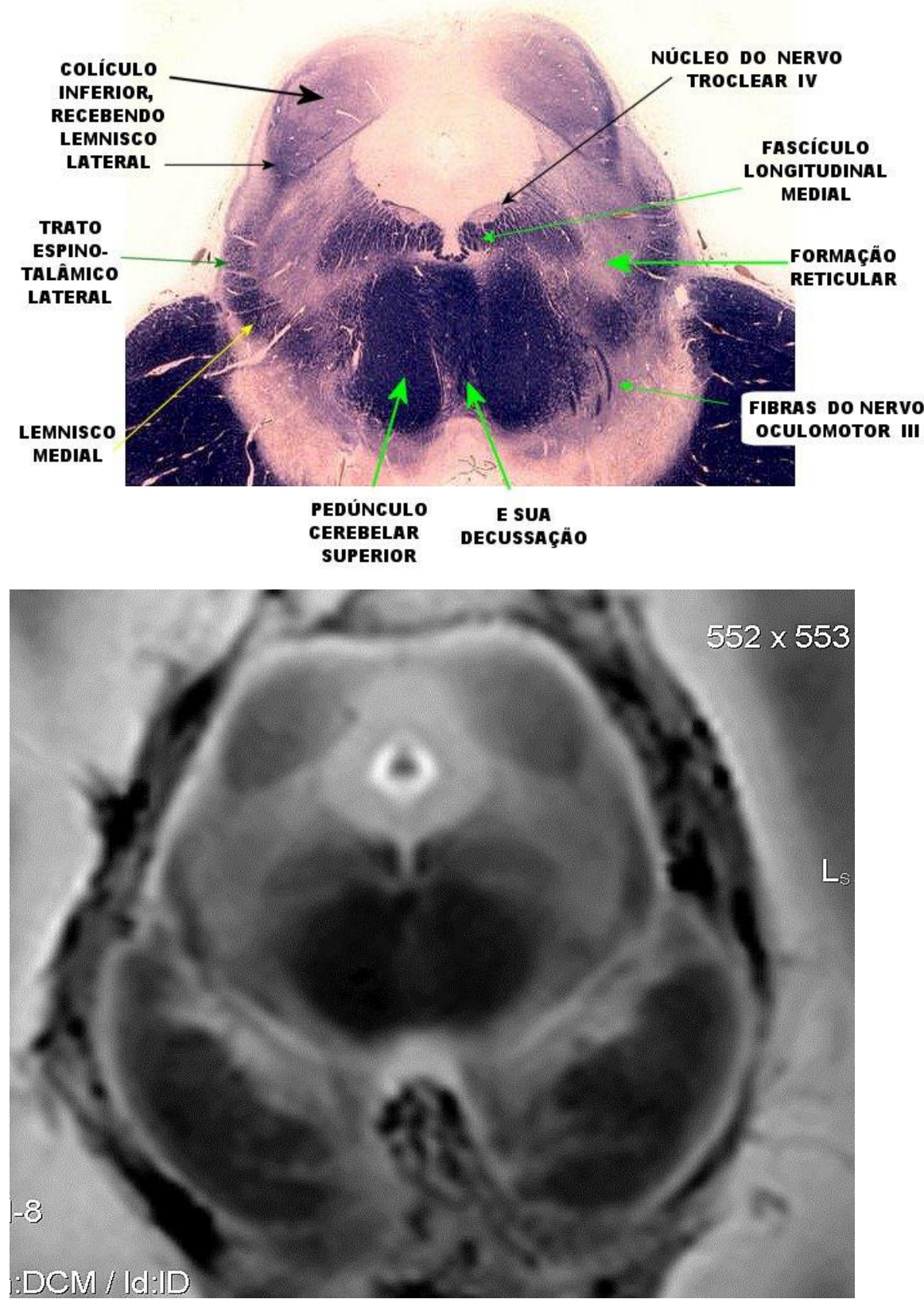

Nestas imagens, podemos observar o colículo inferior, o trato espino-talâmico lateral, o lemnisco medial, o pedúnculo cerebelar superior e sua decussação, a formação reticular, o fascículo longitudinal medial e o núcleo do nervo troclear. Todas as estruturas que foram visualizadas no corte histológico foram visualizadas na imagem de RM, menos as fibras do nervo oculomotor. 
Figura 35- Imagens de correlação entre IRM e corte histológico do mesencéfalo no nível do colículos superiores
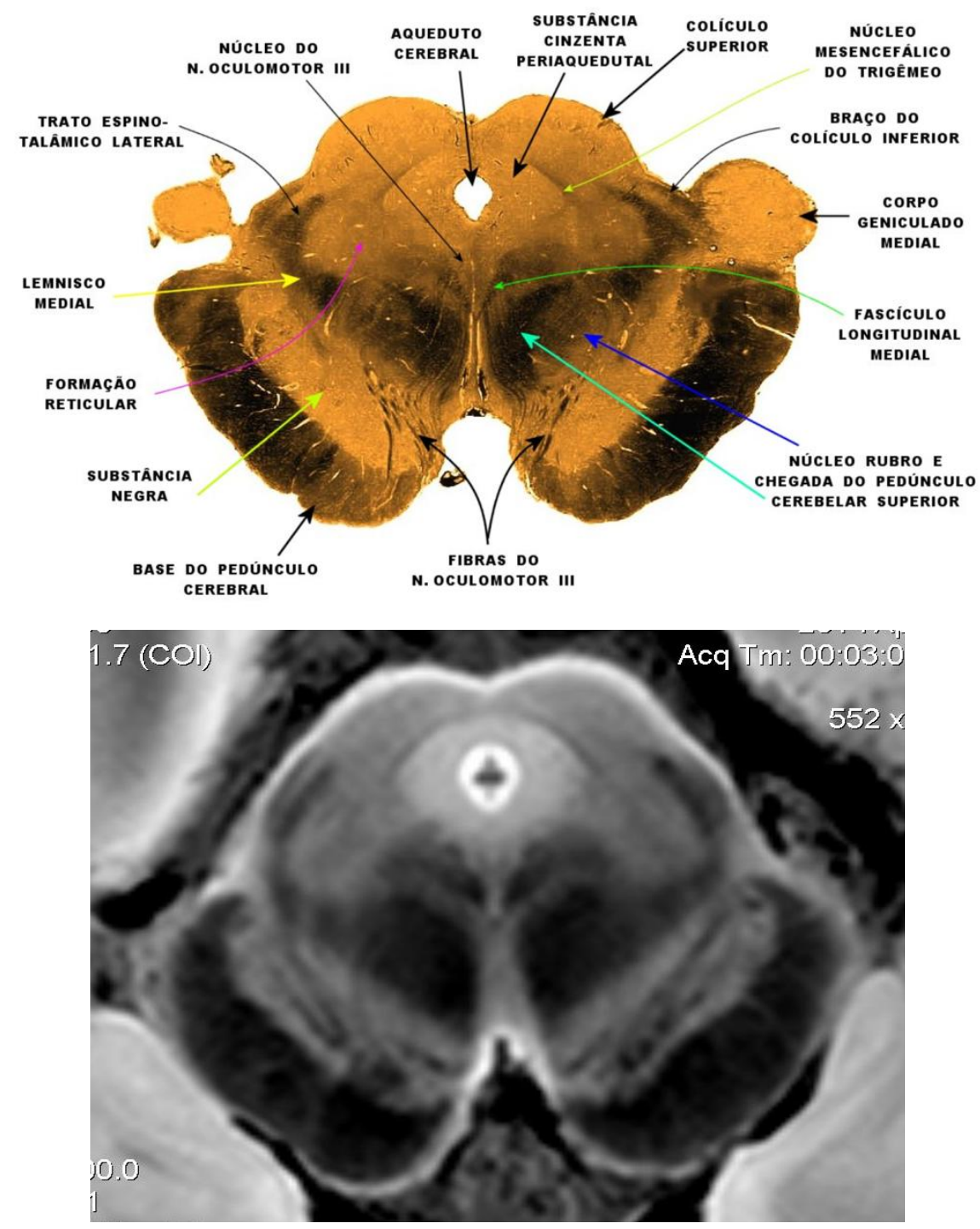

Nestas imagens do mesencéfalo, observamos o núcleo do nervo oculomotor, o trato espino-talâmico lateral, o lemnisco medial, a formação reticular, a substância negra, a base do pedúnculo cerebral, fibras do nervo oculomotor, núcleo rubro, fascículo longitudinal medial, braço do colículo inferior, núcleo mesencefálico do trigêmeo, colículo superior, substância cinzenta periaquedutal, aqueduto cerebral. Todas as estruturas que foram visualizadas no corte histológico foram visualizadas na imagem de RM. 
Figura 36- Imagens de correlação entre IRM e corte histológico na transição Mesencéfalo diencéfalo
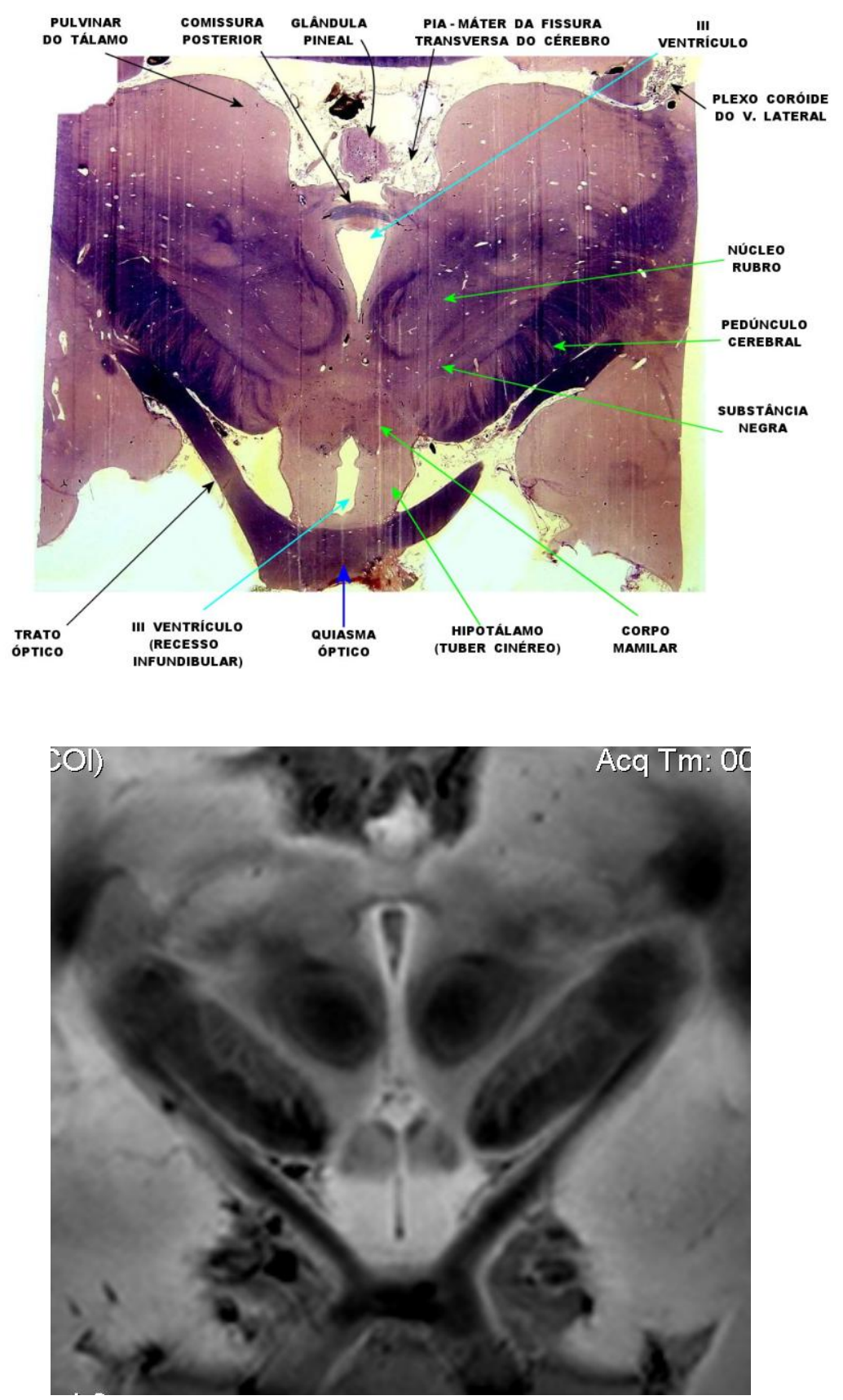

Nestas imagens da transição mesencéfalo-diencéfalo, observamos o pulvinar do tálamo, a comissura posterior, o trato e quiasma óptico, o recesse infundibular, hipotálamo (tuber cinério), corpos mamilares, substância negra, pedúnculo cerebral, núcleo rubro, III ventrículo. Todas as estruturas que foram visualizadas no corte histológico foram visualizadas na imagem de RM. 
ATLAS DE IMAGENS DE RESSONÂNCIA MAGNÉTICA DE ALTA RESOLUÇÃO DE CORTES MICROSCÓPICOS DO TRONCO ENCEFÁLICO 
Figura 37- Atlas de Imagens de Ressonância Magnética de Alta Resolução do bulbo no nível das pirâmides e núcleos do fynículo posterior

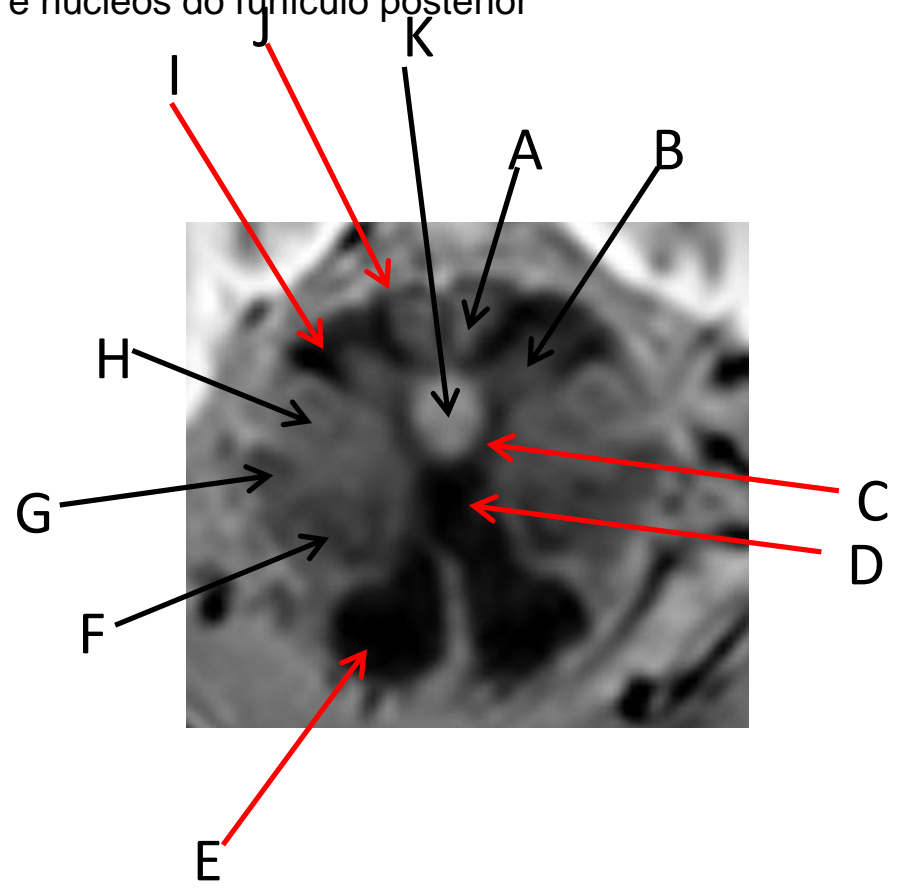

A- Núcleo grácil

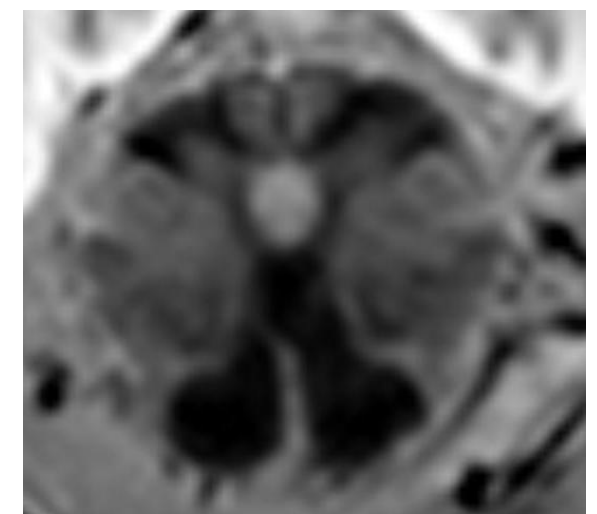

Fonte: imagens do pesquisar (2014)

B- Núcleo cuneiforme

C- Fibras arqueadas internas

D- Lemnisco medial

E- Pirâmide

F- Formação reticular

G- Trato espino-talámico lateral

$\mathrm{H}$ - Trato espinal do nervo trigêmeo

I- Fascículo cuneiforme

J- Fascículo grácil

K- Canal central 
Figura 38- Atlas de Imagens de Ressonância Magnética do bulbo de Alta Resolução no nível dos núcleos olivares inferiore $\mathbb{K}$

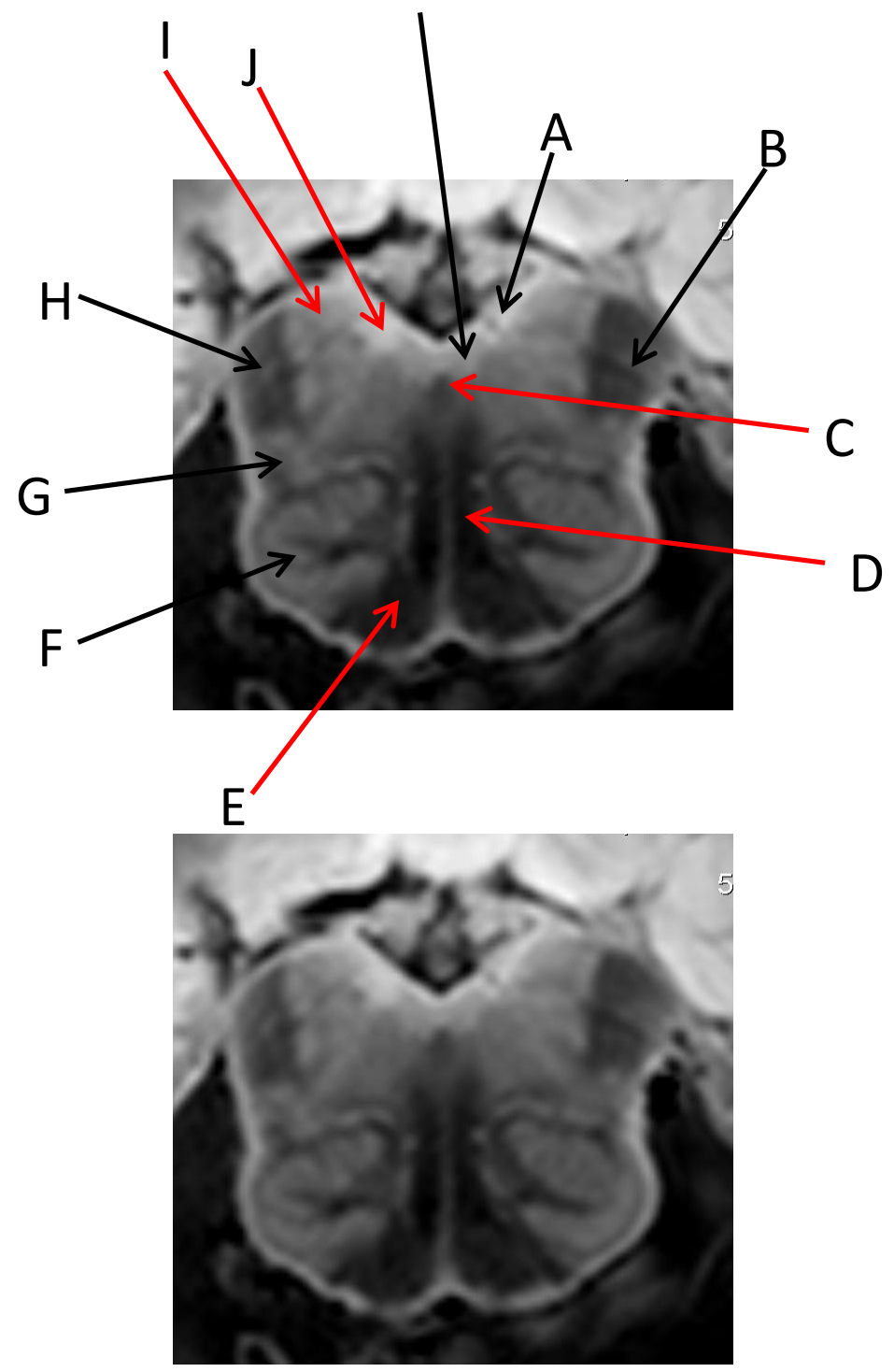

Fonte: imagens do pesquisar (2014)
A- Trato solitário e núcleo
B- Pedúnculo cerebelar inferior
C- Fascículo longitudinal medial
D- Lemnisco medial
E- Pirâmides
F- Núcleo olivar inferior
G- Trato espino-talâmico lateral
$\mathrm{H}$ - Núcleo coclear dorsal
I- Núcleo cuneiforme acessório
J- Núcleo motor dorsal do vago
K- Núcleo do hipoglosso 
Figura 39- Atlas de Imagens de Ressonância Magnética de Alta Resolução da transição

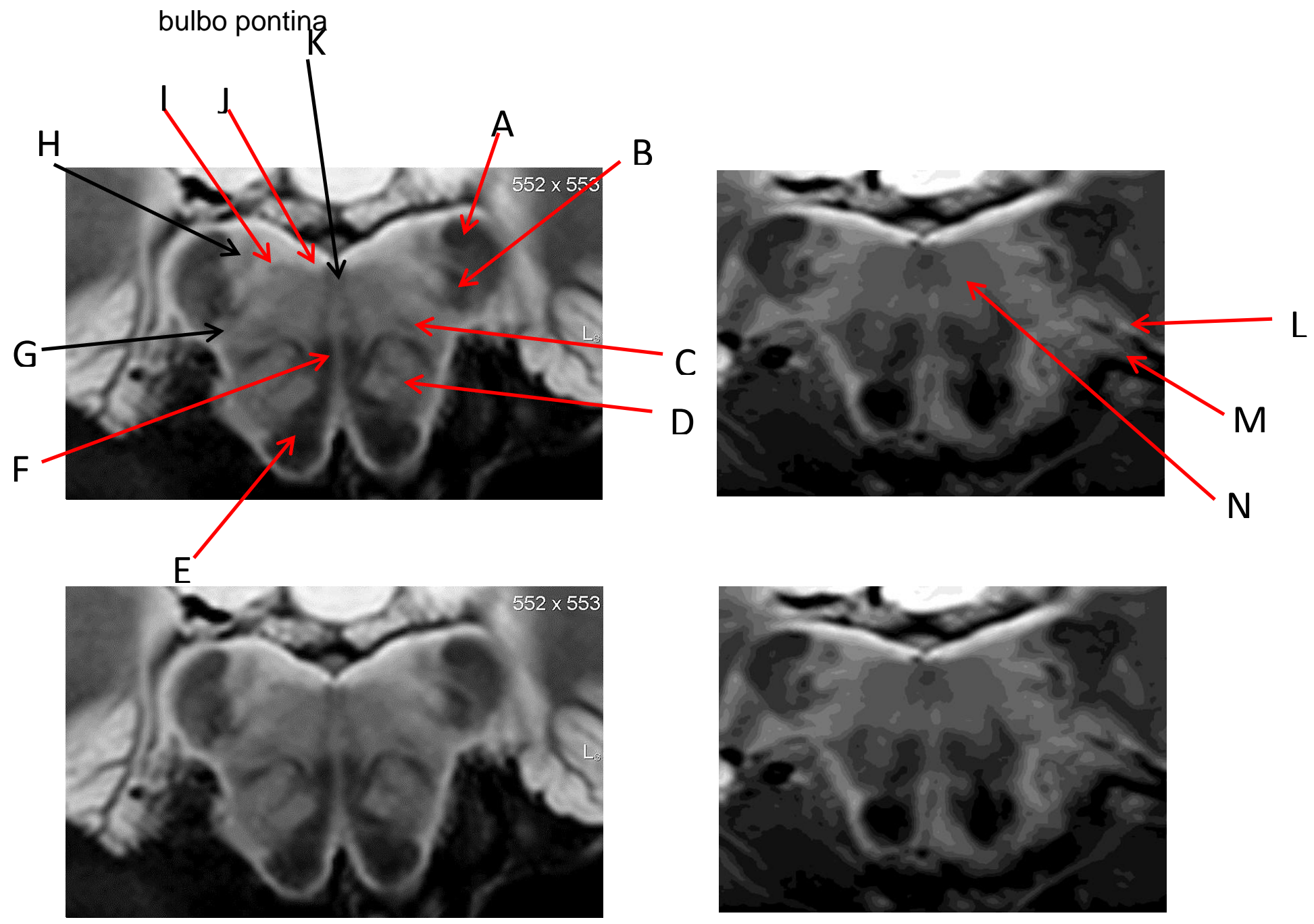

Fonte: imagens do pesquisar (2014)
A- Pedúnculo cerebelar inferior
L- Nervo Vestibulococlear
B- Núcleos vestibulares
M- Nervo Facial
C- Núcleo ambíguo
$\mathrm{N}$ - Formação reticular
D- Núcleo olivar inferior
E- Pirâmide
F- Lemnisco medial
G- Núcleo coclear ventral
H- Núcleo coclear dorsal
I- Núcleo do trato solitário
J- Núcleo do hipoglosso
$\mathrm{K}$ - Fascículo longitudinal medial 
Figura 40- Atlas de Imagens de Ressonância Magnética de Alta Resolução da Ponte, com detalhes do tegmento
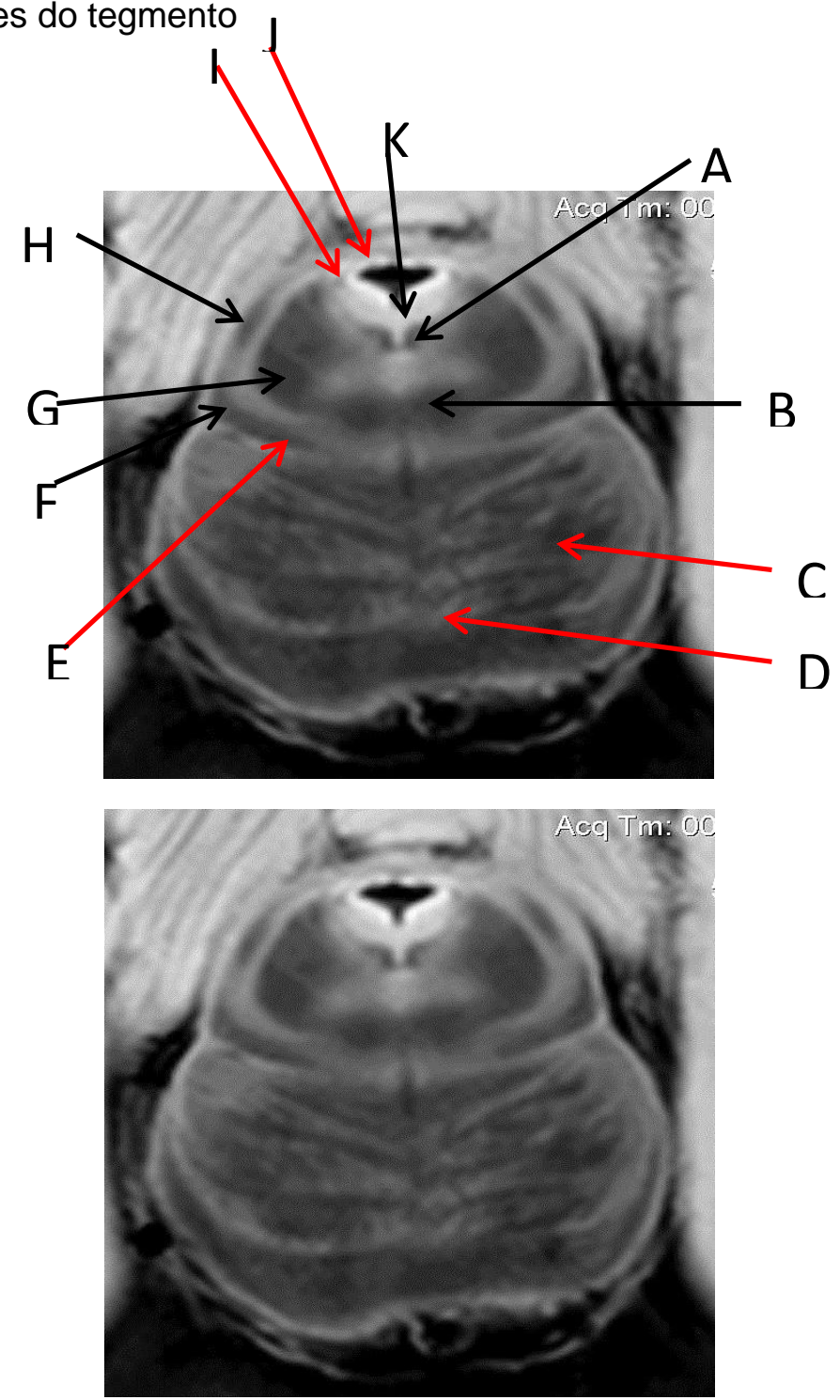

Fonte: imagens do pesquisar (2014)
A- Fascículo longitudinal medial
K- Núcleo troclear
B- Decussação do pedúnculo cerebelar superior
C- Feixes piramidais
D- Fibras pontinas transversais
E- Lemnisco medial
F- Trato espino-talámico lateral
G- Pedúnculo cerebelar superior
$\mathrm{H}$ - Lemnisco lateral
I- Nervo troclear
J- Decussação das fibras do nervo troclear no véu medular superior 
Figura 41- Atlas de Imagens de Ressonância Magnética de Alta Resolução mesencéfalo no
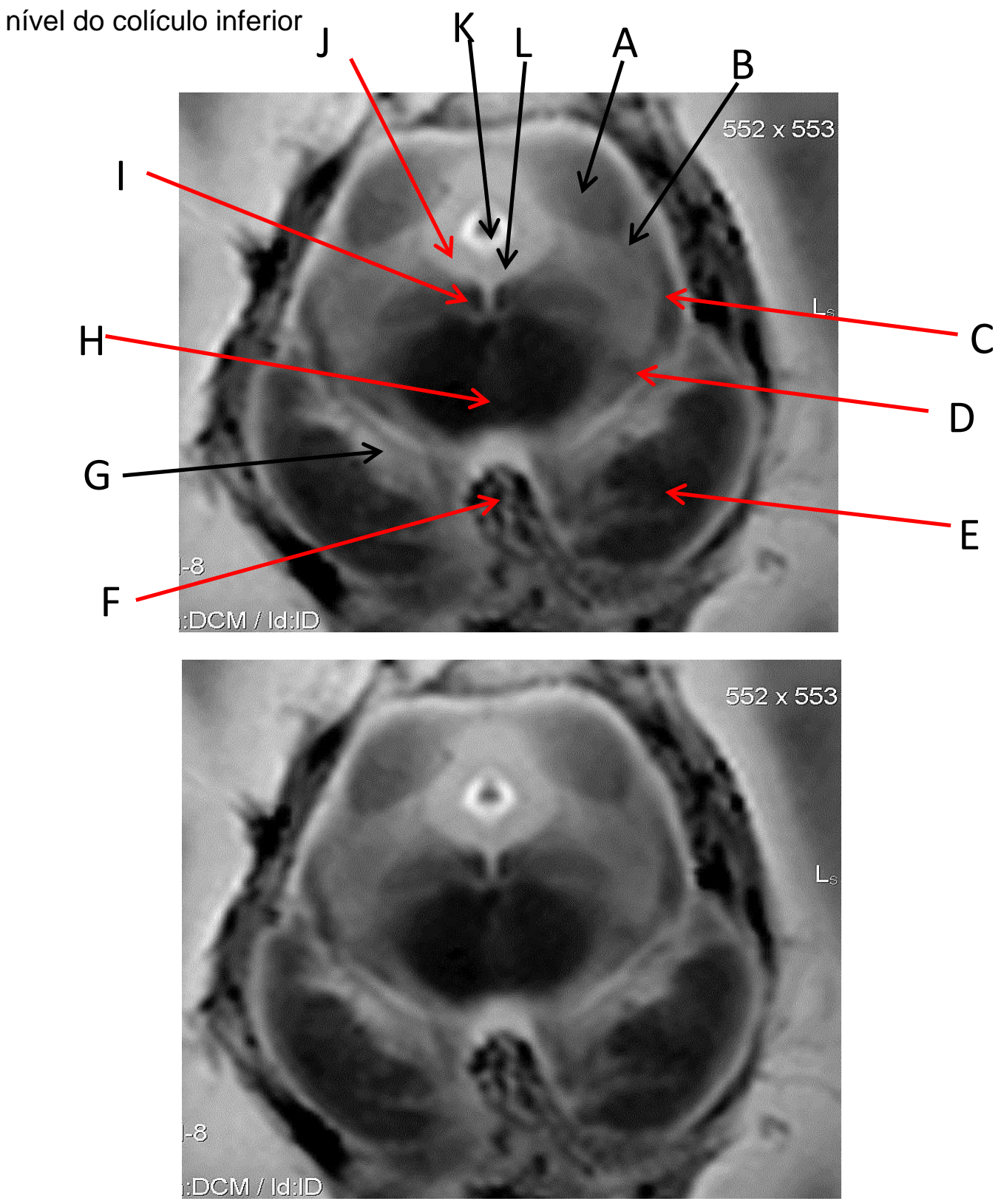

Fonte: imagens do pesquisar (2014)
A- Colículo inferior
J-Substância cinzenta periaquedutal
B- Lemnisco lateral
K- Aqueduto de Silvius
C- Trato espino-talâmico
L- Núcleo do nervo troclear
D- Leminisco medial
E- Pedúnculo cerebral
F- Fossa interpeduncular
G- Substância negra
H- Pedúnculo cerebelar superior e sua decussação
I- Fascículo longitudinal medial 
Figura 42- Atlas de Imagens de Ressonância Magnética de Alta Resolução do mesencéfalo no nível do colículo superior
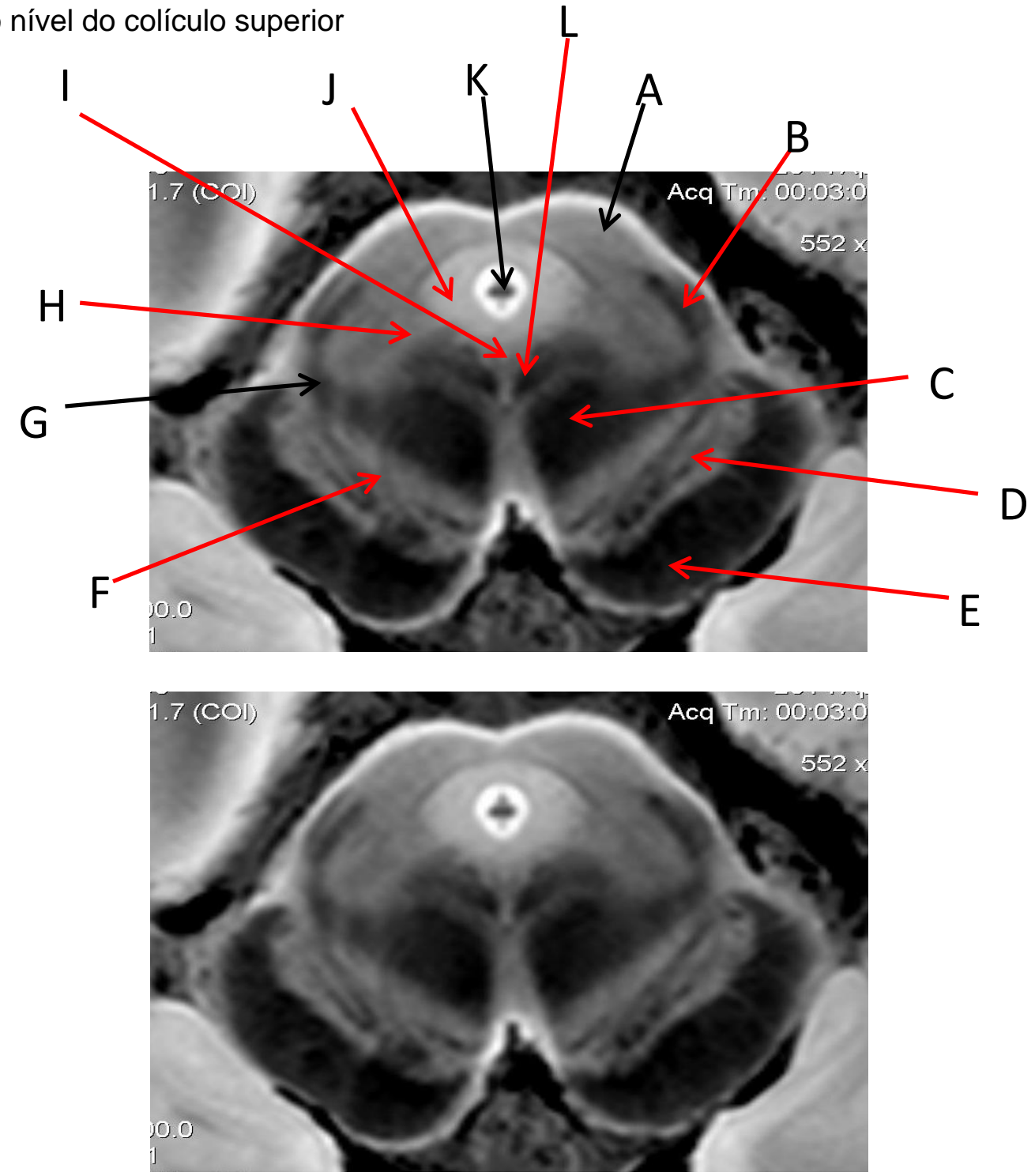

Fonte: imagens do pesquisar (2014)
A- Colículo superior
L- Fascículo longitudinal medial
B- Braço do colículo inferior
C- Núcleo rubro e chegada do pedúnculo cerebelar superior
D- Substância negra (parte reticulata)
E- Pedúnculo cerebral
F- Fibras do nervo oculomotor
G- Lemnisco medial
$\mathrm{H}$ - Formação reticular
I- Núcleo do nervo oculomotor
J- Substância cinzenta periaquedutal
K- Aqueduto de Silvius 
Figura 43- Atlas de Imagens de Ressonância Magnética de Alta Resolução na transição Mesencéfalo diencéfalo
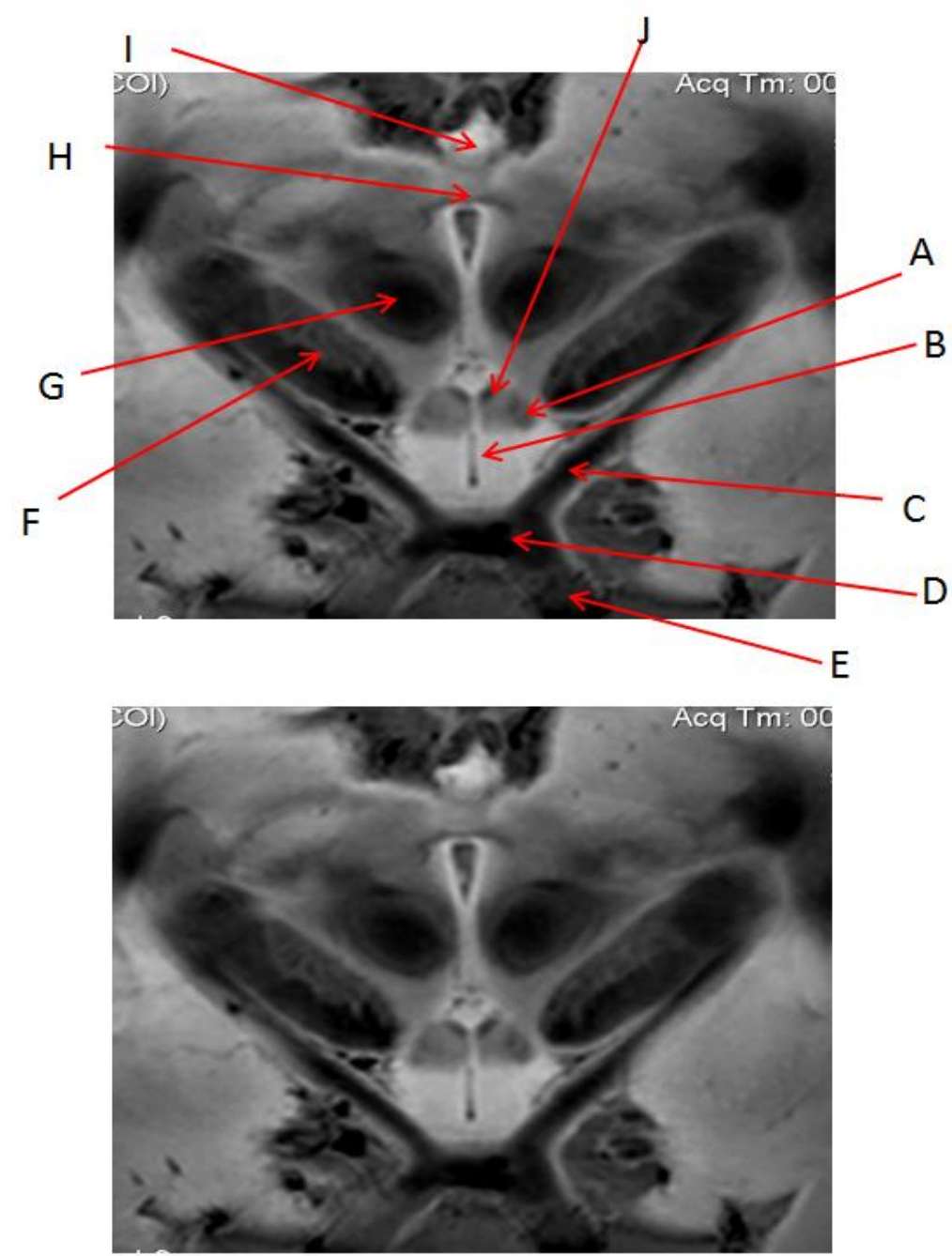

Fonte: imagens do pesquisar (2014)
A- Núcleo mamilar
G- Núcleo rubro
B- III ventrículo
$\mathrm{H}$ - Comissura posterior
C- Trato óptico
I- Pineal
D- Quiasma óptico
J- Fascículo mamilo-talâmico de Vicq d'Azyr
E- Nervo óptico
F- Pedúnculo cerebral 
Conclusão 


\section{CONCLUSÃO}

O Tronco encefálico, compreendendo o mesencéfalo, ponte e bulbo são contínuos rostralmente com o diencéfalo; e caudalmente, com a medula espinal. Embora o bulbo, a ponte e o mesencéfalo participarem em uma miríade de funções especificas, como apresentada na introdução desse trabalho, a integração desses componentes do tronco encefálico dá origem a três funções fundamentais, de forma resumida, como segue. Primeiro, o tronco encefálico é alvo ou a origem para nervos cranianos que lidam com as funções sensoriais e motoras da cabeça e pescoço. Segundo, o tronco encefálico fornece uma passagem para todos os tractos sensoriais ascendentes da medula espinal; os tractos sensoriais da cabeça e pescoço (sistema trigeminal); os tractos descendentes motores, e as vias locais ligadas a centros de movimentação dos olhos. Por fim, o tronco encefálico está envolvido na regulação do nível da consciência, através de projeções ao prosencéfalo oriundas da formação reticular. A compreensão da anatomia do tronco encefálico é essencial para o diagnóstico neurológico. As estruturas do tronco encefálico encontram-se em um espaço muito pequeno e com suprimento vascular restrito.

Desta forma, acidentes vasculares encefálicos, tumores ou doenças desmielinizantes que acometam esta região pode levar a repercussões devastadoras evoluindo com déficits funcionais, estes déficits podem ser usados para uma melhor compreensão da complexa anatomia do bulbo, da ponte e do mesencéfalo.

O diagnóstico por imagem, particularmente, exames por ressonância magnética podem levar a uma melhor compreensão desta anatomia e as patologias que o acometem. Neste trabalho, realizamos um mapeamento e uma revisão da anatomia e das função das diversas estruturas do tronco encefálico que podem ser visualizadas pelo exame de ressonância magnética com aparelho de alto campo (3 Teslas) os quais serão correlacionados com cortes macroscópicos e histológicos no mesmo nível da aquisição da imagem.

O conhecimento aprimorado da localização das diversas estruturas do tronco encefálico como lemniscos, núcleos, tratos e outras, em exames de imagem é um terreno fértil para estudos mais detalhados e precisos das diversas patologias que 
podem acometer esta região do encéfalo e torna-se uma ferramenta indispensável para o estudo da conectividade e conhecimento do funcionamento do encéfalo.

Vislumbramos ainda o futuro dos exames de alta resolução por ressonância magnética com esta resolução em vivo, chegando muito próximo da resolução microscópica, faz-se necessário que os neurorradiologistas estejam familiarizado com os aspectos histológicos das imagens por ressonância magnética.

Concluímos com o presente estudo que é possível a obtenção de imagens de ressonância magnética de alta resolução com aparelho de 3 Teslas, imagens essas só obtidas na atualidade por aparelhos de 7 teslas de valores muito elevados, existindo só um no país. Com a técnica que desenvolvemos podemos demonstrar a anatomia microscópica do tronco encefálico, ainda que em post mortem, chamando a atenção para um maior aprofundamento do conhecimento anatômico desta região por parte do neurorradiologista e neurocientistas. 


\section{REFERÊNCIAS}

ALBERSTONE, Cary D.; BENZEL, Edward C.; M. Najm Imad; P. Steinmetz, Michael. Anatomic Basis of Neurologic Diagnosis. New York. Thieme medical publishers inc. 2009.

BLOEDEL, J.R; BRACHA, V. Current concepts of climbing fiber function. Anat Rec, v.253, p. 118-126, 1998.

AFIFI, Adel. K; BERGMAN, Ronald. Functional Neuroanatomy: Text and Atlas, 2nd Edition (Lange Basic Science). : MCGRAW HILL MEDICAL, 2005.

CIRIELLO, J; CALARESU, F.R. Vagal bradycardia elicited by stimulation of the external cuneate nucleus in the cat. Am J Physiol; v. 235, n.5, nov 1978; p.286-93

CORMIER, P.J; LONG, E.R; RUSSELL, E.J. MR imaging of posterior fossa infarctions: vascular territories and clinical correlates. Radiographics, 1992; v.12, n.6, p. 1079-96. Pubmed citation.

DOUGLAS, J; GOULD, James D. Fix. BRS Neuroanatomy (Board Review Series); Fifth Edition, Lippincott Williams \& Wilkins, 2013.

HAINES, Duane E. Fundamental Neuroscience for Basic and Clinical Applications 3th Edition. Churchill Livingstone , 2006.

JACOBS D. A; GALETTA S. L. Neuro-ophthalmology for neuroradiologists. AJNR Am J Neuroradiol, v.28, n.1, p. 3-8. Pubmed citation.

KIERNAN, John A.; Rajakumar, Raj. Barr's The Human Nervous System: An Anatomical Viewpoint,Tenth edition. Lippincott Williams \& Wilkins. 2013

KOTCHABHAKD, Naiphinich. The Human Cerebral Córtex. Lecture 10 Research Center for Neuroscience, Mahidol University,Tayland, 2011.

KUMRAL, E; BAYÜLKEM, G; Evyapan, D. Clinical spectrum of pontine infarction. Clinical MRI correlations. J. Neurol., v. 249, n.12, p. 1659-70, 2002. Pubmed citation

MAEDA, T. The locus coeruleus: history. J. Chem. Neuroanat., February, v.18, n.12, p.57-64, 2000.

MORITANI, Toshio et al. Anatomy and Pathology of the Cerebellar Peduncle. Division of Diagnostic and Interventional Neuroradiology. Department of Radiology, 
University of Rochester Medical Center, Rochester NY. Neurographics Volume 2003, Issue 2, Article 1

NAIDICH, T.P; DUVERNOY, H.M; DELMAN, B.N; SORENSEN, A.G; KOLLIAS S.S; HAACKE E.M. Duvernoy's Atlas of the Human Brain Stem and Cerebellum: High-Field MRI, Surface Anatomy, Internal Structure, Vascularization and 3D Sectional Anatomy. ${ }^{\text {st }}$ Edition, Springer. 2008.

NOLTE, John.The Human Brain in Photographs and Diagrams. Fourth Edition. Elservier. 2013.

OMER, Onbas; MECIT, Kantarci; FATIH, Alper; LEYLA, Karaca. Millard Gluber MR finding. January, v. 47, Issue 1,p.35-37, 2005.

POPESCU, B.F.G; LENNON, V.A; PARISI J. E; et al. Neuromyelitis optica unique area postrema lesions: Nausea, vomiting, and pathogenic implications. Neurology, v. 76, p.1229-1237, 2011.

PURVES, Dale et al., Neuroscience 4Th edition. Sunderland, MA ,USA: Sinauer associates, 2008

SNELL, Richard S. Clinical Neuroanatomy. Lippincott Williams \& Wilkins, Seventh Edition edition January , 2009.

SITE DIDÁTICO DE ANATOMIA PAT., NEUROPATOLOGIA E NEUROIMAGEM (2015). Disponível em:< http://anatpat.unicamp.br/neupimportal.html>. Acesso em: 20 mar.2015

YOSHINAGA, T; NAKAMURA, K; KANEKO, K; NAKAMURA, A. A Case Report of WEBINO Syndrome with Convergence Impairment. J.Neurol Neurophysiol, v. 6 , n.270, p.4172/2155-9562, 2015.

TALIH, F. R. Assistant Professor of Psychiatry at the Department of Psychiatry of the American University of Beirut Medical Center, Beirut, Lebanon. Innov Clin Neurosci, v. 10, n.5-6, p. 28-31, 2013.

THE NATIONAL ACADEMIES. Una ventana abierta a la curación de la mente y el cuerpo: el desarrollo de la resonancia magnética. 2015. Disponível em: <http://www7.nationalacademies.org/spanishbeyonddiscovery/El\%20desarrollo\%20d e\%20la\%20resonancia\%20magn\%C3\%A9tica.html>. Acesso em: 20 fev. 2016.

URBAN, Peter P; CAPLAN, Loui R. Brainstem Disorderes. 2011. p.189-349. 
WHAT-WHEN-HOW. Overview of the Central Nervous System (Gross Anatomy of the Brain) Part 2. Disponível em: <http://what-whenhow.com/neuroscience/development-of-the-nervous-system-gross-anatomy-of-thebrain-part-2/)>. Acesso em: 20 abr. 2015. 
$\mathbf{A}_{\mathrm{NeXOS}}$ 
Projeto de pesquisa: "Quantificação de deposição de ferro no cérebro usando ressonância magnética"

Pesquisadores responsáveis: Jeam Haroldo Oliveira Barbosa e Prof. Dr. Carlos Ernesto Guarrido Salmon

Instituição Proponente: Faculdade de Filosofia, Ciências e Letras de Ribeirão Preto - USP.

"O CEP do HC e da FMRP-USP concorda com o parecer ético emitido pelo CEP da Instituição Proponente, que cumpre as Resoluções Éticas Brasileiras, em especial a Resolução CNS 196/96. Diante disso, o HCFMRP-USP, como instituição co-participante do referido projeto de pesquisa, está ciente de suas co-responsabilidades e de seu compromisso no resguardo da segurança e bemestar dos sujeitos desta pesquisa, dispondo de infra-estrutura necessária para a garantia de tal segurança e bem-estar".

Ciente e de acordo:
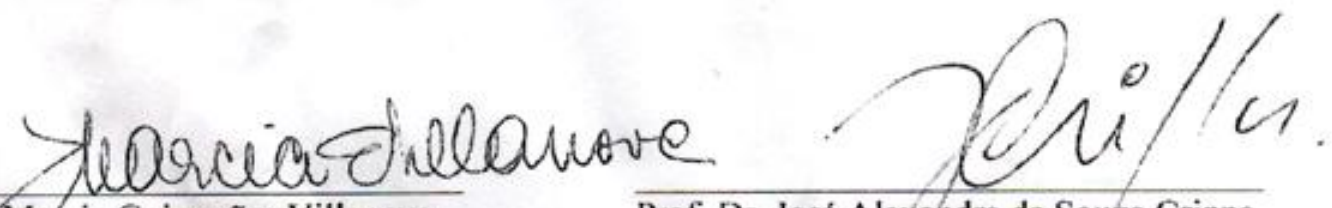

Dy.1 Marcia Guimarães Villanova Coordenadora do Comitê de Ética em Pesquisa - HCFMRP-USP
Prof. Dr. José Alexandre de Souza Crippa Coordenador Técríco Científico da Unidade de Pesquisa Clińica - HCFMRP-USP
Campus Universitário - Monte Alegre 14048-900 Ribeiráo Preto SP
Comitẽ de Etica em Pesquisa do HCRP e FMRP-USP FWA-00002733; IRB-00002186 e Registro SISNEP/CONEP $n^{\circ} 4$ (016) $3602-2228$ cep@hcrp.usp.br 


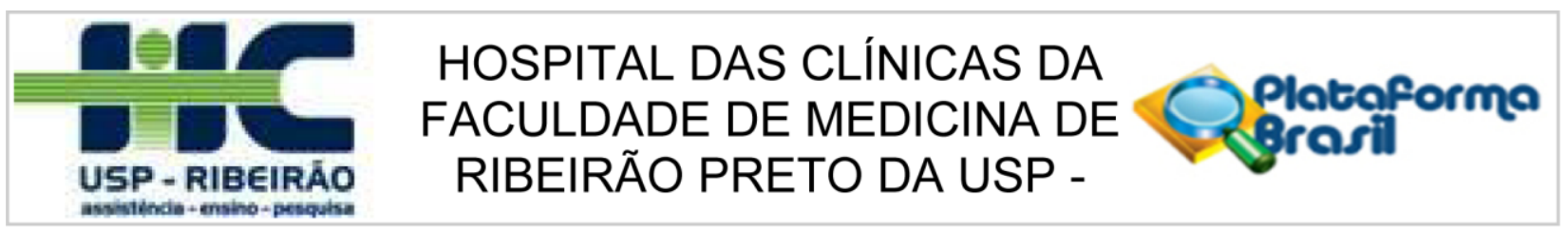

\section{PARECER CONSUBSTANCIADO DO CEP}

\section{Elaborado pela Instituição Coparticipante}

\section{DADOS DO PROJETO DE PESQUISA}

Título da Pesquisa: Validação da quantificação de íons paramagnéticos no cérebro por imagem de Ressonância Magnética

Pesquisador: Jeam Haroldo Oliveira Barbosa

Área Temática:

Versão: 2

CAAE: 20855413.2.3001.5440

Instituição Proponente: Faculdade de Filosofia, Ciências e Letras de Ribeirão Preto- USP

Patrocinador Principal: CONS NAC DE DESENVOLVIMENTO CIENTIFICO E TECNOLOGICO

FUNDACAO DE AMPARO A PESQUISA DO ESTADO DE SAO PAULO

\section{DADOS DO PARECER}

Número do Parecer: 808.795

Data da Relatoria: $23 / 01 / 2014$

Apresentação do Projeto:

De acordo com o parecer da Instituição Proponente.

Objetivo da Pesquisa:

De acordo com o parecer da Instituição Proponente.

Avaliação dos Riscos e Benefícios:

De acordo com o parecer da Instituição Proponente.

Comentários e Considerações sobre a Pesquisa:

De acordo com o parecer da Instituição Proponente.

Considerações sobre os Termos de apresentação obrigatória:

Apresentou carta de anuência dos responsáveis pelos locais de coleta no HCFMR-USP.

\section{Recomendações:}

Não há.

Endereço: CAMPUS UNIVERSITÁRIO

Bairro: MONTE ALEGRE CEP: $14.048-900$

UF: SP Município: RIBEIRAO PRETO

Telefone: (16)3602-2228 Fax: (16)3633-1144 E-mail: cep@hcrp.usp.br 


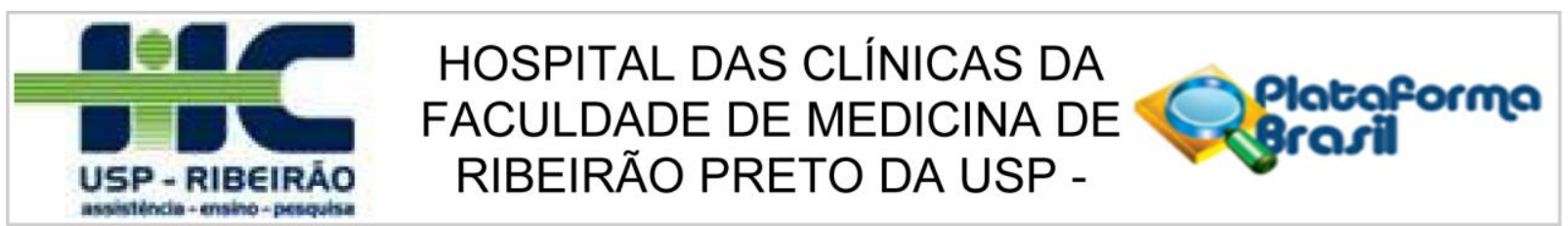

Continuação do Parecer: 808.795

Conclusões ou Pendências e Lista de Inadequações:

O CEP tomou ciência e concorda com o parecer da Instituição Proponente.

\section{Situação do Parecer:}

Aprovado

Necessita Apreciação da CONEP:

Não

\section{Considerações Finais a critério do CEP:}

"O CEP do HC e da FMRP-USP concorda com o parecer ético emitido pelo CEP da Instituição Proponente, que cumpre as Resoluções Éticas Brasileiras, em especial a Resolução CNS 466/12. Diante disso, o HCFMRP-USP, como instituição co-participante do referido projeto de pesquisa, está ciente de suas coresponsabilidades e de seu compromisso no resguardo da segurança e bem-estar dos sujeitos desta pesquisa, dispondo de infra-estrutura necessária para a garantia de tal segurança e bem-estar".

RIBEIRAO PRETO, 26 de Setembro de 2014

Assinado por:
MARCIA GUIMARÃES VILLANOVA
(Coordenador)

Endereço: CAMPUS UNIVERSITÁRIO

$\begin{array}{lll}\text { Bairro: } & \text { MONTE ALEGRE } & \text { CEP: } \\ \text { UF: SP } & \text { Municipio: } & \text { RIBEIRAO PRETO }\end{array}$

Telefone: (16)3602-2228 Fax: (16)3633-1144 E-mail: cep@hcrp.usp.br 
